Buku kimia pangan ini berisi pengetahuan dasar tentang jenis ikatan, reaksi kimia yang terjadi pada bahan pangan, komponen pangan meliputi karbohidrat, lemak dan minyak, air, protein dan enzim serta penyusunnya.

Buku ini sangat cocok sebagai pegangan bagi mahasiswa teknologi pangan dan pemerhati pangan pada umumnya.

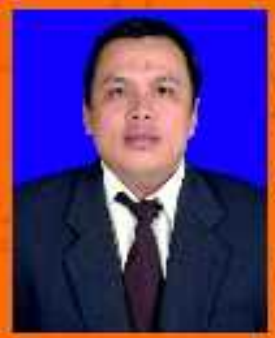

Mulono Apriyanto, lahir di Yopyokarta 27 April 1971. We yyelessikan pendidikan SD dan S.MA di Yogyakarta. secangkan pendidikan SMP di lember latim. Vicanjutan studl S-1 di Institut Pertanian STIPER Yosyaliarta, Setelah lulus dari Instiper, ia bekerja di perkcbuner kclapa sawit h 1ngga 2003 , kenudian meriadi s.al pengaja di Politekrik Pertanian di Temoilahan. Melanjutkan pendidikan Program Pascasarjana S-2 Teknologi Has I Perkebuna 7- FTP LCM lulus tahun 2007. la kemudian mclanjutkan pendidikan Doktoral $11 m \perp$ Pangan-FTP UCM, lulus Juli 2016. Penu is altit di lembaga Mitra Mand ri Indonesia (LMMil) di Yagyakarta, łıge sebagaipemateridi beberapalembaga pendidikan.

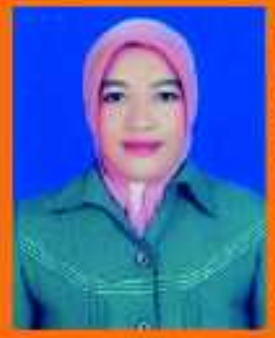

Rujiah, lahir di Hidayat, 27 Agustus 1983 Menyelesaikan pendidikan SD di Fidayat, selanjutnya SMP sampat SMA di Tentilahan, Indragiri Hilir. Melanyutkan pendidikan 5. Studi Teknologi Pangan di Unipersitas Islam Indragifi (UNISI) Tembilahan. Ia meniti karier bekerja pada bidang ketaharan pangan sejak 2C10hingrasekarang.

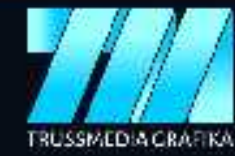

1. Dongkelan No. 55 \% K apwak K.lon

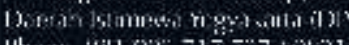

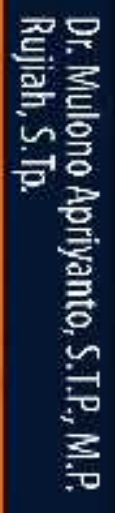

\section{Dr. Mulono Apriyanto, S.T.P., M.P.}

Rujiah, S.Tp.
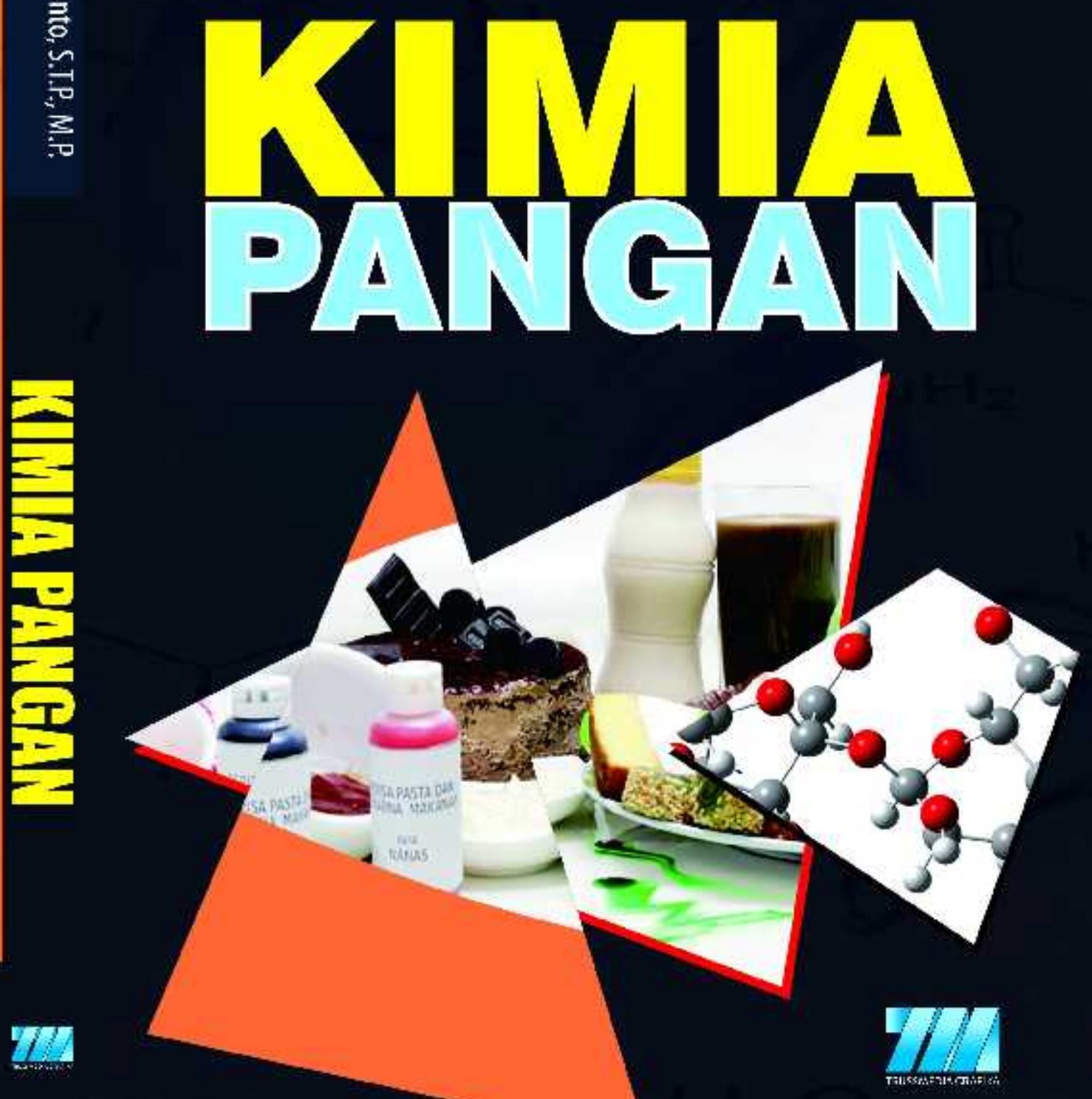


\section{ฟ \\ PERPUSTAKAAN NASIONAL \\ REPUBLIK INDONESIA}

Apabila buku sudah diterbitkan harap diserahkan setiap judul 2 eksemplar ke Perpustakaan Nasional RI dan 1 eksemplar ke Perpustakaan Daerah di ibukota propinsi dimana buku diterbitkan sesuai Undang-Undang Nomor 4 Tahun 1990 tentang Serah-Simpan Karya Cetak Dan Karya Rekam (Pasal 2)

Alamat pengiriman buku:

Perpustakaan Nasional RI

Direktorat Deposit Bahan Pustaka

Subdirektorat Deposit

Gedung E Lt.7

Jl. Salemba Raya 28A Kotak Pos 3624

Jakarta 10002 - Indonesia

Terima kasih atas partisipasi anda dalam mewujudkan Koleksi Deposit Bahan Pustaka Indonesia

UNDANG-UNDANG NOMOR 4 TAHUN 1990 TENTANG SERAH-SIMPAN KARYA CETAK DAN KARYA REKAM

BAB II

KEWAJIBAN SERAH - SIMPAN KARYA CETAK DAN KARYA REKAM

Pasal 2

Setiap penerbit yang berada di wilayah negara Republik Indonesia, wajib menyerahkan 2 (dua) buah cetakan dari setiap judul karya cetak yang dihasilkan kepada Perpustakaan Nasional, dan sebuah kepada Perpustakaan Daerah di ibukota propinsi yang bersangkutan selambat-lambatnya 3 (tiga) bulan setelah diterbitkan. 


\section{KIMIA PANGAN}




\section{all rights reserved}

\section{Hak Cipta dilindungi Undang-Undang}

\section{Sanksi Pelanggaran Pasal 72 \\ Undang-Undang Nomor 19 Tahun 2002}

1. Barangsiapa dengan sengaja dan tanpa hak melakukan perbuatan sebagaimana dimaksud dalam pasal 2 ayat (1) atau pasal 49 ayat (1) dan ayat (2) dipidana penjara paling singkat 1 (satu) bulan dan/atau denda paling sedikit Rp1.000.000,00- (satu juta rupiah) atau paling lama 7 (tujuh) tahun dan/atau denda paling banyak Rp 5.000.000.000,00 (lima miliar rupiah)

2. Barangsiapa dengan sengaja menyiarkan, memamerkan, mengedarkan, atau menjual kepada umum suatu ciptaan dan barang hasil pelanggaran hak cipta atau hak terkait, sebagaimana dimaksud ayat (1) dipidana dengan pidana paling lama 5 (lima) tahun dan/atau denda paling banyak Rp 500.000.000,00 (lima ratus juta rupiah) 


\section{KIMIA PANGAN}

Dr. Mulono Apriyanto, S.I.P., M.P.

Rujiah, S.Tp.

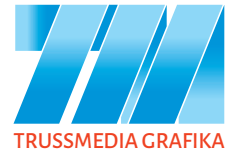


Copyright (C) 2017, Mulono Apriyanto \& Rujiah

Hak cipta dilindungi oleh undang-undang.

Dilarang memproduksi atau memperbanyak seluruh atau sebagian dari buku ini dalam bentuk atau cara apa pun tanpa izin dari penulis dan penerbit

\title{
KIMIA PANGAN
}

\author{
Penulis: \\ Dr. Mulono Apriyanto, S.T.P., M.P. \\ Rujiah, S.Tp. \\ Editor/ Penyunting: \\ Minan Nuri Rohman \\ Cover: \\ Wakhyudin \\ Layout: \\ St. Navisah \\ Penerbit: \\ Trussmedia Grafika \\ Jl. Dongkelan No. 357 Krapyak Kulon, \\ Daerah Istimewa Yogyakarta (DIY) \\ Phone. 081903717 727/0857 29188825 \\ Email: one_trussmedia@yahoo.com \\ www.trussmediagrafika.com
}

Cetakan I, Maret 2017

xii $+172 ; 14 \times 20,5 \mathrm{~cm}$

ISBN: 978-602-0992-69-3 


\section{KATR PENGANTAR}

Puji dan syukurpenulis panjatkan ke hadirat Tuhan YangMaha Kuasa atas segala berkat dan karunia-Nya sehingga penulisan buku ini dapat diselesaikan. Dalam rangka memperkaya pengetahuan mengenai kimia pangan bagi mahasiswa dan pemerhati pangan, maka penulis menghadirkan satu buku pegangan tentang kimia pangan.

Buku Kimia pangan ini berisi pengetahuan dasar tentang jenis ikatan, reaksi kimia yang terjadi pada bahan pangan, komponen pangan meliputi karbohidrat, lemak dan minyak, air, protein dan enzim serta penyusunnya. Oleh karena itu, buku kimia pangan ini sangat cocok sebagai pegangan bagi mahasiswa teknologi pangan dan pemerhati pangan.

Kepada semua pihak yang telah memberikan kontribusi dan bantuannya untuk terbitnya buku ini disampaikan terima kasih.

Tembilahan, Februari 2017

Penulis 



\section{DAFTAR IS}

KATA PENGANTAR V

DAFTAR ISI VII

\section{BAB I}

\section{DASAR IKATAN DAN REAKSI KIMIA 1}

1.1. TEORI ATOM 1

1.2. IKATAN KIMIA $~ 4$

1.3. REAKSI KIMIA 15

1.4. OKSIDASI DAN REDUKSI 18

1.5. GUGUS FUNGSIONAL 19

\section{BAB |I}

\section{AIR DAN LARUTAN 25}

2.1. AIR 25

2.1.1. STRUKTUR MOLEKUL AIR 26

2.1.2. IKATAN AIR 27

2.1.3. SIFAT AIR 28

2.1.4. DISOSIASI AIR 30 
2.2. LARUTAN 33

2.2.1. JENIS LARUTAN 33

2.2.2. KONSENTRASI $~ 36$

2.2.3. SIFAT KIMIA LARUTAN 38

\section{BAB III}

\section{PROTEIN 47}

3.1. ASAM AMINO 48

3.2. PEPTIDA 54

3.3. PROTEIN $~ 56$

3.3.1. KLASIFIKASI PROTEIN $~ 56$

3.3.2. STRUKTUR PROTEIN $\sim 59$

3.3.3. IKATAN PADA PROTEIN 64

3.4. SIFAT KIMIA PROTEIN 67

3.4.1. AMFOTER 67

3.4.2. PENGIKATAN ION $~ 68$

3.4.3. HIDRASI PROTEIN $\sim 68$

3.4.4. REAKSI PEWARNAAN 69

3.4.5. HIDROLISA 71

3.4.6. OKSIDASI - REDUKSI $\sim 72$

3.4.7. SIFAT KOLOID 72

3.4.8. SIFAT SENSORIS 74

3.5. DENATURASI 75

\section{BAB IV}

ENZIM DAN KINETIKA ENZIM $\sim 77$

4.1. ENZIM 77 
4.1.1. TATA NAMA ENZIM 77

4.1.2. STRUKTUR ENZIM 78

4.1.3. KLASIFIKASI ENZIM 81

4.2. KINETIKA ENZIM 84

4.2.1. KECEPATAN REAKSI $~ 85$

4.2.2. ENERGI AKTIVASI $~ 85$

4.2.3. PENGARUH SUHU $~ 88$

4.2.4. PENGARUH PH 89

4.2.5. KONSENTRASI ENZIM 90

4.2.6. KONSENTRASI SUBSTRAT $~ 91$

4.2.7. PENGARUH KANDUNGAN AIR 91

\section{BAB V}

\section{KARBOHIDRAT 93}

5.1. MONOSAKARIDA 95

5.1.1. STRUKTUR MONOSAKARIDA 96

5.1.2. SIFAT FISIS MONOSAKARIDA 102

5.1.3. SIFAT REAKSI MONOSAKARIDA 103

5.2. OLIGOSAKARIDA 106

5.2.1. DISAKARIDA 106

5.2.2. TRISAKARIDA $\sim 107$

5.2.3. TETRASAKARIDA 108

5.3. POLISAKARIDA 108

5.3.1. HOMOPOLISAKARIDA 109

3.3.2. HETEROPOLISAKARIDA $\sim 113$

3.3.3. POLISAKARIDA MAJEMUK 115 


\section{BAB VI}

\section{LIPIDA 117}

6.1. KLASIFIKASI 118

6.1.1. LIPIDA SEDERHANA 118

6.1.2. LIPIDA CAMPURAN $\sim 119$

6.1.3. DERIVAT LIPIDA 120

6.2. ASAM LEMAK 120

6.2.1. TATA NAMA 121

6.2.2. ASAM LEMAK JENUH $\sim 121$

6.2.3. ASAM LEMAK TIDAK JENUH $\sim 125$

6.2.4. ASAM LEMAK SIKLIS, BERCABANG, TERSUBSTITUSI 126

6.2.5. ISOMERISASI $\sim 127$

6.3. LEMAK DAN MINYAK 130

6.3.1. KOMPOSISI $\sim 130$

6.3.2. SIFAT FISIS 131

6.3.3. HIDROLISA 132

6.3.4. OKSIDASI 134

6.4. WAXES 142

6.5. FOSFOLIPIDA 143

6.5.1. LESITIN $\sim 144$

6.5.2. SEFALIN 145

6.5.3. PLASMALOGEN $\sim 146$

6.6. STEROL ( STEROID ) 146 


\section{BAB VII}

\section{REAKSI PENCOKLATAN 147}

7.1. PENCOKLATAN NON ENSIMATIS 148

7.1.1. REAKSI MAILLARD 149

7.1.2. OKSIDASI ASAM ASKORBAT 155

7.1.3. KARAMELISASI $\sim 156$

7.1.4. EFEK FAKTOR LINGKUNGAN 157

7.2. PENCOKLATAN ENSIMATIS 162

7.2.1. MEKANISME 163

7.2.2. PENCEGAHAN PENCOKLATAN ENSIMATIS 165

DAFTAR PUSTAKA 171 



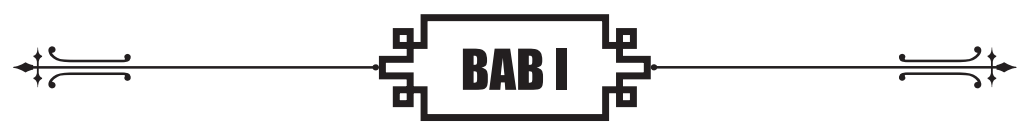

\section{DHSAR IKHTHN DAN REAKSI KIMIH}

\subsection{TEORI ATOM}

Teori-teori tentang atom, sebagai berikut:

Democritus (400 SM): benda tersusun dari partikel yang sangat kecil disebut atom.

- Dalton (1808, Bapak atom): atom berupa partikel yang tidak dapat dipecah lagi, dan atom sejenis mempunyai sifat yang sama.

. J.J. Thomson (1900): atom adalah bola padat bermuatan positif yang di dalamnya tersebar eletron bermuatan negatif.

- Rutherford (1911): atom adalah bola berongga dengan inti (+) dan dikeliingi $\mathrm{e}^{-}(-)$.

- Niels Bohr (1913, memperbaiki teori Rutherford): elektron berada pada tingkat energi tertentu.

Werener Heisenberg de Broglie (1926): berdasarkan mekanika gelombang mengatakan bahwa letak elektron tidak dapat dipastikan melainkan merupakan kebolehjadian. 
Pembahasan selanjutnya tentang teori atom didasarkan pada teori Niels Bohr, yaitu atom berupa bola dengan inti atom berada di psatnya dan dikelilingi oleh lintasan-lintasan elektron. Dalam hal ini masing-masing lintasan elektron memiliki tingkat energi tertentu yang diberi lambang "E" dan nomor lintasannya sebagai "nomor indeks", dimana $E_{1}<E_{2}<E_{3}$. Makin jauh lintasan elektron dari intinya berarti tingkat energinya makin besar. Lintasan-lintasan elektron ini dikenal sebagai "kulit atom".

Pokok-pokok teori atom Bohr, adalah sebagai berikut.

1. Elektron dalam atom bergerak pada lintasan tertentu dengan energi tertentu.

2. Elektron selama bergerak tidak memancarkan atau menyerap energi, jadi dalam keadaan stasioner.

3. Elektron jika diberi energi akan pindah ke tingkat energi yang lebih tinggi, elektron yang demikian ini disebut tereksitasi.

4. Elektron tereksitasi ini akan melepaskan energi sebesar energi yang diserap dan elektron tersebut akan kembali ke keadaan stasioner.

Pada atom yang mempunyai banyak elektron akan terjadi pemisahan elektron ke dalam sub- kulit, yang terdiri dari subkulitsubkulit s, p, d, f. Hal ini dikenal sebagai "efek Stark". Masingmasing subkulit mempunyai jumlah atom terbatas, yaitu: $s \leq 2$ elektron, $\mathrm{p} \leq 6$ elektron, $\mathrm{d} \leq 10$ elektron, dan $\mathrm{f} \leq 14$ elektron. Menurut Bohr, jumlah maksimum elektron dalam setiap kulit atom atau lintasan elektron dirumuskan sebagai $2 n^{2}$ dimana $n$ adalah bilangan kuantum utama. Bilangan kuantum utama adalah 
bilangan penunjuk letak elektron, sebab bilangan kuantum utama menentukan letak elektron pada kulit atom dan menentukan besarnya jari-jari atom. Nilai bilangan kuantum utama (n) adalah 1, 2, 3, yang setara dengan kulit K, kulit L, dan seterusnya. Banyaknya subkulit yang dimiliki setiap kulit atom sama dengan nilai $\mathrm{n}$ dari kulit yang bersangkutan. Secara skematis lintasan elektron dapat diilustrasikan pada Cambar 1-1, sedangkan efek Stark dijelaskan dengan Cambar 1-2.

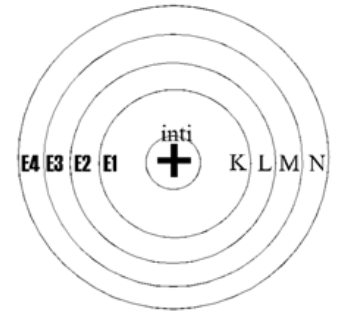

Gambar 1-1: Lintasan Atom

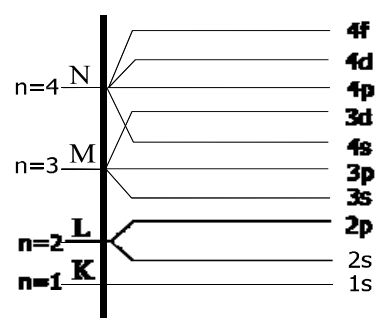

Gambar 1-2: Diagram Energi Kulit Atom

Susunan elektron untuk berbagai unsur seperti disajikan pada Tabel 1-1 berikut ini.

\section{Tabel 1-1: Susunan Elektron}

\begin{tabular}{|c|c|c|c|c|c|c|c|c|c|c|c|c|c|c|c|c|c|c|c|}
\hline \multirow{2}{*}{ No. } & \multirow{2}{*}{ Unsur } & \multirow{2}{*}{$\begin{array}{l}1 \\
\mathrm{~s} \\
\end{array}$} & \multicolumn{2}{|c|}{2} & \multicolumn{3}{|c|}{3} & \multicolumn{4}{|c|}{4} & \multicolumn{4}{|c|}{5} & \multicolumn{3}{|c|}{6} & \multirow{2}{*}{$\frac{7}{s}$} \\
\hline & & & $s$ & $p$ & $s$ & $p$ & $d$ & $\mathrm{~s}$ & 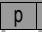 & $d$ & $f$ & $\mathrm{~s}$ & \begin{tabular}{|l|l|} 
\\
\end{tabular} & $d$ & $f$ & $s$ & $p$ & $d$ & \\
\hline 1 & $\mathrm{H}$ & 1 & & & & & & & & & & & & & & 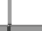 & 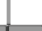 & 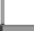 & \\
\hline & & & & & & & & & & & & & & & & & & & \\
\hline 3 & Li & 2 & 1 & & & & & & & & & & & & & & & & \\
\hline 4 & $\mathrm{Be}$ & 2 & 2 & & & & & & & & & & & & & & & & \\
\hline 5 & B & 2 & 2 & 1 & & & & & & & & & & & & & & & \\
\hline 6 & $C$ & 2 & 2 & 2 & & & & & & & & & & & & & & & \\
\hline 7 & $\mathrm{~N}$ & 2 & 2 & 3 & & & & & & & & & & & & & & & \\
\hline 8 & 0 & 2 & 2 & 4 & & & & & & & & . & & & & & & & \\
\hline 9 & $F$ & 2 & 2 & 5 & & & & & & & & & & & & & & & \\
\hline & & & & & & & & & & & & & & & & & & & \\
\hline 11 & $\mathrm{Na}$ & 2 & 2 & 6 & 1 & & & & & & & & & & & & & & \\
\hline 12 & $\mathrm{Mg}$ & 2 & 2 & 6 & 2 & & & & & & & & & & & & & & \\
\hline 13 & $\mathrm{Al}$ & 2 & 2 & 6 & 2 & 1 & & & & & & & & & & & & & \\
\hline 14 & $\mathrm{Si}$ & 2 & 2 & 6 & 2 & 2 & & & & & & & & & & & & & \\
\hline 15 & $P$ & 2 & 2 & 6 & 2 & 3 & & & & & & & & & & & & & \\
\hline 16 & $S$ & 2 & 2 & 6 & 2 & 4 & & & & & & & & & & & - & & \\
\hline 17 & $\mathrm{Cl}$ & 2 & 2 & 6 & 2 & 5 & & & & & & & & & & & & & 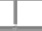 \\
\hline
\end{tabular}




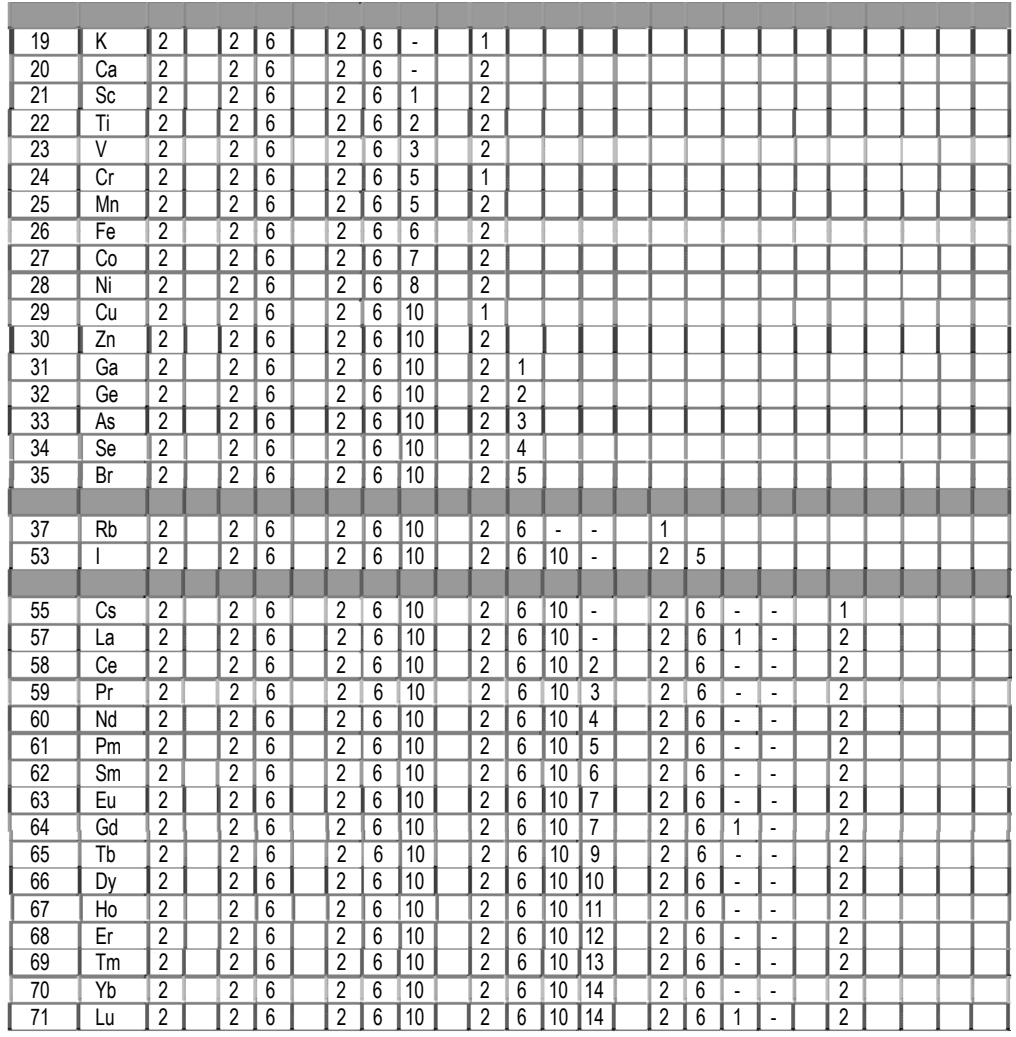

\section{Tabel 1-1: Susunan Elektron (lanjutan)}

\begin{tabular}{|c|c|c|c|c|c|c|c|c|c|c|c|c|c|c|c|c|c|c|c|}
\hline No & Unsur & 1 & & & & 3 & & & & & & & & & & & 6 & & 7 \\
\hline No. & Unsur & s & $s$ & $p$ & $\mathrm{~s}$ & $p$ & d & s & p & d & $f$ & s & p & d & f & s & $p$ & d & $s$ \\
\hline 85 & At & 2 & 2 & 6 & 2 & 6 & 10 & 2 & 6 & 10 & 14 & 2 & 6 & 10 & - & 2 & 5 & & \\
\hline 87 & $\mathrm{Fr}$ & 2 & 2 & 6 & 2 & 6 & 10 & 2 & 6 & 10 & 14 & 2 & 6 & 10 & - & 2 & 6 & - & 1 \\
\hline
\end{tabular}

\subsection{IKATAN KIMIA}

Pada dasarnya ikatan kimia merupakan tarik menarik antara dua atom atau lebih dalam suatu molekul. Ikatan antar atom melibatkan elektron-elektron pada kulit terluarnya. Pada 
hakekatnya setelah berikatan makan susunan elektron masingmasing atom akan mencapai kestabilan. Menurut teori oktet dari Lewis, kestabilan ini akan dicapai apabila mempunyai susunan elektron seperti gas mulia, yaitu apabila pada kulit terluarnya terdapat 8 elektron, kecuali atom $\mathrm{He}$.

$$
\text { Contoh: } \begin{aligned}
{ }_{2} \mathrm{He} & : 2 \\
{ }_{10} \mathrm{Ne} & : 2,8 \\
{ }_{18}^{18} \mathrm{Ar} & : 2,8,8 \\
{ }_{36} \mathrm{Kr} & : 2,8,18,8 \\
{ }_{54} \mathrm{Xe} & : 2,8,18,18,8
\end{aligned}
$$

Susunan elektron seperti gas mulia ini akan diperoleh melalui dua cara, yaitu cara serah terima elektron dan persekutuan elektron. Sebagai gambaran atom-atom yang menyerahkan atau menerima elektron seperti pada Tabel 2-2 berikut ini.

\section{Tabel 1-2: Kemampuan Menyerahkan atau Menerima Elektron}

\begin{tabular}{|c|c|c|c|c|c|}
\hline \multicolumn{6}{|c|}{ Golongan Atom Menurut Sistem Berkala Unsur } \\
\hline VIA & VIIA & VIIIA & IA & IIA & IIIA \\
\hline & & $\mathrm{He}$ & & & \\
\hline $\mathrm{O}$ & $\mathrm{F}$ & $\mathrm{Ne}$ & $\mathrm{Li}$ & $\mathrm{Be}$ & $\mathrm{B}$ \\
\hline $\mathrm{S}$ & $\mathrm{Cl}$ & $\mathrm{Ar}$ & $\mathrm{Na}$ & $\mathrm{Mg}$ & $\mathrm{Al}$ \\
\hline $\mathrm{Sc}$ & $\mathrm{Br}$ & $\mathrm{Kr}$ & $\mathrm{K}$ & $\mathrm{Ca}$ & \\
\hline $\mathrm{Te}$ & $\mathrm{I}$ & $\mathrm{Xe}$ & $\mathrm{Rb}$ & $\mathrm{Sr}$ & \\
\hline \multicolumn{7}{|c|}{ menerima elektron } & $\mathrm{Rn}$ & $\mathrm{Ba}$ & \\
\hline & & $\cdot$ & \multicolumn{3}{l|}{ memberikan elektron } \\
\hline
\end{tabular}

a. Ikatanlonik/Elektrovalen

Dasar ikatan inonik adalah serah terima elektron valensi. Ikatan ionik adalah ikatan kimia yang terbentuk antara ion-ion 
yang mempunyai muatan berlawanan. Jadi ikatan ion tersusun atas ion positif (logam) dan ion negatif (bukan logam). Ikatan ion umumnya terjadi antara unsur-unsur golongan IA dengan golongan VIIA atau antara unsur-unsur golongan IIA dengan golongan VIIA. Terjadinyan ikatan ionik disebabkan oleh adanya gaya elektrostatika antara ion positif (kation) dan ion negatif (anion).

Kation akan terbentuk apabila suatu atom telah melepaskan satu elektron valensinya atau lebih sehingga atom tersebut bermuatan positif karena kekurangan elektron, pada umumnya berupa unsur logam, yaitu unsur golongan IA dan golongan IIA.

Anion akan terbentuk apabila suatu atom telah menerima satu elektron atau lebih pada kulit terluarnya, sehingga atom tersebut bermuatan negatif karena kelebihan elektron, pada umumnya berupa unsur bukan logam, yaitu unsur-unsur golongan VIA sampai golongan VIIA.

Contoh: Pengikatan antara $\mathrm{Na}$ dan $\mathrm{Cl}$

$$
\begin{aligned}
& { }_{11} \mathrm{Na}=2,8,1 \\
& \text { (golongan IA) } \\
& \longrightarrow \begin{array}{l}
\mathrm{Na}^{+}=2,8+\mathrm{e}^{-} \\
(\text {sama dengan } \mathrm{Ne} \text { ) }
\end{array} \\
& + \\
& \mathrm{NaCl} \\
& { }_{17} \mathrm{Cl}=2,8,7+\mathrm{e}^{-} \\
& \text {(golongan VIIA) } \\
& \begin{array}{l}
\longrightarrow \mathrm{Cl}^{-}=2,8,8 \\
(\text { sama dengan Ar) }
\end{array}
\end{aligned}
$$

$\mathrm{Na}$ berusaha untuk mempunyai susunan elektron sama dengan $\mathrm{Ne}$, maka $\mathrm{Na}$ akan melepaskan satu elektronnya yang berada pada subkulit $3 s^{1}$ agar kulit kedua jumlah elektronnya menjadi delapan. Akibatnya $\mathrm{Na}$ bermuatan positif karena kekurangan elektron. Na cenderung melepaskan elektron karena 
termasuk dalam golongan IA. Sedangkan $\mathrm{Cl}$ berusaha untuk mempunyai susunan elektron sama dengan Ar, maka jumlah elektron pada subkulit $3 p^{5}$ perlu ditambah satu elektron agar menjadi $3 p^{6}$ sehingga kulit ketiga jumlah elektronnya menjadi delapan. Akibatnya $\mathrm{Cl}$ bermuatan negatif karena kelebihan elektron. $\mathrm{Cl}$ cenderung menerima elektron karena termasuk unsur dalam golongan VIIA.

Sifat persenyawaan elektrovalen / ionik adalah sebagai berikut.

1. Ikatannya tidak kuat, karena hanya merupakan ikatan akibat gaya tarik menarik antara dua muatan listrik yang berlainan.

2. Persenyawaan ionik berbentuk kristal, apabila dilarutkan dalam air akan mengalami disosiasi, yaitu ion-ion akan terpisah antara satu dengan lainnya.

3. Persenyawaan ionik umumnya berbentuk padat yang sukar menguap karena pasangan ion dalam ikatan ionik mempunyai dipolmomen listrik yang besar sehingga melekat kuat pada pasangan ionnya.

4. Persenyawaan ionik larut dalam pelarut polar, misalnya air dan larutan yang dihasilkan dapat menghantarkan arus listrik.

Suatu persenyawaan mempunyai bentuk ikatan ionik/ elektrovalen apabila sebuah elektron atau lebih di antara salah satu atom penyusunnya dapat meninggalkan lintasannya dan masuk ke dalam lintasan atom lain pasangannya. Kemampuan elektron untuk melepaskan diri meninggalkan lintasannya dipengaruhi oleh: 
a. Kekuatan medan listrik yang ditimbulkan oleh intinya masing-masing. Hal ini tergantung kepada:

1). Jari-jari ion

semakin besar jari-jarinya, maka semakin kecil kekuatan medan listrik yang ditimbulkan dan sebaliknya.

2). Konfigurasi elektron

apabila konfigurasi elektron menyelubungi (screening) inti terhadap sekelilingnya, maka kekuatan medan listriknya kecil. Misalnya gas inert mempunyai konfigurasi elektron menyelubungi intinya, maka kekuatan medan listriknya kecil.

b. Stabilitas konfigurasi elektron kedua atom penyusunnya setelah pemindahan elektron. Apabila kekuatan medan listrik yang ditimbulkan oleh intinya terhadap sekelilingnya kecil akan terbentuk kation (ion positif), karena ion yang terlepas tidak akan tertarik kembali. Dalam hal ini, atom tersebut bertindak sebagai donor elektron. Apabila medan listrik positif ada di sekeliling intinya besar akan terbentuk anion (ion negatif) karena elektron yang telah masuk ke dalam orbitnya, yaitu pada lintasan atau kulit terluarnya tidak dapat terlepas. Dalam hal ini atom tersebut bertindak sebagai akseptor elektron.

b. Ikatan Kovalen/Homopolar

Dasar ikatan kovalen adalah persekutuan elektron atau penggunaan elektron secara bersama-sama. Hal ini terjadi pada 
atom-atom yang kemampuan terionnya kecil, maka pengikatan akan terjadi dengan cara pemakaian bersama-sama sepasang elektron atau lebih oleh dua atom yang berikatan.

Masing-masing atom yang berikatan akan menyumbangkan satu atau lebih elektronnya yang berada pada kulit terluarnya untuk dipakai secara bersama-sama dengan atom pasangannya. Ikatan kovalen banyak terjadi antara atom-atom unsur bukan logam. Pemakaian elektron secara bersama-sama ini tujuannya agar masing-masing atom penyusun persenyawaan mempunyai susunan elektron sama dengan gas mulia atau jumlah elektron pada kulit terluarnya menjadi delapan (oktet).

Pengikatan kovalen dapat terjadi melalui dua cara, yaitu: persekutuan dua pihak dan persekutuan sepihak. Ikatan persekutuan dua pihak dapat berbentuk ikatan tunggal, ikatan rangkap dua, dan ikatan rangkap tiga.

Contoh:

a. Ikatan persekutuan dua pihak

1). Ikatan tunggal, misalnya $\mathrm{F}_{2}, \mathrm{Cl}_{2}, \mathrm{H}_{2}$. ${ }_{9} \mathrm{~F}=2,7 \quad$ (elektron valensinya $=7$ )

$$
\ddot{\mathrm{F}}+\ddot{\mathrm{F}}: \longrightarrow: \ddot{\mathrm{F}}: \ddot{\mathrm{F}}:
$$

2). Ikatan rangkap dua, misalnya $\mathrm{O}_{2}$

${ }_{8} \mathrm{O}=2,6$ (elektron valensinya $=6$ )

$: 0:+: 0: \longrightarrow: 0:: 0:$

3). Ikatan rangkap tiga, misalnya $\mathrm{N}_{2}$

${ }_{7} \mathrm{~N}=2,5 \quad$ (elektron valensinya $=5$ )

$: \mathrm{N}:+\mathrm{N}: \longrightarrow: \mathrm{N}: \mathrm{N}:$ 
b. Ikatan persekutuan sepihak

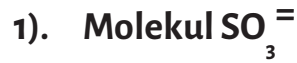

$$
\begin{aligned}
{ }_{16} \mathrm{~S} & =2,8,6 \quad(\text { elektron valensinya }=6) \\
\mathrm{O} & =2,6 \quad(\text { elektron valensinya }=6) \\
& : \ddot{0}: \mathrm{s}:: \ddot{0} \\
: & : 0:
\end{aligned}
$$

2). Molekul $\mathrm{NH}_{4}^{+}$

$$
\left[\begin{array}{c}
\mathbf{H} \\
\mathbf{H}: \stackrel{\mathrm{N}}{:} \mathbf{H} \\
\ddot{\mathrm{H}}
\end{array}\right]^{+}
$$

3). Molekul $\left[\mathrm{Cu}\left(\mathrm{NH}_{3}\right)_{4}\right]^{2+}$

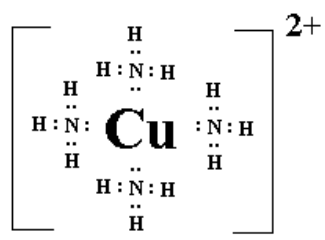

\section{VALENSI}

Valensi suatu unsur adalah banyaknya atom $\mathrm{H}$ yang dapat diikat oleh satu atom suatu unsur untuk membentuk satu molekul senyawa.

atau :

Valensi suatu unsur adalah banyaknya $1 / 2$ atom $O$ yang dapat diikat oleh satu atom suatu unsur untuk membentuk satu molekul senyawa. 
Contoh:

1). Dalam satu molekul HF, maka 1 atom $\mathrm{F}$ mengikat 1 atom $H$, sehingga valensi $F=1$.

2). Dalam satu molekul $\mathrm{Fe}_{2} \mathrm{O}_{3}$, maka 1 atom Fe mengikat $3 x$ $1 / 2$ atom $\mathrm{O}$, sehingga valensi $\mathrm{Fe}=3$.

Cara menghitung:

$$
\begin{aligned}
\mathrm{Fe}_{2} \mathrm{O}_{3} \operatorname{artinya} 2 \times \mathrm{Fe} & =3 \times \mathrm{O} \\
\mathrm{Fe} & =3 / 2 \times \mathrm{O} \\
\mathrm{Fe} & =3 / 2 \times(2 \times 1 / 2 \mathrm{O}) \\
\mathrm{Fe} & =3 / 2 \times 2(1 / 2 \mathrm{O}) \\
\mathrm{Fe} & =3 \times 1 / 2 \mathrm{O}
\end{aligned}
$$

Jadi valensi $\mathrm{Fe}=3$

3). Dalam satu molekul $\mathrm{SiO}_{2}$, maka 1 atom Si mengikat $4 \times 1 / 2$ atom $\mathrm{O}$, sehingga valensi $\mathrm{Si}=4$

Cara menghitung:

$$
\begin{aligned}
& \mathrm{SiO}_{2} \operatorname{artinya} 1 \times \mathrm{Si}=2 \times \mathrm{O} \\
& \mathrm{Si}=2 \times \mathrm{O} \\
& \mathrm{Si}=2 \times(2 \times 1 / 2 \mathrm{O}) \\
& \mathrm{Si}=4 \times 1 / 2 \mathrm{O}
\end{aligned}
$$

Jadi valensi $\mathrm{Si}=4$

Beberapa valensi unsur-unsur penting seperti disajikan pada Tabel 2-3. Cara penulisan rumus molekul suatu senyawa yang disusun oleh dua atom misalnya atom "A" dengan valensi "a" dan atom "B" dengan valensi " $b$ ", maka rumus molekulnya adalah $A_{b} B_{a}$. Apabila " $a=$ b", maka penulisan indeks a dan b dalam rumus molekul tersebut ditiadakan, sehingga rumus molekulnya $A B$ saja. 
Tabel 2-3: Daftar Valensi Beberapa Unsur

\begin{tabular}{|c|c|l|c|c|l|}
\hline No. Atom & Unsur & Valensi & No. Atom & Unsur & \multicolumn{1}{|c|}{ Valensi } \\
\hline 47 & $\mathrm{Ag}$ & 1 & 80 & $\mathrm{Hg}$ & 1,2 \\
\hline 13 & $\mathrm{Al}$ & 3 & 53 & $\mathrm{I}$ & $1,3,5,7$ \\
\hline 79 & $\mathrm{Au}$ & 1,3 & 19 & $\mathrm{~K}$ & 1 \\
\hline 33 & $\mathrm{As}$ & 3,5 & 12 & $\mathrm{Mg}$ & 2 \\
\hline 85 & $\mathrm{Al}$ & 1,3 & 25 & $\mathrm{Mn}$ & $2,3,4,6,7$ \\
\hline 5 & $\mathrm{~B}$ & 3 & 7 & $\mathrm{~N}$ & $2,3,4,5$ \\
\hline 56 & $\mathrm{Ba}$ & 2 & 11 & $\mathrm{Na}$ & 1 \\
\hline 35 & $\mathrm{Br}$ & 1,5 & 28 & $\mathrm{Ni}$ & 2,3 \\
\hline 6 & $\mathrm{C}$ & 4 & 8 & $\mathrm{O}$ & 2 \\
\hline 20 & $\mathrm{Ca}$ & 2 & 15 & $\mathrm{P}$ & $3,4,5$ \\
\hline 27 & $\mathrm{Co}$ & 1,2 & 82 & $\mathrm{~Pb}$ & 2,4 \\
\hline 17 & $\mathrm{Cl}$ & $1,3,5,7$ & 16 & $\mathrm{~S}$ & $2,4,6$ \\
\hline 24 & $\mathrm{Cr}$ & $2,3,6$ & 51 & $\mathrm{Sb}$ & 3,5 \\
\hline
\end{tabular}

\section{c. Ikatan Kompleks (Ikatan Koordinasi)}

Ikatan kompleks pada suatu persenyawaan terbentuk karena terjadi ikatan antara ion dengan ion lain atau antara ion dengan molekul netral. Menurut Werner, atom logam akan diikat langsung oleh atom-atom atau kelompokatom maupun molekul. Dasar terbentuknya senyawa kompleks adalah terjadinya ikatan antara ligand dan ion logam sebagai pusatnya. Ligand adalah gugus koordinasi atau ion yang terikat pada ion pusat berupa logam pada senyawa kompleks. Gugus koordinasi berupa ion atau molekul yang dapat memberi pasangan elektron bebas atau sebagai donor elektron. Ion pusat adalah ion penerima pasangan elektron bebas atau sebagai akseptor elektron. 
Banyaknya gugus koordinasi yang terikat pada ion pusat suatu senyawa kompleks disebut bilangan koordinasi atau valensi koordinasi.

Contoh: $\mathrm{CoCl}_{3}+6 \mathrm{NH}_{3} \longrightarrow \mathrm{Co}\left(\mathrm{NH}_{3}\right)_{6}^{3+}+3 \mathrm{Cl}$

atau

$\left\{\mathrm{Co}\left(\mathrm{NH}_{3}\right)_{6} \mathrm{Cl}_{3}\right.$

- Ketiga atom $\mathrm{Cl}$ tetap bebas, hal ini dapat dibuktikan misalnya ditambahkan $\mathrm{AgNO}_{3}$ akan terbentukendapan $\mathrm{AgCl}$.

- Logam ion pusatnya adalah Co.

- Cugus koordinasinya (ligand) adalah $\mathrm{NH}_{3}$.

- Bilangan koordinasi (valensi koordinasi) $=6$.

- Elektrovalensi $\mathrm{CO}_{\mathrm{O}} 3^{+}$, sedangkan valensi $\mathrm{Co}=1$

- Valensiion kompleks $=3+$

- Elektrovalensi $\mathrm{NH}_{3}=\mathrm{O}$ (netral)

Pada contoh di atas merupakan bentuk pengikatan kompleks antara logam (Co) dengan molekul $\mathrm{NH}_{3}$ ) membentuk ion kompleks $\left\{\mathrm{Co}\left(\mathrm{NH}_{3}\right)\right\}^{3+}$. Senyawa atau ion kompleks dapat berupa ion kompleks positif dan ion kompleks negatif. Ion kompleks positif misalnya $\left\{\mathrm{Ag}\left(\mathrm{NH}_{3}\right)^{2}\right\}^{+}$yang disusun oleh ion pusat $\mathrm{Ag}^{+}$dan gugus koordinasi (ligand) $\mathrm{NH}^{3}$. Ion kompleks negatif misalnya $\left\{\mathrm{CoF}_{6}\right\}^{3-}$ yang disusun oleh ion pusat $\mathrm{Co}^{3+}$ dan gugus koordinasi (ligand) F .

\section{d. Ikatan Hidrogen}

Dasar pengikatan hidrogen adalah adanya polaritas atau pengutuban atom-atom pembentuk molekul. Misalnya pada air 
yang bersifat bipolar atau dwikutub sehingga memungkinkan terjadinya ikatan hidrogen antar molekul air. Sebenarnya ikatan hidrogen tidak terbatas pada molekul air dengan molekul air atau molekul air dengan molekul polar lainnya, tetapi juga antara atom hidrogen dalam molekul bukan air dengan molekul polar lainnya.

Contoh:

1). Ikatan hidrogen antara air dengan alkohol

$$
\begin{array}{cc}
\mathrm{CH}_{3}-\mathrm{CH}_{2}-\mathbf{0}-\mathbf{H} \cdots \cdots & \mathbf{0}-\mathbf{H} \\
& \mathbf{H} \\
\mathbf{H}-\mathbf{R}-\mathbf{0} \cdots \cdots \cdot \mathbf{H}-\mathbf{0} & \\
\mathbf{H} & \\
\mathbf{H} &
\end{array}
$$

2). I katan hidrogen antara dua molekul etanol<smiles>CCOC=O</smiles>

3). Ikatan hidrogen antara asam karboksilat dengan air<smiles>[R]C(=O)O[CH]O</smiles>

Ikatan hidrogen sangat lemah dibandingkan dengan ikatan kovalen, tetapi ikatan hidrogen memegang peranan penting dalam biokimia sebab mereka dapat dibentuk dalam jumlah besar. Ikatan hidrogen berperanan pada banyak molekul bipolar misalnya air, alkohol, DNA, dan protein. 


\subsection{REAKSI KIMIA}

Reaksi kimia didasarkan pada hukum kekekalan massa, yaitu massa tidak dapat diciptakan atau dihancurkan. Oleh karena itu, dalam reaksi kimia harus berpedoman bahwa jumlah massa produk harus sama dengan jumlah massa reaktan. Hal ini penting misalnya untuk mengetahui reaktan mana yang harus tersedia berlebihan agar diperoleh produk sesuai dengan yang diinginkan.

Contoh: Reaksi antara $\mathrm{C}+\mathrm{O}_{2}$

$$
\begin{array}{ll}
\mathrm{C}_{\text {(cukup) }}+\mathrm{O}_{2} \text { (berlebihan) } & \mathrm{CO}_{2} \\
\mathrm{C}_{\text {(cukup) }}+\mathrm{O}_{2} \text { (terbatas) } & \longrightarrow \mathrm{CO}_{\text {(racur) }}
\end{array}
$$

Kelebihan jumlah reaktan yang tersedia tidak bereaksi dan jumlah produk tergantung pada tersedianya reaktan dalam jumlah relatif kecil.

Reaksi kimia ditulis dengan lambang-lambang dalam persamaan kimia, untuk menyatakan reaktan pereaksi dan produk yang terbentuk. Berdasarkan hukum kekekalan massa, maka berat sebelum dan sesudah reaksi harus sama, sehingga jumlah atom dari masing-masing unsur harus tetap. Oleh karena itu kadang-kadang diperlukan angka koefisien untuk menyatakan jumlah atom-atom tersebut.

Suatu reaksi kimia, khususnya untuk bahan organik ditandai adanya interaksi antar molekul. Dalam peristiwa ini akan terjadi pemutusan ikatan dalam molekul reaktan dan bersamaan itu pula terjadi pembentukan ikatan baru, sehingga terbentuk molekul baru. Adanya interaksi antar molekul akan terjadi gaya 
tarik menarik muatan, yaitu muatan negatif dan muatan positif yang terdapat dalam molekul yang berinteraksi. Setelah berinteraksi, kemudian melalui gerakan pasangan elektron akan terjadi perubahan-perubahan. Perubahan-perubahan ini disebut terjadi reaksi. Reaksi dapat digolongkan menjadi tiga, yaitu adisi, substitusi, dan eliminasi.

\section{a. Adisi}

Reaksi adisi terjadi pada senyawa tidak jenuh. Banyaknya atom atau gugus dari pereaksi yang teradisi tidak melebihi bilangan koordinasi maksimum dari atom molekul tak jenuh itu sendiri.

Ikatan rangkap yang sering mengalami reaksi adisi adalah ikatan rangkap dua karbon-karbon (-C=C-) dan ikatan rangkap tiga karbon-karbon (-C $=\mathrm{C}-$ ), serta ikatan rangkap dua karbonoksigen $(-\mathrm{C}=\mathrm{O})$. Contoh pereaksi yang mengadisi pada ikatan tidak jenuh, misalnya brom $\left(\mathrm{Br}_{2}\right)$ dan hidrogen $\left(\mathrm{H}_{2}\right)$. Untuk pereaksi hidrogen memerlukan katalisator.

Contoh:

$$
\begin{aligned}
& -\mathrm{CH}=\mathrm{CH}_{2}+\mathrm{Br}_{2} \longrightarrow-\mathrm{CHBr}_{2} \mathrm{CH}_{2} \mathrm{Br} \\
& -\mathrm{C}=\mathrm{CH}+\mathrm{Br}_{2} \longrightarrow-\mathrm{CBr}=\mathrm{CHBr} \longrightarrow-\mathrm{CBr}_{2}-\mathrm{CHBr}_{2} \\
& -\mathrm{CH}=\mathrm{CH}_{2}+\mathrm{H}_{2} \longrightarrow-\mathrm{CH}_{2}-\mathrm{CH}_{3} \\
& \mathrm{CH}_{2}=\mathrm{CH}_{2}+\mathrm{HCl} \longrightarrow \mathrm{HCH}_{2}-\mathrm{CH}_{2} \mathrm{Cl}
\end{aligned}
$$




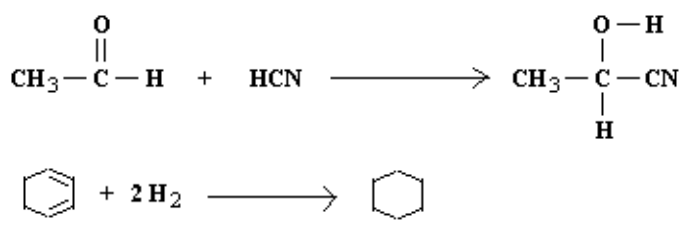

\section{b. Substitusi}

Reaksi substitusi terjadi apabila sebuah atom atau gugus yang berasal dari pereaksi menggantikan sebuah atom atau gugus dari molekul yang bereaksi. Reaksi substitusi dapat terjadi pada atom karbon jenuh atau tidak jenuh.

Contoh:

$$
\begin{aligned}
& \mathrm{CH}_{3}-\mathrm{CH}_{2}-\mathrm{OH}+\mathrm{HBr} \longrightarrow \mathrm{CH}_{3}-\mathrm{CH}_{2}-\mathrm{Br}+\mathrm{H}_{2} \mathrm{O} \\
& 2 \mathrm{CH}_{3}-\mathrm{CH}_{2}-\mathrm{CH}_{3}+2 \mathrm{Cl}_{2} \longrightarrow \mathrm{CH}_{3}-\mathrm{CH}_{2}-\mathrm{CH}_{2}-\mathrm{Cl}+\mathrm{CH}_{3}-
\end{aligned}
$$

$\mathrm{CHCl}-\mathrm{CH}_{3}+2 \mathrm{HCl}$

\section{c. Eliminasi}

Reaksi eliminasi adalah kebalikan dari reaksi adisi. Dalam reaksi ini bagian yang tereliminasi atau terpisahkan adalah atom bukan karbon.

Contoh:

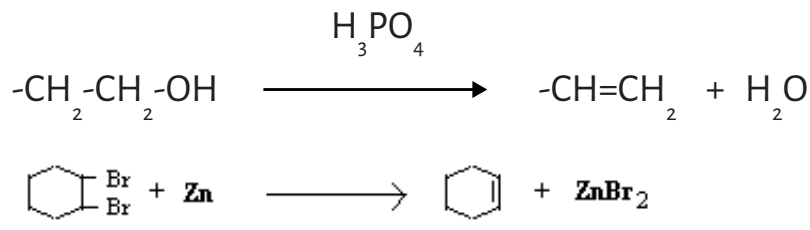




\subsection{OKSIDASI DAN REDUKSI}

Secara klasik, oksidasi diartikan sebagai reaksi antara suatu zat dengan oksigen. Sedangkan reduksi diartikan sebagai reaksi antara suatu zat dengan hidrogen. Pada perkembangannya sesuai dengan teori elektron, maka yang dimaksud oksidasi adalah pelepasan elektron atau kenaikan bilangan oksidasi.

Sedangkan reduksi adalah pengikatan elektron atau penurunan bilangan oksidasi. Pengertian bilangan oksidasi adalah muatan listrik (positif atau negatif) yang seakan-akan dimiliki oleh unsur dalam senyawa atau ion. Aturan penentuan bilangan oksidasi adalah sebagai berikut.

1. Unsur bebas mempunyai bilangan oksidasi $=0$

Unsur bebas adalah unsur yang tidak berikatan dengan unsur lain.

2. Bilangan oksidasi unsur $\mathrm{O}$ (dalam senyawa) $=-2$, kecuali:
a. dalam peroksida $=-1$
b. dalam superoksida $=-1 / 2$
c. dalam $\mathrm{OF}_{2}=+2$

3. Bilangan oksidasi unsur $\mathrm{H}$ (dalam senyawa) $=+1$, kecuali dalam hidrida $=-1$

4. Bilangan oksidasi ion sederhana = banyaknya muatan ionnya, ion sederhana adalah ion yang hanya terdiri dari satu atom.

5. Bilangan oksidasi setiap atom dalam ion kompleks = banyaknya muatan ionnya.

6. Jumlah bilangan oksidasi atom-atom dalam molekul netral $=0$ hal ini sesuai dengan hukum kekekalan massa. 
7. Bilangan oksidasi unsur golongan $I A$ (dalam senyawa) $=+1$

8. Bilangan oksidasi unsur golongan IIA (dalam senyawa) $=+2$

9. Unsur golongan lain sesuai dengan valensinya dan diberi tanda +

Peristiwa perubahan kimia, dimana terjadi perpindahan elektron dari satu reaktan ke reaktan lainnya dalam waktu bersamaan disebut peristiwa oksidasi-reduksi yang juga dikenal sebagai reaksi redox. Ditinjau dari perubahan bilangan oksidasinya, maka peristiwa ini juga terjadi penambahan dan pengurangan bilangan oksidasi secara bersama-sama.

\subsection{GUGUS FUNGSIONAL}

Gugus fungsional adalah susunan spesifik dari elemenelemen yang pada umumnya berupa (C, H, O, N, S, P) yang sifat kimia dan fisikanya telah dikenal dengan baik. Berikut ini akan dibahas tentang gugus fungsional pada alkohol, aldehid dan keton, asam karboksilat, serta amina.

\section{a. Alkohol}

Senyawa alkohol mempunyai dua sifat sekaligus, yaitu bersifat polar dan nonpolar. Alkohol bersifat polar karena mempunyai gugus hidroksil $(-\mathrm{OH})$, dan bila ditinjau dari gugus alkilnya, maka alkohol bersifat nonpolar. Beberapa senyawa alkohol yang penting dalam bahan pangan antara lain: gula, lipida tertentu, dan asam amino. Dalam peristiwa biokimia, alkohol dapat mengalami beberapa reaksi kimia, antara lain oksidasi, pengesteran, dan pengeteran. 


\section{Oksidasi}

Oksidasi terjadi bila zat pengoksidasi kuat. Alkohol primer akan teroksidasi menjadi aldehid dan asam. Alkohol sekunder akan teroksidasi menjadi keton. Alkohol tersier tidak dapat teroksidasi.

[0]

$\mathrm{R}-\mathrm{CH}_{2} \mathrm{OH} \longrightarrow \begin{aligned} & \mathrm{R}-\mathrm{CHO}+ \\ & \text { alkoholprimer }\end{aligned}$
aldehid $-\mathrm{COOH}$

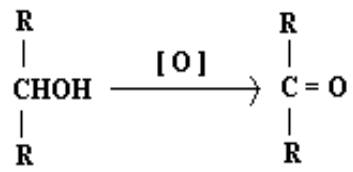

alkoholsekunder keton

\section{Pengesteran}

Ester terbentuk apabila air dikeluarkan dari rekasi antara alkohol primer / alkohol sekunder / alkohol tersier dengan asam organik/ asam anorganik.

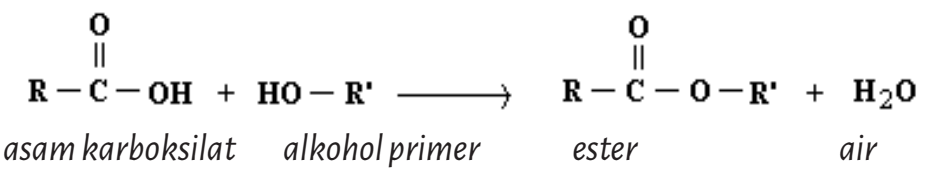

\section{Pengetaran}

Eter merupakan derivat alkohol, dimana hidrogen dari gugus -OH diganti oleh gugus alkil (-R). Ikatan eter jarang ditemukan dalam jaringan hidup.

$$
\mathrm{R}-\mathrm{CH}_{2}-\mathrm{O}-\mathrm{R}_{2}
$$




\section{b. Aldehid dan Keton}

Gugus karbonil ( $>\mathrm{C}>\mathrm{O}$ ) dalam aldehid dan keton mempunyai sifat reduksi yang kuat. Aldehid mempunyai satu gugus alkil $(\mathrm{RCOH})$ dan keton mempunyai dua gugus alkil (RCOR') yang terikat pada karbon bergugus karbonil. Contohnya gula merupakan alkohol polihidrat, baik dalam bentuk aldehid maupun keton. Reaksi aldehid dan keton yang penting antara lain oksidasi, reduksi, pembentukan hemiasetal atau asetal, dan kondensasi.

\section{Oksidasi}

Aldehid teroksidasi menjadi asam karboksilat yang bersangkutan. Keton tidak dapat teroksidasi atau melepaskan hidrogennya tanpa merusak ikatan C-C nya, karena keton mempunyai struktur seperti alkohol tersier.

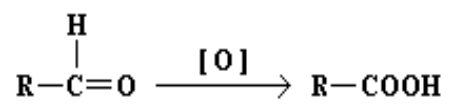

aldehid asam karboksilat

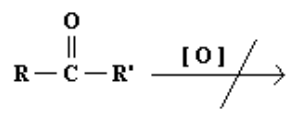

keton

\section{Reduksi}

Aldehid tereduksi menghasilkan alkohol primer yang sesuai. Keton tereduksi menghasilkan alkohol sekunderyang sesuai.

$$
\begin{array}{ll}
\mathrm{R}-\mathrm{CH}=0 \stackrel{2 \mathrm{H}}{\longrightarrow} & \mathrm{R}-\mathrm{CH}_{2}-\mathrm{OH} \\
\text { aldehid } & \text { alkohol primer }
\end{array}
$$




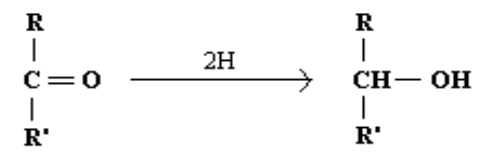

keton alkohol sekunder

3. Pembentukan Hemiasetal atau Asetal

Dalam kondisi asam, aldehid dapat bergabung dengan satu atau dua hidroksi $(-\mathrm{OH})$ dari alkohol dan masing-masing membentuk hemiasetal atau asetal.

$$
\mathrm{R}-\mathrm{CH}=\mathrm{O}+\mathrm{R}^{\prime}-\mathrm{OH} \longrightarrow \begin{aligned}
& \mathrm{R}-\mathrm{CH}-\mathrm{OH} \\
& \mathrm{l}-\mathrm{R}^{\prime}
\end{aligned}
$$

aldehid alkohol hemiasetal

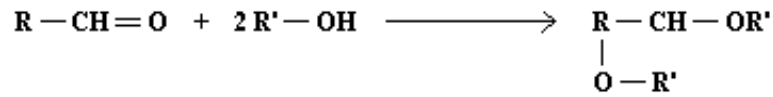

$$
\begin{aligned}
& \text { aldehid } 2 \text { alkohol asetal }
\end{aligned}
$$

\section{Kondensasi}

Pada kondisi alkali, aldehid dan beberapa keton mengalami kondensasi antara gugus karbonil dan atom-atom karbon alfa membentuk aldol.

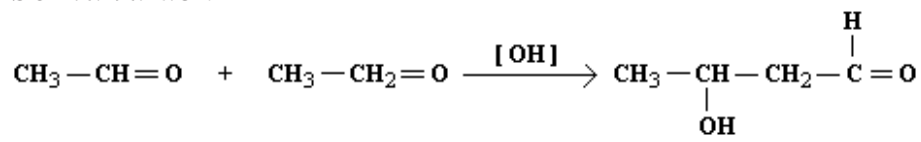

$$
\begin{aligned}
& \text { aldehid aldehid aldol }
\end{aligned}
$$

\section{c. Asam Karboksilat}

Asam karboksilat mempunyai gugus karbonil $(>\mathrm{C}=\mathrm{O}$ ) dan gugus hidroksil $(-\mathrm{OH})$ pada atom karbon yang sama. 
Beberapa reaksi yang penting antara lain reduksi, pengesteran (tioester), pembentukan anhidrida asam, pembentukan garam, pembentukan amida.

1. Reduksi

Reduksi asam karboksilat (askorbat) menghasilkan alkohol primer yang sesuai.

$$
\begin{array}{ll}
\mathbf{R}-\mathbf{C O O H} \underset{[4 \mathrm{H}]}{\longrightarrow} & \mathbf{R}-\mathrm{CH}_{2}-\mathrm{OH}+\mathbf{H}_{2} \mathbf{O} \\
\text { asam karboksilat } & \text { alkohol primer }
\end{array}
$$

2. Pembentukan Anhidrida Asam

Molekul air dikeluarkan di antara dua molekul asam, maka akan terbentuk anhidrida asimetris (bila kedua asamnya sama) atau anhidrida campuran (bila kedua asamnya berbeda).

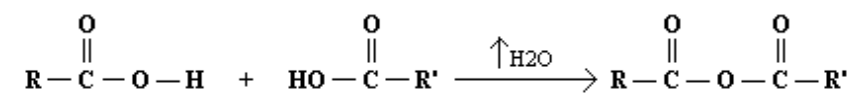

asam karboksilat asam karboksilat anhidridaasimetris

3. Pembentukan Garam

Asam karboksilat bereaksi secara stoikiometri (ekivalen demi ekivalen) dengan basa ( $\mathrm{Na}$ atau $\mathrm{K}$ ) membentuk garam-garam dari $\mathrm{Na}$ atau $\mathrm{K}$.

4. Pembentukan Amida

Pengeluaran molekul air antara asam karboksilat dan amonia atau amina membentuk amida. Amida yang penting adalah peptida yang dibentuk dari gugus 
karboksil suatu asam amino dengan gugus amino dari asam amino lainnya.

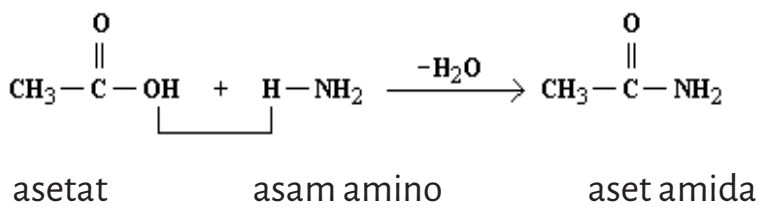

\section{d. Amina}

Amina merupakan derivat alkil dari amonia. Amina berupa gas atau cairan yang mudah menguap dengan bau yang menyerupai amonia tetapi lebih amis.

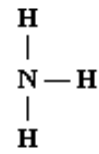

amonia<smiles>[R]N</smiles>

amonia primer<smiles>[R]N[R]</smiles>

amonia sekunder<smiles>[R]N([Y7])[3H]</smiles>

amonia tersier 


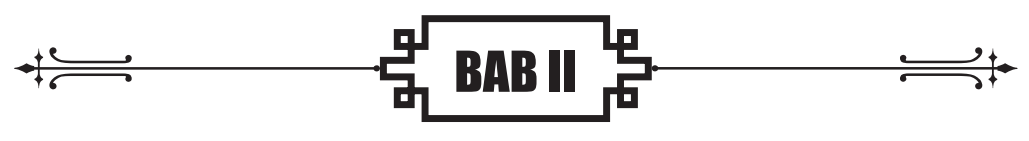

\section{HIR DHN LARUITHN}

\subsection{AIR}

Air merupakan komponen penting bagi kehidupan, baik bagi hewan maupun tumbuh-tumbuhan. Dalam bahan pangan, air berpengaruh pada kenampakan, tekstur, rasa, menentukan kesegaran, dan daya tahan tubuh. Kandungan air berbagai bahan makanan tidak sama, sehingga kaitannya dengan sifat-sifat tersebut juga berbeda. Di dalam sel kebanyakan senyawa dan reaksi biokimia berada dalam lingkungan air. Air penting dalam reaksi biokimia dan menentukan sifat-sifat makromolekuler bahan pangan, misalnya protein. Dalam kehidupan, air berperan sebagai pembawa zat pangan, media reaksi dan sebagainya.

Dalam bahan pangan, baik hewani maupun nabati banyak mengandung air, kecuali beberapa bahan yang dibuat kristal yang hanya mengandung sedikit air, misalnya gula dan garam, dimana airnya hanya ter-absorb-si pada permukaan kristal. Pada sayuran hijau mengandung 90\% air, bahkan lebih. Di dalam tanaman dan hewan, air terdapat di antara sel sebagai cairan interseluler dan air sel yang berada di dalam sel. 
Air di dalam bahan pangan terdapat dalam berbagai bentuk, antara lain:

1. Sebagai air bebas yang terlarut atau terdispersi

contoh: cairan sitoplasma, cairan interseluler, cairan dalam jaringan.

2. Sebagai hidrat

contoh: dalam pati, protein, dan senyawa-senyawa garam organik.

3. Sebagai air yang terimbibisi dalam sel

contoh: pada bahan pangan berdaya serap air tinggi, kemudian terjadi swelling misalnya agar-agar.

4. Terabsorbsi pada permukaan zat padat contoh: pada permukaan partikel padat atau kristal.

Air mempunyai karakteristik yang unik, karena mampu berada dalam berbagai bentuk. Molekul-molekul air dapat berada dalam bentuk kristal atau es, dalam bentuk cair atau air, dan dalam bentuk gas, yaitu berupa uap air.

\subsubsection{STRUKTUR MOLEKUL AIR}

Air murni tersusun oleh bagian terbesar berupa $\mathrm{H}_{2}{ }^{16} \mathrm{O}$ dan sebagian kecil antara lain $\mathrm{H}_{2}{ }^{17} \mathrm{O}$ dan $\mathrm{H}_{2}{ }^{18} \mathrm{O}$. Tampak disini bahwa oksigen yang terikat adalah merupakan isotop. Untuk selanjutnya yang dimaksud air murni dalam pembahasan ini dirumuskan sebagai $\mathrm{H}_{2} \mathrm{O}$.

Molekul air mengandung dua atom $\mathrm{H}$ yang berikatan dengan satu atom $\mathrm{O}$ dan merupakan molekul nonlinier. Atom-atom hidrogen dalam molekul air berikatan dengan oksigen melalui 
pasangan elektron-elektron secara kovalen. struktur tiga dimensi dari molekul air mirip dengan tetrahedral, struktur ini dikenal sebagai tetrahedron yang mempunyai sudut lebih kecil daripada tetrahedral. Pada struktur tiga dimensi ini, oksigen berada di pusatnya, sedang hidrogen berada pada dua sudutnya. Antara kedua atom $\mathrm{H}$ tersebut membentuk sudut $105^{\circ}$, sedangkan sudut tetrahedral sebenarnya adalah $109,5^{\circ}$. Oleh karena itu, tetrahedral pada air agak miring atau condong, akibatnya elektron-elektron dalam molekul air tidak tersebar merata. Pada sisi $\mathrm{O}$ yang berhadapan dengan $\mathrm{H}$ banyak tersebar elektron, sehingga pada $\mathrm{O}$ akan terbentuk muatan negatif setempat. Akibat selanjutnya pada sisi $\mathrm{H}$ yang terbuka akan membentuk muatan positif. Sehing ga molekul air bersifat dwikutub atau dipole. Untuk lebih jelasnya dapat diperhatikan pada Gambar 2-1.

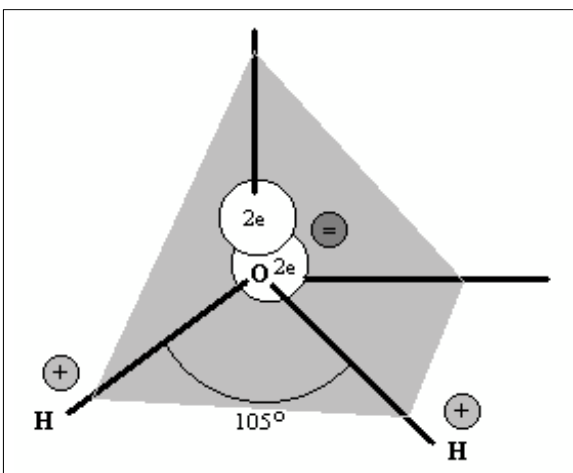

Gambar 2-1: Struktur tetrahedral air

\subsubsection{IKATAN AIR}

Adanya sifat dwikutub dari molekul air akan mendorong hubungan antar molekul air sehingga berikatan satu sama lain. Pengikatan antar molekul air melalui jembatan hidrogen. Ikatan hidrogen antar molekul air ini sangat lemah dibandingkan ikatan kovalen antara hidrogen dan oksigen dalam molekul air yang bersangkutan. Meskipun demikian hal tersebut penting, karena 
akan memberi sifat kepada air sehingga air dapat mengalir. Ikatan hidrogen antara air dengan senyawa berkutub oksigen atau bergugus hidroksil ini akan membentuk hidrat. Ikatan antar molekul air seperti pada Gambar 2-2.

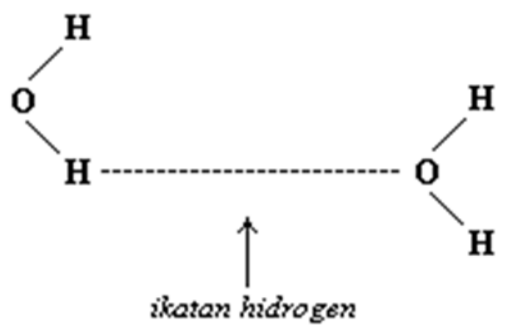

Gambar 2-2: Ikatan dua molekul air

\subsubsection{SIFAT AIR}

Sifat air dapat dikelompokkan menjadi dua kelompok, yaitu perubahan kimia dan perubahan fisika. Perubahan kimia misalnya hidrolisa sukrosa di dalam perut dan hidrolisa trigliserida di dalam intestine atau usus. Perubahan fisika air antara lain titik cair dan titik didih. Air mempunyai sifat fisik yang unik dibandingkan dengan senyawa lain. Apabila air dibandingkan dengan senyawa lain yang mempunyai berat molekul hampir sama, ternyata air mempunyai titik cair paling tinggi, yaitu $0^{\circ} \mathrm{C}$ dan titik didih juga paling tinggi, yaitu $100^{\circ} \mathrm{C}$, sehingga kisaran suhunya paling panjang, yaitu $0^{\circ} \mathrm{C}-100^{\circ} \mathrm{C}$, akibatnya air akan berada pada fase cair dalam berbagai macam suhu. Sebagai perbandingan, untuk beberapa jenis senyawa yang mempunyai berat molekul hampir sama dengan air tersebut disajikan pada Tabel 2-1. 


\section{Tabel 2-1:}

Sifat Fisik air dan senyawa lain berberat molekul rendah

\begin{tabular}{|l|c|c|c|c|}
\hline \multicolumn{1}{|c|}{ Substansi } & Rumus & $\begin{array}{c}\text { Berat } \\
\text { Molekul }\end{array}$ & $\begin{array}{c}\text { Titik Cair } \\
\left({ }^{\circ} \mathrm{C}\right)\end{array}$ & $\begin{array}{c}\text { Titik Didih } \\
\left({ }^{\circ} \mathrm{C}\right)\end{array}$ \\
\hline Metana & $\mathrm{CH}_{4}$ & 16 & -184 & -161 \\
\hline Ammonia & $\mathrm{NH}_{3}$ & 17 & -78 & -33 \\
\hline Air & $\mathrm{H}_{2} \mathrm{O}$ & 18 & 0 & +100 \\
\hline Hidrogen fluorida & $\mathrm{HF}$ & 20 & -83 & +20 \\
\hline Hidrogen sulfida & $\mathrm{H}_{2} \mathrm{~S}$ & 34 & -86 & -61 \\
\hline Hidrogen klorida & $\mathrm{HCl}$ & 36 & -115 & -85 \\
\hline Oksigen & $\mathrm{O}_{2}$ & 36 & & -183 \\
\hline Nitrogen & $\mathrm{N}_{2}$ & 28 & & -196 \\
\hline
\end{tabular}

Pada suhu tertentu terjadi penyimpangan yang disebut anomali dari sifat fisika air. Anomali tersebut adalah apabila suhu air diturunkan sampai $4^{\circ} \mathrm{C}$, maka air akan melepaskan panasnya. Akibatnya gerakan molekul air makin lambat dan volumenya semakin kecil. Bila suhu diturunkan dari $4^{\circ} \mathrm{C}$ sampai $0^{\circ} \mathrm{C}$, panas dilepaskan lagi sehingga air menjadi es. Setelah suhunya mencapai $0^{\circ} \mathrm{C}$ akan terjadi kristal dan saat ini volumenya mendadak mengembang kurang lebih 110\%-nya.

Mengembangnya volume ini karena antar molekul air tersusun dalam bentuk heksagonal simetris, sehingga terbentuk ruangan-ruangan dalam kristal es berupa saluran-saluran dalam jumlah sangat banyak. Oleh karena itu, volumenya mengembang. Gambar bentuk ikatan antar molekul air dalam kristal es seperti disajikan pada Gambar 2-3. 


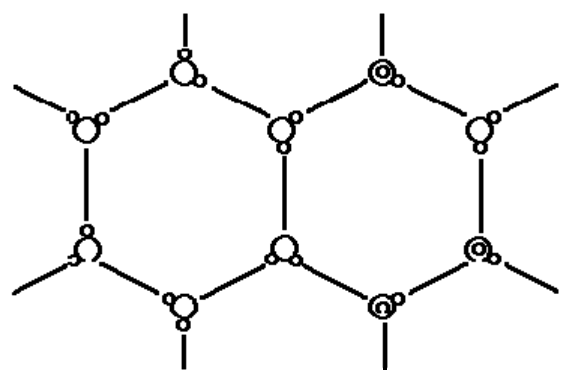

Gambar 2-3: Ikatan antar molekul air dalam es

\subsubsection{DISOSIASI AIR}

Konstanta disosiasi adalah kecenderungan asam dan basa lemah untuk berionisasi. Ionisasi air akan menghasilkan ion $\mathrm{H}^{+}$ dan ion $\mathrm{OH}^{-}$.

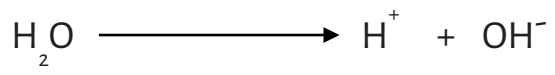

Ion yang terbentuk akan segera bergabung kembali membentuk molekul dan sebaliknya. Artinya suatu saat ia (hidrogen atau oksigen) adalah sebagai ion dan di saat lain ia (hidrogen atau oksigen) sebagai bagian molekul. Kemungkinan atau peluang hidrogen sebagai ion adalah $1,8 \times 10^{-9}$ atau 1,8 perbiliun kejadian. Sehingga kemungkinan hidrogen sebagai ion sangat kecil sekali. Oleh karena itu, hidrogen hampir selalu berada sebagai bagian dari molekul. Artinya pada setiap saat terdapat satu ion hidrogen dan satu ion hidroksil dalam 1,8 x $10^{-9}$ molekul air. Kecenderungan air untuk berdisosiasi dirumuskan sebagai berikut.

$$
\left.\mathrm{K}=\underline{\left[\mathrm{H}^{+}\right.}\right]\left[\mathrm{OH}^{-}\right]
$$

$$
\left[\mathrm{H}_{2} \mathrm{O}\right]
$$




\section{Keterangan:}

$\left[\mathrm{H}^{+}\right] \quad=$ konsentrasi ion $\mathrm{H}^{+}$aktif

$\left[\mathrm{OH}^{-}\right]=$konsentrasi ion $\mathrm{OH}^{-}$aktif

$\left[\mathrm{H}_{2} \mathrm{O}\right]=$ konsentrasimolekul $\mathrm{H}_{2}$ Oyangtidak berdisosiasi

$\mathrm{K}=$ konstanta disosiasi $\left(=\mathrm{K}_{\mathrm{dis}}\right)$

Untuk menghitung konstanta disosiasi air (1 liter air) sebagai berikut:

Berat 1 liter air $=$ Volume $(\mathrm{ml}) \times$ Berat Jenis

$$
\begin{aligned}
& =(1.000 \times 1) \text { gram } \\
& =1.000 \text { gram }
\end{aligned}
$$

Konsentrasi 1 liter air $=$ Berat 1 liter air (gram) : Berat Molekul air

$$
\begin{aligned}
& =(1.000: 18) \text { molar } \\
& =55,56 \mathrm{M}
\end{aligned}
$$

Konsentrasi $\mathrm{H}$ dalam 1 liter air, adalah:

$$
\begin{aligned}
& =\text { Konstanta disosiasi } \mathrm{H}^{+} \times \text {Konsentrasi } 1 \text { liter air } \\
& =\left(1,8 \times 10^{-9}\right) \times 55,56 \text { molar } \\
& 》 100 \times 10^{-9} \text { molar } \\
& =10^{-7} \mathrm{M}
\end{aligned}
$$

Konsentrasi $\mathrm{OH}^{-}=$Konsentrasi $\mathrm{H}^{+}$

$$
=10^{-7} \mathrm{M}
$$

$$
\begin{aligned}
& \mathrm{K}=\frac{\left[\mathrm{H}^{+}\right]\left[\mathrm{OH}^{-}\right]\left[\mathrm{H}_{2} \mathrm{O}\right]}{=} \\
& =\left(10^{-7} \times 10^{-7}\right) / 55,56 \text { molar } \\
& =10^{-14} / 55,56 \text { molar } \\
& =0,018 \times 10^{-14} \text { molar } \\
& =1,8 \times 10^{-16} \mathrm{M}
\end{aligned}
$$


Pengukuran ionisasi untuk air digunakan konstanta $\mathrm{K}_{\mathrm{w}}$ (ionization constant of water), yang dijabarkan dari rumus $\mathrm{K}$ di atas sebagai berikut.

$$
\begin{aligned}
& \mathrm{K}=\frac{\left[\mathrm{H}^{+}\right]\left[\mathrm{OH}^{-}\right]}{\left[\mathrm{H}_{2} \mathrm{O}\right]} \\
& \mathrm{Kx}\left[\mathrm{H}_{2} \mathrm{O}\right]=\left[\mathrm{H}^{+}\right]\left[\mathrm{OH}^{-}\right]
\end{aligned}
$$

dimana $K_{x}\left[\mathrm{H}_{2} \mathrm{O}\right]$ disebut $K_{w}$ jadi:

$$
\begin{aligned}
\mathrm{K}_{w} & =\mathrm{K} \times\left[\mathrm{H}_{2} \mathrm{O}\right] \\
& =\left(1,8 \times 10^{-16} \mathrm{M}\right) \times 55,56 \mathrm{M} \\
& =100 \times 10^{-16} \mathrm{M}^{2} \\
& =10^{-14} \mathrm{M}^{2}
\end{aligned}
$$

danjuga :

$$
\begin{aligned}
\mathrm{K}_{w} & =\left[\mathrm{H}^{+}\right]\left[\mathrm{OH}^{-}\right] \\
& =10^{-14}
\end{aligned}
$$

Nilai $\mathrm{K}_{\mathrm{w}}$ pada berbagai suhu disajikan pada Tabel 3-2. Untuk menentukan titik netral atau $\mathrm{pH}$ netral digunakan basis suhu $22^{\circ} \mathrm{C}$ dimana nilai $\mathrm{K}_{w}=1,01 \times 10^{-14}$ dan konsentrasi ion $\mathrm{H}^{+}$atau $\mathrm{OH}^{-}$ adalah $1,00 \times 10^{-7}$.

\section{Tabel 2-2: Nilai $K_{w}$ pada berbagai suhu}

\begin{tabular}{|c|c|c|}
\hline Suhu $\left({ }^{\circ} \mathbf{C}\right)$ & $\mathbf{K w}$ & {$\left[\mathrm{H}^{+}\right]=\left[\mathrm{OH}^{-}\right]=\sqrt{ } \mathbf{K}_{\mathbf{w}}$} \\
\hline 0 & $0,05 \times 10^{-14}$ & $0,22 \times 10^{-7}$ \\
\hline 2 & $0,16 \times 10^{-14}$ & $0,40 \times 10^{-7}$ \\
\hline 16 & $0,63 \times 10^{-14}$ & $0,79 \times 10^{-7}$ \\
\hline 20 & $0,86 \times 10^{-14}$ & $0,93 \times 10^{-7}$ \\
\hline 22 & $1,01 \times 10^{-14}$ & $1,00 \times 10^{-7}$ \\
\hline 25 & $1,27 \times 10^{-14}$ & $1,13 \times 10^{-7}$ \\
\hline 37 & $3,13 \times 10^{-14}$ & $1,77 \times 10^{-7}$ \\
\hline 40 & $3,80 \times 10^{-14}$ & $1,95 \times 10^{-7}$ \\
\hline 75 & $16,90 \times 10^{-14}$ & $4,11 \times 10^{-7}$ \\
\hline 100 & $48,00 \times 10^{-14}$ & $6,93 \times 10^{-7}$ \\
\hline
\end{tabular}


Rumus tersebut akan berguna pada perhitungan nilai $\mathrm{pH}$ dari larutan asam dan basa dalam air. Hal ini akan digunakan dalam pembahasan tentang sifat kimia larutan.

\subsection{LARUTAN}

Larutan adalah campuran homogen yang terdiri dari dua substansi atau lebih dimana bagian terlarutnya berupa ion atau molekul. Larutan terdiri dari solvent atau zat pelarut dan solute atau zat terlarut. Pada umumnya bagian larutan yang berjumlah banyak disebut pelarut dan yang berjumlah sedikit disebut terlarut. Baik solvent maupun solute dapat berbentuk padat, cair, dan gas. Beberapa contoh larutan beserta solvent dan solute penyusunnya disajikan dalam Tabel 3-3.

\section{Tabel 2-3: Berbagai tipe larutan}

\begin{tabular}{|c|c|l|}
\hline Solute & Solvent & \multicolumn{1}{|c|}{ Contoh } \\
\hline gas & gas & udara $\left(\mathrm{N}_{2}, \mathrm{H}_{2}, \mathrm{O}_{2}\right.$, dst. $)$ \\
\hline gas & cair & soft drink $\left(\mathrm{CO}_{2}\right.$ dalam air) \\
\hline gas & padat & $\mathrm{H}_{2}$ dalam platina \\
\hline cair & cair & larutan cuka \\
\hline cair & padat & Hg dalam emas \\
\hline padat & cair & larutan gula \\
\hline padat & padat & kuningan $(\mathrm{Zn}$ dalam $\mathrm{Cu})$ \\
\hline
\end{tabular}

\subsubsection{JENIS LARUTAN}

Seperti dijelaskan di atas bahwa solute dapat berbentuk ion atau molekul. Berdasarkan bentuk-nya, maka larutan dibedakan menjadi larutan ionik dan larutan molekuler. 


\section{a. LARUTAN IONIK}

Larutan ionik terbentuk apabila solute terdispersi ke dalam solvent dalam bentuk ion.

Misalnya larutan $\mathrm{NaCl}$ larut dalam air.

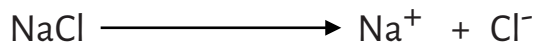

Molekul-molekul air dapat memperkecil daya tarik menarik antara $\mathrm{Na}^{+}$dan $\mathrm{Cl}^{-}$. Ion-ion tersebut kemudian terhidrasi, selanjutnya diungsikan oleh molekul-molekul air, sehingga $\mathrm{NaCl}$ larut dalam air atau garam larut dalam air.

\section{b. LARUTAN MOLEKULER}

Larutan molekuler terbentuk apabila solute terdispersi (tersebar) ke dalam solvent dalam bentuk molekul. Misalnya gula larut dalam air. Pada permukaan kristal gula terdapat gugus polar molekul gula. Kemudian gugus polar ini bergabung dengan molekul air melalui jembatan hidrogen. Peristiwa ini berlangsung terus sehingga seluruh permukaan molekul gula terselubungi air dan masing- masing molekul gula memisahkan diri dari kristal. Akibatnya gula larut dalam air.

Peningkatan suhu akan meningkatkan kelarutan gula, karena naiknya suhu menyebabkan ikatan antara molekul air melemah sehingga air mempunyai energi lebih tinggi. Peningkatan energi yang dimiliki air tersebut akan mempermudah untuk dapat mengatur daya tarik menarik antar molekul gula dalam kristal. Sehingga daya larut gula meningkat.

Berdasarkan ukuran dari bahan terlarutnya, maka larutan dapat dibedakan menjadi: larutan, koloid, dan suspensi. 


\section{a. LARUTAN}

Partikel-partikel terdispersi yang ukurannya kurang dari $1 \mathrm{~mm}$ akan membentuk larutan. Kelarutan suatu bahan akan menurun apabila terjadi agregasi antar molekul-molekul atau ion-ion dalam larutan. Adanya agregasi akan memperbesar ukuran partikel, hingga pada ukuran tertentu ( $>1 \mathrm{~mm}$ ) partikel tersebut tidak melarut lagi. Contoh kejadian ini misalnya pada denaturasi protein oleh panas pada protein terlarut. Proses agregasi ini disebut proses kondensasi. Sebaliknya partikel yang besar dapat dipecah menjadi partikel lebih kecil melalui cara mekanis, elektronis, atau kimiawi. Misalnya koagulasi albumin telur melalui perlakuan kimiawi dengan penambahan pepsin pada putih telur akan membentuk larutan koloid, peristiwa ini disebut peptisasi. Hubungan ketiga jenis larutan ini dapat dibagankan seperti Cambar 2-4.

\section{Gambar 2-4: Hubungan antara suspensi, koloid, dan suspensi}

dispersi

\begin{tabular}{ccc}
\hline $\begin{array}{c}\text { dispersi kasar } \\
\text { (suspensi) }\end{array}$ & $\begin{array}{c}\text { dispersi koloid } \\
\text { (koloid) } \\
>100 \mathrm{~mm}\end{array}$ & $\begin{array}{c}\text { larutan } \\
<1 \mathrm{~mm}\end{array}$ \\
\hline
\end{tabular}

kondensasi

\section{b. KOLOID (LARUTAN KOLOID)}

Koloid terbentuk apabila suatu partikel tidak cukup kecil untuk larut dalam air, tetapi juga tidak cukup besar untuk dapat mengendap, maka akan membentuk suatu dispersi koloid atau 
larutan koloid atau koloid. Contoh koloid misalnya protein, gelatin, susu yang menggumpal (hal ini terjadi karena kasein tidak stabil).

\section{c. SUSPENSI}

Suspensi terbentuk bila suatu partikel tidak cukup kecil untuk larut dalam air atau partikelnya berupa senyawa kompleks sehingga tidak dapat membentuk koloid, maka akan membentuk suatu suspensi. Contoh suspensi antara lain pati dalam air dingin.

\subsubsection{KONSENTRASI}

Konsentrasi dapat diekspresikan dalam berbagai bentuk antara lain:

a. $\operatorname{MOLAR}(M)$

Molar adalah banyaknya grammolekul zat yang terlarut dalam satu liter larutan. Molar atau disinkat $M$ atau gramol atau gmol adalah satuan konsentrasi, dimana $1 M=6,023 \times 10^{23}$ partikel, besaran tersebut merupakan bilangan Avogadro.

Jadi:

$\boldsymbol{x} M=\boldsymbol{x}$ gramol zat $/$ liter larutan

$=\boldsymbol{x} \times$ (gram zat $/ \mathrm{BM}$ zat) / liter larutan

$=\boldsymbol{x} \times 6,023 \times 10^{23}$ partikel / liter

$=\boldsymbol{x}$ gramekivalen $\times n$ zat $/$ liter larutan

$\begin{array}{ll}\text { gramol } & =\text { gramzat } / \text { BM zat } \\ 1 \text { gramol } & =6,023 \times 10^{23} \text { partikel } \\ \text { gramol } & =\text { gramekivalenzat } x \text { ion valensizat } \\ n & =\text { valensizat }\end{array}$


b. $\operatorname{MOLAL}(\mathrm{m})$

Molal adalah banyaknya gramol zat yang terlarut dalam 1.000 gram pelarut.

Jadi:

$\boldsymbol{x} \mathrm{m}=\boldsymbol{x}$ gramol zat $/ 1.000$ gram pelarut

$=\boldsymbol{x}$ (gram zat $/ \mathrm{BM}$ zat $) / 1.000$ gram pelarut

$=\boldsymbol{x}\left(6,023 \times 10^{23}\right.$ partikel $) / 1.000$ gram pelarut

$=\boldsymbol{x}$ grek $\times n$ zat $/ 1.000$ gram pelarut

\section{c. PERSEN BERAT (\% BERAT)}

Persen berat adalah banyaknya gram zat yang terlarut dalam 100 gram larutan (w/wdry basis).

Jadi:

$\boldsymbol{x} \%$ berat $=\boldsymbol{x}$ gram zat $/ 100$ gram pelarut

d. PERSEN VOLUME (\% VOLUME)

Persen volume adalah banyaknya gram zat yang terlarut dalam 100 mililiter larutan.

Jadi:

$\boldsymbol{x} \%$ vol. $=\boldsymbol{x}$ gram zat $/ 100$ mililiter pelarut

e. NORMALITAS $(\mathrm{N})$

Normalitas adalah banyaknya gramekivalen zat yang terlarut dalam satu liter larutan. 
Jadi:

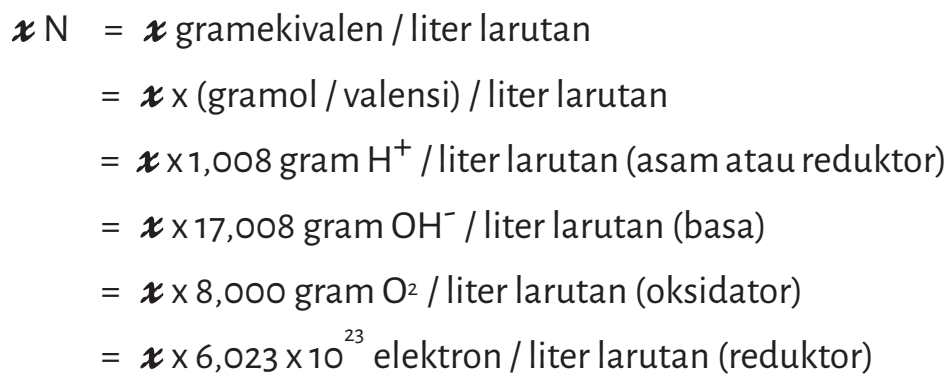

\subsubsection{SIFAT KIMIA LARUTAN}

\section{a. ASAM DAN BASA}

Asiditas dan alkalinitas kaitannya dengan bahan pangan sangat penting, karena warna, tekstur, dan daya simpan bahan pangan sangat peka terhadap perubahan konsentrasi ion hidrogen. Terjadinya perubahan konsentrasi ion hidrogen berarti terjadi perubahan keasaman atau kebasaan, dengan kata lain terjadi perubahan $\mathrm{pH}$.

Menurut Bronsted dan Bjerrum, yang dimaksud asam adalah zat yang m,enghasilkan proton, dan basa adalah zat yang menerima proton. Sedang menurut Lewis, yang dimaksud asam adalah zat yang menerima elektron, dan basa adalah zat yang menghasilkan elektron. Konsep lain kaitannya dengan $\mathrm{pH}$, yang dimaksud asam adalah zat yang menghasilkan ion $\mathrm{H}^{+}$di dalam larutan, sedangkan basa adalah zat yang menghasilkan ion $\mathrm{OH}^{-}$ di dalam larutan.

Contoh: $\mathrm{HCl} \longrightarrow \mathrm{H}^{+}+\mathrm{Cl}^{-}$

(asam kuat, terdisosiasi sempurna) 
$\mathrm{CH}_{3} \mathrm{COOH} \longrightarrow \mathrm{CH}_{3} \mathrm{COO}^{-}+\mathrm{H}^{+}$

(asam lemah, terdisosiasi 1,3\%)

$\mathrm{NaOH}$

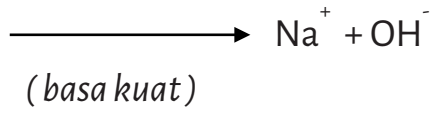

$\mathrm{NH}_{4} \mathrm{OH}$

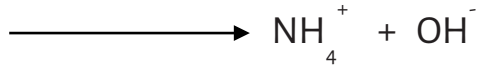

(basalemah)

Perlu diketahui bahwa pada umumnya $\mathrm{H}^{+}$yang dihasilkan tidak terdapat dalam keadaan bebas, tetapi berada dalam keadaan terhidrat, misalnya:

$$
\mathrm{H}_{2} \mathrm{O}+\mathrm{HCl} \longrightarrow \mathrm{H}_{3} \mathrm{O}^{+}+\mathrm{Cl}^{-}
$$

Pada contoh di atas $\mathrm{H}^{+}$yang dihasilkan terhidrat membentuk ion $\mathrm{H}_{2} \mathrm{O}^{-}$atau ion hidronium. Menurut Bronsted, asam adalah zat yang melepaskan proton, dan basa adalah zat yang mengambil proton. Kalau diperhatikan reaksi asam A berikut ini:

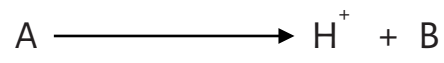

Maka dalam hal ini, $B$ adalah basa karena mengambil proton. Pasangan asam $A$ dan basa $B$ ini disebut pasangan asam-basa konyugasi, yaitu satu melepas ion $\mathrm{H}^{+}$dan lainnya mengambil ion $\mathrm{H}^{+}$.

b. DERAJAT KEASAMAN DAN KEBASAAN

1). DERAJAT KEASAMAN

Derajat keasaman ditunjukkan oleh banyaknya ion $\mathrm{H}^{+}$ yang terdapat dalam larutan atau besarnya konsentrasi $\mathrm{H}^{+}$ 
dalam larutan. Derajat keasaman dinyatakan dengan $\mathrm{pH}$ yang didefinisikan sebagai logaritma negatifdari konsentrasi ion hidrogen.

Rumus: $\mathrm{pH}=-\log \left[\mathrm{H}^{+}\right]$

Bahan yang asam banyak mengandung $\mathrm{H}^{+}$, karena bahan asam adalah penghasil ion $\mathrm{H}^{+}$. Akibatnya, bahan asam mempunyai $\mathrm{pH}$ rendah kurang dari 7 karena $\left[\mathrm{H}^{+}\right]>7$. Ingat bahwa $\mathrm{pH}$ netral mempunyai konsentrasi ion $\mathrm{H}^{+}=10^{-7}$, hal ini telah dibahas dalam pokok bahasan disosiasi air.

Contoh:

1). Berapa $\mathrm{pH}$ larutan yang mempunyai konsentrasi ion hidrogen $=3,2 \times 10^{-4}$ molar?

Penyelesaian:

$$
\begin{aligned}
\mathrm{pH} & =-\log \left[\mathrm{H}^{+}\right] \\
& =-\left(\log 3,2+\log 10^{-4}\right) \\
& =-0,5+4 \\
& =3,5
\end{aligned}
$$

2). Berapa $\mathrm{pH}$ larutan campuran yang terdiri dari larutanlarutan yang mempunyai $\mathrm{pH}=4 \mathrm{dan} \mathrm{pH}=5$

\section{Penyelesaian:}

$$
\begin{aligned}
\text { larutan } \mathrm{pH} & =4, \text { artinya }\left[\mathrm{H}^{+}\right]=10^{-4}=10 \times 10^{-5} \\
\text { larutan } \mathrm{pH} & =5, \text { artinya }\left[\mathrm{H}^{+}\right]=10^{-5}=1 \times 10^{-5} \\
{\left[\mathrm{H}^{+}\right] \text {rata-rata } } & =\left\{\left(10 \times 10^{-5}\right)+\left(1 \times 10^{-5}\right)\right\} / 2 \\
& =\left\{11 \times 10^{-5}\right\} / 2 \\
& =5,5 \times 10^{-5}
\end{aligned}
$$




$$
\begin{aligned}
\mathrm{pH} \text { campuran } & =-\log \left(5,5 \times 10^{-5}\right) \\
& =-\log 5,5-\log 10^{-5} \\
& =-0,740+5 \\
& =4,26
\end{aligned}
$$

Catatan:

pH campuran $\neq 1 / 2(4+5) \neq 4,5$

\section{2). DERAJAT KEBASAAN}

Derajat kebasaan ditunjukkan oleh banyaknya ion $\mathrm{OH}^{-}$ yang terdapat dalam larutan atau besarnya konsentrasi $\mathrm{OH}^{-}$ dalam larutan. Derajat kebasaan dinyatakan dengan $\mathrm{pOH}$ yang didefinisikan sebagai logaritma negatif dari konsentrasi ion hidroksil.

\section{Rumus: $\mathrm{pOH}=-\log \left[\mathrm{OH}^{-}\right]$}

Bahan basa atau alkali konsentrasi $\mathrm{OH}^{-}$nya tinggi, karena bahan basa adalah penghasil ion $\mathrm{OH}^{-}$. Akibatnya konsentrasi $\mathrm{H}^{+}$rendah, sehingga $\mathrm{pH}$-nya tinggi. Hal ini dapat diperjelas menggunakan rumus $\left[\mathrm{H}^{+}\right] \times\left[\mathrm{OH}^{-}\right]=10^{-14}$ atau $\left[\mathrm{H}^{+}\right]=10^{-14} /[\mathrm{OH}]$. Semakin besar $\left[\mathrm{OH}^{-}\right]$yang tentunya di atas netral artinya $\left[\mathrm{OH}^{-}\right.$ ]$>10^{-7}$, sehingga $\left[\mathrm{H}^{+}\right]<10^{-7}$ jadi $\mathrm{pH}$ basa $>7$.

Contoh:

Berapa $\mathrm{pH}$ larutan yang konsentrasi ion hidroksidanya 4,0 x $10^{-4}$ molar?

\section{Penyelesaian:}

$$
\begin{array}{ll}
\mathrm{K}_{\mathrm{w}}=\left[\mathrm{H}^{+}\right]\left[\mathrm{OH}^{-}\right] & =10^{-14} \\
-\log \left[\mathrm{H}^{+}\right]+\left(-\log \left[\mathrm{OH}^{-}\right]\right) & =-\log 10^{-14} \\
\mathrm{pH}+\mathrm{pOH} & =14
\end{array}
$$


diketahui $\left[\mathrm{OH}^{-}\right]$

maka $\mathrm{pOH}$

$\begin{array}{ll}\text { karena } & \mathrm{pH} \\ \text { Jadi: } & \mathrm{pH}\end{array}$

$$
\begin{aligned}
& =4,0 \times 10^{-4} \\
& =-\log \left(4,0 \times 10^{-4}\right) \\
& =-\log 4,0-\log 10^{-4} \\
& =-0,60+4 \\
& =3,4 \\
& =14 \\
& =14-\mathrm{pOH} \\
& =14-3,4 \\
& =10,6
\end{aligned}
$$

\section{c. BUFFER}

Buffer adalah larutan yang apabila kepadanya ditambahkan sejumlah kecil asam atau basa, maka tidak akan mengalami perubahan $\mathrm{pH}$. Buffer merupakan campuran asam lemah dengan garamnya atau basa lemah dengan garamnya.

Contoh: Campuran asam lemah dengan garamnya.

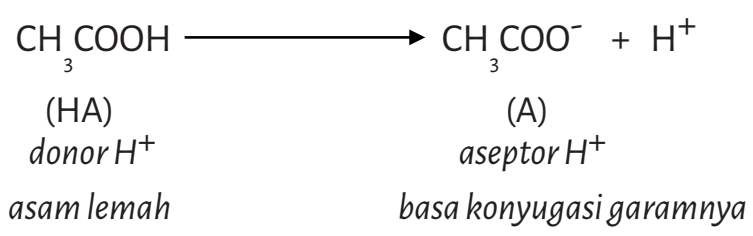

Campuran basa lemah dengan garamnya.

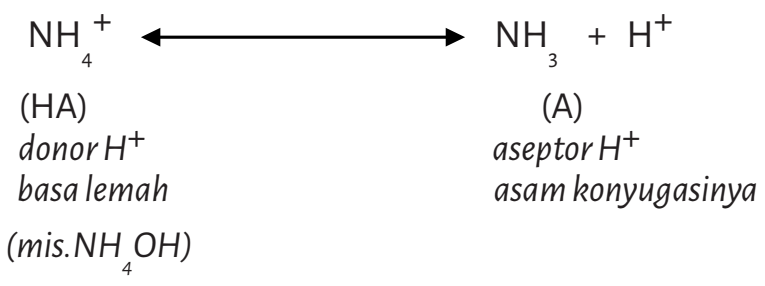


Suatu buffer harus terdapat donor $\mathrm{H}^{+}$dan aseptor $\mathrm{H}^{+}$secara bersama-sama untuk mempertahankan $\mathrm{pH}$ konstan. Sehingga secara matematis dapat dirumuskan sebagai berikut.

HA

donor elektron
$\mathrm{H}^{+}+\mathrm{A}^{-}$

asam konyugasinya

$$
\begin{array}{ll}
\mathrm{Ka} & =\frac{\left[\mathrm{H}^{+}\right]\left[\mathrm{A}^{-}\right]}{[\mathrm{HA}]} \\
\mathrm{Ka} & =\left[\mathrm{H}^{+}\right] \times \frac{\left[\mathrm{A}^{-}\right]}{[\mathrm{HA}]} \\
{\left[\mathrm{H}^{+}\right]} & =\mathrm{KAx} \frac{[\mathrm{HA}]}{[\mathrm{A}-]} \\
-\log \left[\mathrm{H}^{+}\right] & =\log \mathrm{Ka}+\left\{-\log \frac{[\mathrm{HA}]}{[\mathrm{A}-]}\right\} \\
& =\log \mathrm{Ka}-\log \frac{[\mathrm{HA}]}{[\mathrm{A}-]} \\
\mathrm{PH} & =\log \mathrm{Ka}+\log \frac{[\mathrm{A}-]}{[\mathrm{HA}]} \\
& =\mathrm{pKa}+\log \frac{[\mathrm{A}]}{}
\end{array}
$$

$$
\begin{aligned}
{\left[\mathrm{A}^{-}\right] } & =\text {konsentrasigaram (grol) } \\
& =\text { grek } \times \text { valensi } \\
& =\text { volume } \times \mathrm{N} \times \text { valensi } \\
{[\mathrm{HA}] } & =\text { konsentrasiasam } \\
& =\text { volume } \times \mathrm{N} \times \text { valensi }
\end{aligned}
$$


Contoh:

Hitunglah $\mathrm{pH}$ buffer suatu larutan buffer yang terdiri dari

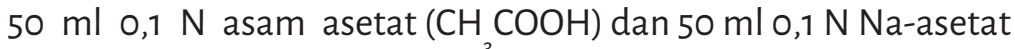
$\left(\mathrm{CH}_{3} \mathrm{COONa}\right)$, apabila diketahui $\mathrm{Ka}=1,75 \times 10^{-5}$. Berapa $\mathrm{pH}$ buffer apabila ke dalam larutan tersebut ditambahkan $1 \mathrm{ml} \mathrm{HCl} \mathrm{o,1} \mathrm{N}$ ?

\section{Penyelesaian:}

Sebelum ditambah $1 \mathrm{ml} \mathrm{HCl} \mathrm{0,1} \mathrm{N.}$

Rumus:

$$
\begin{aligned}
-\log \left[\mathrm{H}^{+}\right) & =-\log \mathrm{Ka}+\log \frac{\left[\mathrm{A}^{-}\right]}{[\mathrm{HA}]} \\
\mathrm{pH} & =-\log \left(1,75 \times 10^{-5}\right)+\log \frac{50 \times 0,1 \times 1}{50 \times 0,1 \times 1} \\
& =-\log 1,75-\log 10^{-5}+\log 1 \\
& =0,24+5+0 \\
& =+4,75
\end{aligned}
$$

$\left[\mathrm{A}^{-}\right]=$konsentrasi $\mathrm{CH}_{3} \mathrm{COONa}_{3}$

$$
=\text { volume } \times \mathrm{N} \times \text { valensi }
$$$$
=50 \times 0,1 \times 1
$$

$[\mathrm{HA}]=$ konsentrasi $\mathrm{CH}_{3} \mathrm{COOH}$

$$
=\text { volume } \times \mathrm{N} \times \text { valensi }
$$$$
=50 \times 0,1 \times 1
$$

Sesudah ditambah $1 \mathrm{ml} \mathrm{HCl} \mathrm{0,1} \mathrm{N}$.

Reaksi: $\mathrm{HCl}+\mathrm{CH}_{3} \mathrm{COONa} \longrightarrow \mathrm{CH}_{3} \mathrm{COOH}+\mathrm{NaCl}$

$$
1 \mathrm{ml} \quad(50-1=49) \mathrm{ml} \quad(50+1=51) \mathrm{ml}
$$




$$
\begin{aligned}
\text { Rumus: }-\log \left[\mathrm{H}^{+}\right) & =-\log \mathrm{Ka}+\log \frac{\left[\mathrm{A}^{-}\right]}{[\mathrm{HA}]} \\
\mathrm{pH} & =-\log \left(1,75 \times 10^{-5}\right)+\log \frac{49 \times 0,1 \times 1}{51 \times 0,1 \times 1} \\
& =-\log 1,75-\log 10^{-5}+\log \frac{49}{51} \\
& =-\log 1,75-\log 10^{-5}+\log 49-\log 51 \\
& =-0,24+5+1,69-1,71 \\
& =+4,74
\end{aligned}
$$

$$
\begin{aligned}
{\left[\mathrm{A}^{-}\right] } & =\text {konsentrasi } \mathrm{CH}_{3} \mathrm{COONa} \\
& =\text { volume } \times \mathrm{N} \times \text { valensi } \\
& =49 \times 0,1 \times 1 \\
{[\mathrm{HA}] } & =\text { konsentrasi } \mathrm{CH}_{3} \mathrm{COOH} \\
& =\text { volume } \times \mathrm{N} \times \text { valensi } \\
& =51 \times 0,1 \times 1
\end{aligned}
$$

Dari perhitungan, tampak bahwa interval perubahan $\mathrm{pH}=4,76-4,74=0,002$. Perubahan yang sedemikian kecil ini dapat diabaikan, sehingga dapat dianggap pH-nya tetap.[] 



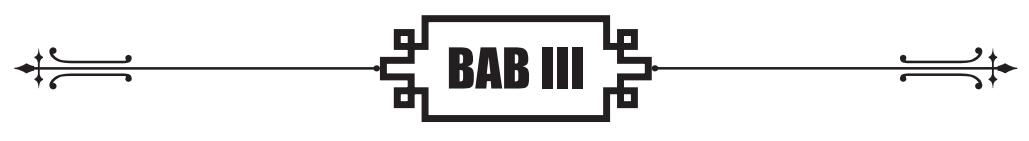

\section{PROTEIN}

Protein berasal dari bahasa Yunani proteosyang artinya utama atau sangat penting. Pada hewan, protein merupakan penyusun otot, kulit, rambut, dan jaringan pengikat. Pada tanaman, protein banyak terdapat dalam kotiledon biji. Ensim dan hormon juga merupakan protein.

Protein mengandung $\mathrm{C}, \mathrm{H}, \mathrm{O}, \mathrm{N}$ beberapa mengandung $\mathrm{S}$, $\mathrm{P}$, dan kadang-kadang $\mathrm{Zn}$, Fe, Cu. Kadarnya bervariasi, dengan komposisi rata-rata: N (16\%), H (7\%), C (50\%), O (22\%), S (0,5$5 \%$ ). Protein disusun terutama oleh asam-asam amino. Apabila protein dihidrolisa oleh asam kuat atau basa kuat atau dengan pertolongan ensim tertentu dapat terdekomposisi sempurna menjadi komponen-komponen penyusunnya. Protein merupakan polipeptida, selain mengandung asam amino juga banyak mengandung bahan bukan asam amino seperti heme, derivat vitamin, lipida, dan karbohidrat. Protein yang mengandung senyawa lain selain asam amino disebut protein kompleks, sedangkan protein yang hanya mengandung asam amino saja disebut protein sederhana. 
Sel hidup menghasilkan berbagai macam makromolekul seperti protein, asam nukleat, dan polisakarida. Senyawa makromolekul tersebut berfungsi sebagai komponen struktural, biokatalisator, hormon, reseptor, dan sebagai tempat menyimpan informasi genetik. Protein makromolekuler merupakan biopolimer yang dibentuk dari unit monomer. Unit monomer protein berupa asam amino.

\subsection{ASAM AMINO}

Asam amino mempunyai dua gugus fungsional, yaitu gugus asam amino dan gugus asam karboksilat. Pada asam a-amino kedua gugus fungsional tersebut terikat pada atom C-a yang sama, seperti diperlihatkan pada Gambar 3-1. Protein pada umumnya disusun oleh asam a-amino.<smiles>[R]C(N)C(=O)O</smiles><smiles>[R]C(N)C(=O)O</smiles>

\section{Gambar 3-1: Struktur asam $\alpha$-amino}

Dari gambar di atas tampak bahwa asam $\alpha$-amino disusun oleh empat gugus yang berbeda-beda yang terikat pada $\mathrm{C}-\alpha$ kecuali glisin karena pada glisin gugus $\mathrm{R}$ adalah berupa atom $\mathrm{H}$. Cugus- gugus penyusun asam amino tersebut adalah $\mathrm{R}, \mathrm{NH}_{2}, \mathrm{COOH}$, atom $\mathrm{H}$. Keempat gugusyang terikat pada C-aitu berbeda-beda menyebabkan asam amino mempunyai aktifitas optik. Hampir semua asam amino bersifat L (levorotatori), meskipun ditemukan pula beberapa asam aminoyang bersifat $\mathrm{D}$ (dextrorotatori) pada $\mathrm{pH}=7,0$. 


\section{SIFAT ASAM-BASA ASAM AMINO}

Pada setiap asam amino terdapat gugus amino sebagai akseptor proton dan gugus karboksilat sebagai donor proton. Dalam larutan, gugus amino berada dalam dua bentuk, yaitu satu dalam bentuk bermuatan dan lainnya dalam bentuk tidak bermuatan, yang keduanya terdapat dalam keseimbangan protonik.

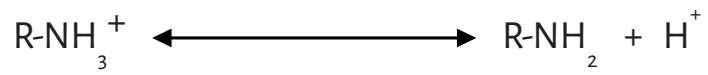

Sedangkan gugus karboksilat dalam kesetimbangan sebagai berikut.

$\mathrm{R}-\mathrm{COOH} \longleftrightarrow \mathrm{R}-\mathrm{COO}^{-}+\mathrm{H}^{+}$

Dalam kesetimbangan di atas tergambarkan bahwa $\mathrm{RNH}_{3}{ }^{+}$ dan $\mathrm{RCOOH}$ merupakan donor proton atau asam. Sedangkan $\mathrm{RNH}_{2}$ dan $\mathrm{RCOO}^{-}$merupakan akseptor proton atau basa konyugasinya dari asam yang bersangkutan atau yang sesuai. Hal ini memberikan ciri yang khas untuk asam amino, yaitu bersifat amfoter. Artinya asam amino dapat bertindak sebagai asam atau basa. Sebenarnya asam amino terdapat dalam zwitterion.<smiles>CC([NH3+])C(=O)[O-]</smiles>

\section{Gambar 3-2: Zwitterion Alanin}

Dalam larutan encer, asam amino dalam kesetimbangan dinamis antara kation, anion, dan zwitterion. Kesetimbangan dinamis tersebut adalah seperti Gambar 3-3 berikut ini. 
<smiles>[R]C([NH3+])C(=O)O</smiles>

(A)

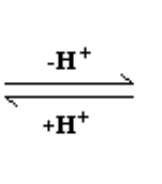

(B)<smiles>[R]C(N)C(=O)[O-]</smiles>

(C)

kation (+) zwitterion anion (-)

Muatan bersih asam amino tergantung pada $\mathrm{pH}$ atau konsentrasi proton larutan sekitarnya. Apabila suatu asam amino yang berada $\mathrm{pH}$ tertentu mempunyai muatan bersih seimbang, artinya jumlah aljabarnya sama dengan nol, maka ia dalam bentuk zwitter ion dan $\mathrm{pH}$-nya disebut $\mathrm{pH}$ isoelektris disingkat pHi. Pada $\mathrm{pH}$ terjadinya isoelektris disebut titik isoelektris. Dalam medium yang mempunyai $\mathrm{pH}$ di bawah $\mathrm{pHi}$, maka yang dominan adalah bentuk kation atau bermuatan positif. Sebaliknya, pada $\mathrm{pH}$ medium di atas pHi, maka yang dominan adalah anion atau bermuatan negatif. Pada titik isoelektris, kelarutan asam amino di dalam medium pelarut sangat kecil bahkan tidak bergerak. Sifat ini kemudian digunakan sebagai dasar untuk identifikasi atau pemisahan asam-asam amino.

$\mathrm{pH}$ isoelektris merupakan pertengahan antara kedua nilai $\mathrm{pK}$ dari kedua jenis isoelektrisnya. Untuk menghitung $\mathrm{pH}$ isoelektris menggunakan rumus sebagai berikut.

$$
\mathrm{pHi} \quad=\mathrm{pl}=1 / 2\left(\mathrm{pK}_{1}+\mathrm{pK}_{2}\right)
$$

Contoh: Dari titrasi asam amino glisin diketahui $\mathrm{pK}_{1}(\mathrm{RCOOH})=$ 2,35 dan $\mathrm{pK}_{2}\left(\mathrm{RNH}_{3}{ }^{+}\right)=9,78$. 
Maka titik isoelektrisnya adalah:

$$
\mathrm{pl} \quad \begin{aligned}
=\mathrm{pHi} & =1 / 2\left(p K_{1}+\mathrm{pK}_{2}\right) \\
& =1 / 2(2,35+9,78) \\
& =6,065
\end{aligned}
$$

Asam amino penyusun protein dengan beberapa sifat fisika dan sifat kimianya disajikan dalam Tabel 4-1. Asam-asam amino merupakan zat padat yang terdiri atas kristal bertitik lebur tinggi. Asam amino tidak larut dalam pelarut nonpolar seperti benzena, heksana, eter dan sebagainya; tetapi larut dalam pelarut polar misalnya pada larutan air atau etanol.

Untuk asam amino yang mengandung lebih dari dua gugus yang dapat berdisosiasi, maka perlu diperhatikan struktur ionnya, perhatikan Tabel 4-1 kolom rumus bangun. Dalam hal ini kita perhatikan rantai samping yang dimilikinya, apakah asam atau basa. Apabila mempunyai rantai samping asam maka $\mathrm{pHi}$ berada pada daerah asam dan sebaliknya apabila mempunyai rantai samping basa maka $\mathrm{pHi}$ berada pada daerah basa.

Tabel 3-1:

\begin{tabular}{|c|c|c|c|c|c|c|c|c|}
\hline Nama & Singkatan & $\begin{array}{l}\text { Titik } \\
\text { lebur } \\
\text { atau } \\
\text { urai }\end{array}$ & $\begin{array}{l}\text { Kela- } \\
\text { rutan } \\
\mathrm{dlm} \text { air } \\
\mathrm{gr} / 100 \\
\mathrm{ml}, \mathrm{pd} \\
25^{\circ} \mathrm{C}\end{array}$ & $\mathrm{pK}_{1}$ & $\mathrm{pK}_{2}$ & $\mathrm{pK}_{3}$ & $\begin{array}{l}\mathrm{pI}= \\
\mathrm{pHi}\end{array}$ & Rumus Bangun \\
\hline 1 & 2 & 3 & 4 & 5 & 6 & 7 & 8 & 9 \\
\hline \multicolumn{9}{|c|}{ Rantai samping alifatik } \\
\hline Glisin & Gly (G) & 223 & 25 & 2,35 & 9,78 & & 6,07 & 的 $-\mathrm{CH}_{2}-\mathrm{COO}^{-}$ \\
\hline Alanin & Ala (A) & 297 & 17 & 2,35 & 9,78 & & 6,07 & $\prod_{\mathrm{CH}}^{\mathrm{CH}}$ \\
\hline
\end{tabular}

\section{Asam-asam amino yang terdapat dalam protein}

Tabel 3-1: Asam-asam amino yang terdapat dalam protein. 


\begin{tabular}{|c|c|c|c|c|c|c|c|c|}
\hline Valin & $\operatorname{Val}(\mathrm{V})$ & 315 & 9 & 2,29 & 9,72 & & 6,00 & 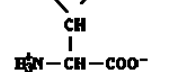 \\
\hline Leusin & Leu (L) & 337 & 2 & 2,33 & 9,74 & & 6,04 & 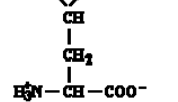 \\
\hline Isoleusin & Ile (I) & 284 & 4 & 2,32 & 9,76 & & 6,04 & $\begin{array}{c}\mathrm{CH}_{3} \\
\mathrm{CH}_{2} \\
I_{\mathrm{CH}}-\mathrm{CH}_{3} \\
I_{\mathrm{HB}}-\mathrm{COO}^{-}\end{array}$ \\
\hline \multicolumn{9}{|c|}{ Rantai samping mengandung gugus hidroksil $(\mathrm{OH})$} \\
\hline Serin & $\operatorname{Ser}(\mathrm{S})$ & 228 & 5 & 2,21 & 9,15 & & 5,68 & $\begin{array}{c}\mathrm{CH}_{2} \mathrm{OH} \\
\mathrm{H} \mathrm{NOH}-\mathrm{COO}^{-}\end{array}$ \\
\hline Treonin & $\operatorname{Thr}(\mathrm{T})$ & 257 & $\begin{array}{l}\text { sangat } \\
\text { tinggi }\end{array}$ & 2,09 & 9,01 & & 5,60 & $\begin{array}{c}\mathrm{CH}_{\mathrm{H}} \\
\mathrm{B}-\mathrm{c}-\mathrm{OH} \\
\left.\right|_{\mathrm{H}} \mathrm{CH}-\mathrm{COO}^{-}\end{array}$ \\
\hline Tirosin & Tyr (Y) & 344 & 0,04 & 2,20 & 9,11 & 10,07 & 5,66 & 助- \\
\hline \multicolumn{9}{|c|}{ Rantai samping mengandung atom belerang ( $S$ ) } \\
\hline Sistein & Cys (C) & & $\begin{array}{l}\text { sangat } \\
\text { tinggi }\end{array}$ & 1,86 & 8,35 & 10,34 & 5,11 & $\begin{array}{c}\mathrm{CH}_{2}-\mathrm{SB} \\
\mathrm{I} \\
\mathrm{H}-\mathrm{CH}-\mathrm{CoO}^{-}\end{array}$ \\
\hline Metionin & $\operatorname{Met}(\mathrm{M})$ & 283 & 3 & 2,28 & 9,21 & & 5,74 & $\begin{array}{c}\mathrm{CH}_{2}-\mathrm{SH}-\mathrm{CH}_{3} \\
\mathrm{CH}_{2} \\
\mathrm{CH}_{2} \\
\mathrm{I} \mathrm{CH}-\mathrm{COO}^{-}\end{array}$ \\
\hline \multicolumn{9}{|c|}{ Rantai samping mengandung gugus asam atau amida } \\
\hline Asam aspartat & Asp (D) & 289 & 0,4 & 2,10 & 3,86 & 9,82 & 2,98 & $\begin{array}{c}\mathrm{COO}^{-} \\
\mathrm{CH}_{2} \\
\mathrm{CH}_{2} \\
\mathrm{CH}_{\mathrm{CH}}-\mathrm{COO}^{-}\end{array}$ \\
\hline Asparagin & Asn $(\mathrm{N})$ & 236 & 2,4 & 2,02 & 8,80 & & 5,41 & $\begin{array}{c}\mathrm{c}-\mathrm{NH}_{2} \\
\mathrm{I} \\
\mathrm{CH}_{2} \\
\mathrm{I}_{\mathrm{N}} \mathrm{CH}-\mathrm{COO}^{-}\end{array}$ \\
\hline Asam glutamat & Glu (E) & 247 & 0,7 & 2,10 & 4,07 & 9,47 & 3,08 & $\begin{array}{c}\mathrm{COO}^{-} \\
\mathrm{CH}_{\mathrm{B}_{2}} \\
\mathrm{CH}_{2} \\
\mathrm{CH}_{\mathbf{2}} \\
\mathrm{CH}-\mathrm{COO}^{-}\end{array}$ \\
\hline Glutamin & $\mathrm{Gln}(\mathrm{Q})$ & 186 & 3,6 & 2,17 & 9,13 & & 3,65 & 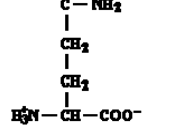 \\
\hline
\end{tabular}




\begin{tabular}{|c|c|c|c|c|c|c|c|c|}
\hline \multicolumn{9}{|c|}{ Rantai samping mengandung gugus basa } \\
\hline Arginin & $\operatorname{Arg}(\mathrm{R})$ & 230 & 15 & 2,01 & 9,04 & 12,48 & 10,76 & 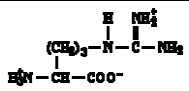 \\
\hline Lisin & Lys (K) & 255 & $\begin{array}{l}\text { sangat } \\
\text { tinggi }\end{array}$ & 2,18 & 8,95 & 10,53 & 9,74 & ${ }_{\mathrm{H}}^{\left(\mathrm{CH}_{\mathrm{N}}-\mathrm{CH}_{4}-\mathrm{CH}_{3}^{*}-\mathrm{COO}^{-}\right.}$ \\
\hline Histidin & His $(\mathrm{H})$ & 287 & 0,4 & 1,77 & 6,10 & 9,18 & 7,64 & ${ }_{\mathrm{CH}}^{\mathrm{C}-\mathrm{NH}_{2}^{\prime}} \mathrm{CH}_{\mathrm{CH}}^{\prime}-\mathrm{COO}^{-}$ \\
\hline \multicolumn{9}{|c|}{ Mengandung cincin aromatik } \\
\hline Histidin & His $(\mathrm{H})$ & 287 & 0,4 & 1,77 & 6,10 & 9,18 & 7,64 & \\
\hline Fenilalanin & Phe (F) & 283 & 3 & 2,58 & 9,24 & & 5,91 & \\
\hline Tyrosin & Tyr (Y) & 344 & 0,04 & 2,20 & 9,11 & 10,07 & 5,66 & 蝶- \\
\hline Triptofan & $\operatorname{Trp}(\mathrm{W})$ & 289 & 1 & 2,38 & 9,39 & & 5,88 & $\left.\right|_{\mathrm{CH}_{2}} ^{\mathrm{I}-\mathrm{CH}_{2}-\mathrm{COO}^{-}}$ \\
\hline \multicolumn{9}{|c|}{ Asam amino } \\
\hline Prolin & Pro (P) & 220 & 162 & 2,00 & 10,60 & & 6,30 & \\
\hline
\end{tabular}

Contoh:

Asam glutamat mempunyai $\mathrm{pK}_{1}=2,00 ; \mathrm{pK}_{2}=4,07 ; \mathrm{pK}_{3}=9,47$ dengan rumus bangun: 
<smiles>[NH3+]C(CCC(=O)[O-])C(=O)[O-]</smiles>

atau<smiles>[NH3+]C(CCC(=O)O)C(=O)[O-]</smiles>

Artinya mempunyai rantai samping asam, maka $\mathrm{pHi}$ berada pada daerah asam:

$$
\begin{aligned}
\mathrm{pl}=\mathrm{pHi} & =1 / 2\left(\mathrm{pK}_{1}+\mathrm{pK}_{2}\right) \\
& =1 / 2(2,10+4,07) \\
& =3,08
\end{aligned}
$$

\subsection{PEPTIDA}

Reaksi terpenting dalam asam amino adalah pembentukan ikatan peptida. Pada prinsipnya pembentukan ikatan peptida adalah penggabungan gugus amino dan gugus karboksil dari dua asam amino dengan membuang satu molekul air.

Unsur asam amino penyusun peptida disebut residu asam amino. Suatu peptida yang terdiri dari dua asam amino atau lebih, antar residu asam amino dihubungkan oleh ikatan peptida (-CO-NH-) atau amida. Penamaan peptida didasarkan kepada banyaknya residu, bukan banyaknya ikatan peptida, misalnya peptida yang disusun oleh tiga residu disebut tripeptida. Peptida yang disusun oleh lebih dari sepuluh residu asam amino disebut polipeptida. Suatu jenis polipeptida mempunyai aktivitas fisiologis tertentu dan apabila dilakukan penggantian satu residu atau lebih, maka dapat mengurangi aktivitas fisiologia dari polipeptida tersebut. 
Menurut perjanjian, struktur peptida ditulis dengan ketentuan: residu N-terminal berada di sebelah kiri dan C-terminal berada di sebelah kanan. Penulisan rumus bangun polipeptida seperti Cambar 4-4 berikut ini.

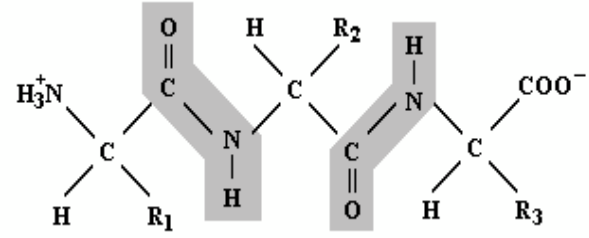

\section{Gambar 3-4: Struktur polipeptida}

Tulang punggungnya berupa rantai zig-zag yang menghubungkan antara gugus-gugus $-\mathrm{NH}_{3}^{+},-\mathrm{COO}^{-}$, dan $\mathrm{C}_{\alpha}$. Cugus $\mathrm{C}_{\alpha}, \mathrm{CO}$, dan $\mathrm{NH}$ letaknya berselang-seling. $\mathrm{R}_{1}, \mathrm{R}_{2}, \mathrm{R}_{3}$ merupakan gugus rantai samping yang sesuai.

Pada umumnya penulisan polipeptida tidak ditulis secara konvensional seperti di atas, tetapi ditulis dengan menggunakan singkatan kimianya, misalnya:

\section{Glu-Lys-(Ala,Clu,Tyr)-His-Ala}

$\mathrm{N}$-terminal

C-terminal

atau ditulis:

\section{E K $(A, E, Y) H A$}

Pada struktur di atas $\mathrm{N}$-terminal berupa Clutamat (Clu atau E) dan C-terminal berupa Alanin (Ala atau A). Antara nama asam amino dengan nama singkatan tiga huruf diberi tanda penghubung $(-)$, sedangkan untuk nama singkatan satu huruf tidak diberi tanda penghubung. Nama-nama yang berada di 
antara tanda kurung melambangkan bahwa strukturnya tidak pasti.

\subsection{PROTEIN}

Protein adalah polipeptida dengan berat molekul tinggi yang terdapat secara alami. Polipeptida yang hanya memiliki asam amino saja disebut protein sederhana, sedangkan polipeptida yang mengandung komponen bukan asam amino disebut protein terkonyugasi. Senyawa bukan asam mino yang terdapat dalam polipeptida disebut gugus prostetis.

\subsubsection{KLASIFIKASI PROTEIN}

Untuk mengklasifikasikan protein secara baku banyak mengalami kesulitan karena protein merupakan sistem yang rumit. Klasifikasi berikut ini mengikuti salah satu dari banyak kriteria yang dapat digunakan untuk pengelompokan protein. Berdasarkan komponen penyusunnya, protein dikelompokkan menjadi protein sederhana dan protein kompleks.

\section{a. PROTEIN SEDERHANA}

Protein sederhana adalah protein yang apabila dihidrolisa hanya akan menghasilkan asam-asam amino atau derivatnya saja. Berdasarkan bentuk dan kelarutannya, maka protein sederhana dikelompokkan menjadi dua, yaitu protein globular dan protein fibrosa.

\section{1). PROTEIN FIBROSA (SCLEROPROTEINS)}

Protein fibrosa adalah protein yang mempunyai rasio aksial (perbandingan panjang terhadap lebar) yang mempunyai nilai 
lebih besar dari 10. Protein fibrosa mempunyai ciri-ciri, antara lain berbentuk benang atau fibriler, derajat kristalisasinya tinggi atau hampir tidak membentuk kristal dan tidak larut dalam pelarut netral atau larutan garam, di samping itu juga tahan terhadap sebagian besar ensim. Contoh kolagen pada jaringan pengikat dan epidermis, serta keratin pada rambut.

\section{2). PROTEIN GLOBULAR (SPHEROPROTEINS)}

Protein globular adalah protein yang mempunyai rasio aksial kurang dari 10 dan umumnya lebih dari 3-4. Protein ini berbentuk bola dan ditandai oleh rantai polipeptida yang penuh lipatan-lipatan dan berbelit. Berdasarkan kelarutannya, masih dikelompokkan lebih lanjut menjadi:

\section{a). ALBUMIN}

Albumin bersifat larut dalam air dan larutan garam. Albumin terkoagulasi oleh panas dan terendapkan oleh amonium sulfat. Contoh ovalbumin dalam putih telur, laktalbumin dalam susu, albumin dalam serum darah, legumetin dalam kacang-kacangan, dan leucosin dalam gandum.

\section{b). GLOBULIN}

Clobulin sedikit larut dalam air dan larut dalam larutan garam (dari asam kuat atau basa kuat). Clobulin terkoagulasi oleh panas. Contoh myosin dalam otot, laktoglobulin dalam susu, glysin dalam kedelai, arachin dan conarachin dalam kacang tanah, plasma globulin dalam darah, ovoglobulin dalam kuning telur, dan legumetin dalam kacang-kacangan. 


\section{c). GLUTELIN}

Clutelin tidak larut dalam pelarut netral tetapi larut dalam larutan asam atau basa. Contoh glutelin dalam gandum, dan oryzenin dalam jagung.

\section{d). PROLAMIN}

Prolamin bersifat larut dalam etanol (50-80)\%. Contoh gliadin dalam gandum, zein dalam jagung, dan hordein dalam barley.

e). HISTONE

Histone larut dalam air, asam/basa encer, dan larutan garam, tetapi tidak larut dalam larutan amonia encer. Contoh histone dalam ikan paus, pankreas dan globin dalam darah.

f). PROTAMIN

Protamin larut dalam etanol $(70-80) \%$, tetapi tidak larut dalam air dan etanol absolut. Protamin bersifat basa kuat, dengan asam akan membentuk garam kuat. Contoh salmin dalam salmon, klupein dalam herring, dan cyprinin dalam karper.

\section{b. PROTEIN KOMPLEKS}

Protein kompleks adalah protein apabila dihidrolisa selain menghasilkan asam-asam amino juga senyawa-senyawa bukan asam amino. Senyawa bukan asam amino sebagai gugus prostetis, misalnya lipida, karbohidrat, asam nukleat dan lain-lain. Pemberian nama protein sesuai dengan gugus prostetis yang ada 
dalam protein, misalnya fosfoprotein, glikoprotein, lipoprotein, dan nukleoprotein.

Fosfoprotein mempunyai gugus prostetis berupa asam fosfat yang terkait dengan gugus hidroksil pada serine dan threonine melalui ikatan ester, misalnya kasein dan vitelin dalam kuning telur. Clikoprotein dan protein polisakarida mempunyai gugus prostetis berupa karbohidrat. Clikoprotein mempunyai gugus prostetis berupa karbohidrat. Clikoprotein mempunyai gugus prostetis oligosakarida, sedang protein polisakarida mempunyai gugus prostetis rantai karbohidrat yang mengandung ratusan residu glikosil. Keduanya sebagai komponen struktural utama pada hewan, misalnya dalam jaringan pengikat tendomucin pada tendon, mucin (muco protein) pada kelenjar mukosa atau kelenjar air liur. Lipoprotein mengandung gugus prostetis berupa lipida terutama lesitin dan kolesterol, misalnya lipoprotein dalam serum darah, kuning telur, susu dan sebagainya. Kromoprotein mengandung gugus prostetis berupa metaloporfirin seperti klorofil atau hemin dalam hemoglobin, termasuk juga ensimensim peroksidase, katalase, sitikrom dan myoglobin pada otot daging. Nukleoprotein dengan gugus prostetis asam nukleat yang berikatan dalam bentuk garam dengan protein.

\subsubsection{STRUKTUR PROTEIN}

Struktur protein dikelompokkan menjadi empat, yaitu: primer, sekunder, tersier, dan kuarterner. Berdasarkan konformasi dan pisisinya dalam molekul, maka struktur protein dikelompokkan menjadi sekunder, tersier, dan kuarterner. Konformasi adalah susunan ruang atom-atom atau gugusgugus rantai polipeptida, sedangkan yang dimaksud posisinya 
yaitu dalam kaitannya dengan hubungan masing-masing dalam molekul protein.

\section{a. STRUKTUR PRIMER}

Struktur primer merupakan protein rantai lurus tidak bercabang yang berikatan melalui peptida secara kovalen. Karena protein struktur primer disusun oleh protein rantai lurus, maka akan diperoleh protein berbentuk sangat panjang dan pipih. Protein struktur primer jarang sekali dijumpai di alam. Protein struktur primer seperti diilustrasikan pada Cambar 3-5.

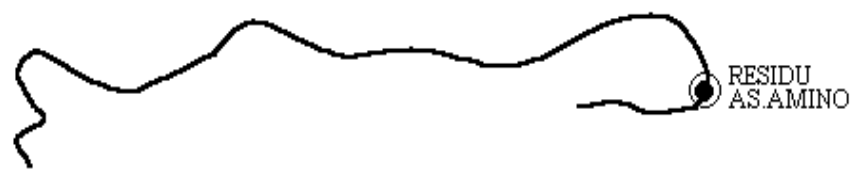

\section{Cambar 3-5: Struktur primer}

Berat molekul, komposisi asam amino, dan posisi residu asam amino dalam polipeptida penyusun protein sangat berperan dalam protein struktur primer. Pengukuran berat molekul dapat dilakukan dengan berbagai metode, antara lain metode osmotic pressure, light scattering, diffusion and viscosity, gel filtration, sedimentasi dengan ultracentrifuge, dan komposisi kimiawi. Setiap metode mempunyai kelebihan dan kekurangannya masingmasing. Pengukuran komposisi asam amino dalam protein antara lain dilakukan dengan cara hidrolisa, kromatografi dan reaksi warna, misalnya reaksi ninhidrin. Hidrolisa dapat dilakukan dengan asam misalnya $\mathrm{HCl}$ pekat $(6 \mathrm{~N})$, basa dan ensim. Posisi residu asam amino dapat ditentukan dengan sequential analysis 
misalnya dengan menggunakan dinitrofluorobenzene. Senyawa tersebut akan berikatan dengan gugus amino dari asam amino membentuk dinitrophenyl (DNP). Selanjutnya N-terminal amino ini akan diidentifikasi dengan cara hidrolisa, demikian juga untuk C-terminal. Sequemtial analysis dapat juga dilakukan dengan hidrolisa ensimatis.

\section{b. STRUKTUR SEKUNDER}

Protein struktur sekunder mempunyai bentuk molekul tiga dimensi dan mempunyai rantai-rantai cabang. Struktur sekunder mempunyai bentuk spiral ( $\alpha$-helix) dan bentuk lipatan ( $\beta$-lembaran). Bentuk $\alpha$ misalnya terdapat pada wool, kolagen, sedang bentuk $\beta$ misalnya terdapat pada benang sutera. Struktur sekunder merupakan bentuk berulang struktur primer, baik sebagai bentuk $\alpha$ maupun bentuk $\beta$. Pada tempat-tempat tertentu yaitu pada struktur primeryang berdekatan akan terbentuk ikatan silang. Contohnya ribonuklease pankreas sapi berupa rantai tunggal yang terdiri dari 124 residu asam amino membentuk ikatan silang di empat tempat melalui jembatan disulfida dengan $\mathrm{N}$-terminal berupa Lys dan C-terminal berupa Val. Protein struktur sekunder diilustrasikan pada Gambar 3-6.

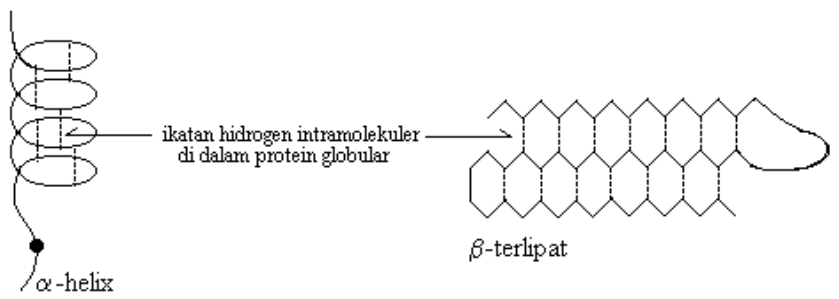

Gambar 3-6: Struktur sekunder 


\section{c. STRUKTUR TERSIER}

Struktur tersier dibentuk oleh adanya interaksi antara rantai cabang dari struktur sekunder dengan residuasamamino. Struktur tersier merupakan gabungan dari berbagai interaksi, antara lain interaksi hidrofobik, ikatan disulfida, ikatan hidrogen, dan ikatan ionik. Interaksi hidrofobik mempunyai kemampuan yang besar untuk menstabilkan struktur tersier dari semua protein, misalnya leusin, valin, fenilalanin, metionin. Ikatan disulfida, hanya terdapat pada beberapa protein saja, misalnya sistein. Ikatan hidrogen antar ujung rantai polar, misalnya asam glutamat, asparagin, glutamin. Ikatan ionik atau ikatan garam, misalnya lisin, arginin, asam aspartat, asam glutamat. Protein struktur tersier diilustrasikan pada Gambar 3-7.

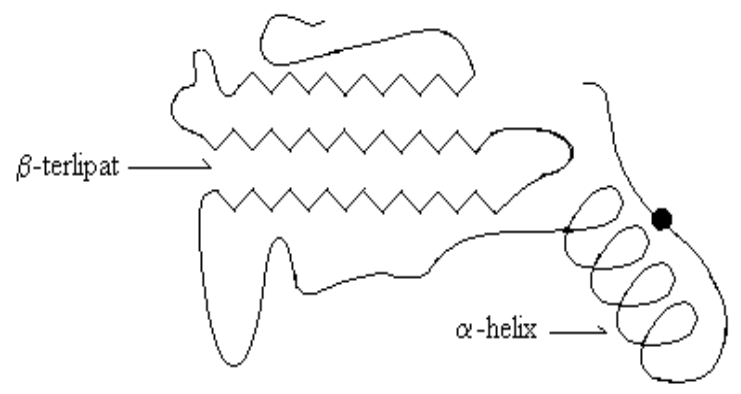

Gambar 3-7: Struktur tersier

\section{d. STRUKTUR KUARTERNER}

Struktur kuarterner disusun oleh dua rantai polipeptida atau lebih yang disatukan oleh gaya nonkovalen (yaitu bukan ikatan peptida atau sulfida). Gaya-gaya yang menstabilkan agregasi ini pada umumnya adalah ikatan hidrogen dan ikatan elektrostatik yang dibentuk antar residu pada permukaan rantai peptida. 
protein hasil agregasi ini disebut oligomer, dan rantai polipeptida penyusunnya disebut protomer atau monomer atau subunit. Protein oligomer yang sering ditemukan mengandung 2 atau 4 monomer, misalnya hemoglobin disusun oleh 4 monomer, yaitu 2 monomer bentuk $\alpha$ dan 2 monomer bentuk $\beta$. Contoh lain ensim glikogen fosforilase yang disusun oleh 4 monomer, apabila keempat monomer itu berdiri sendiri, maka tidak mempunyai aktifitas ensim. Oligomer yang disusun oleh 2 monomer disebut dimer dan yang disusun oleh 4 monomer disebut tetramer. Protein kuarterner atau tetramer diilustrasikan pada Gambar 3-8.

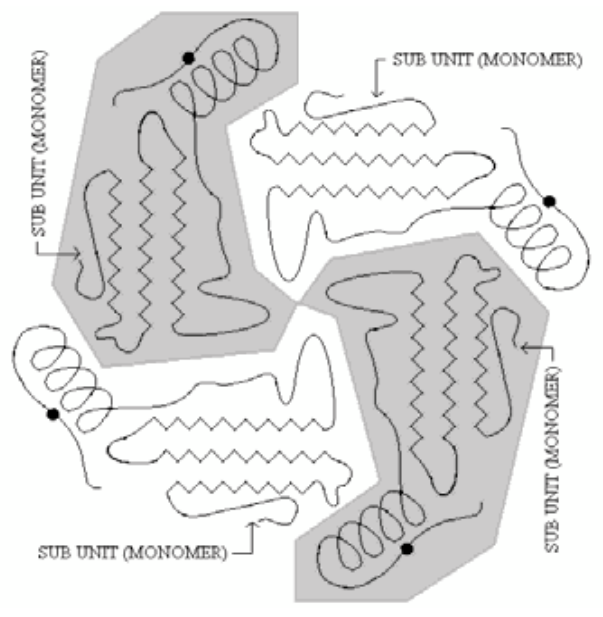

\section{Gambar 3-8: Struktur kuarterner (tetramer)}

Struktur primer merupakan penentu pada struktur yang lebih tinggi. Jadi struktur primer menentukan struktur sekunder (lipatan regional spesifik) dan struktur tersier (interaksi spesifik), serta kuarterner (agregasi spesifik). Penentuan struktur sekunder dan tersier yang sekarang banyak dilakukan adalah dengan 
metode kristalografi sinar-X, metode lainnya misalnya dispersi rotasi optik. Penentuan struktur kuarterner meliputi penentuan jumlah dan jenis monomer serta sifat interaksinya. Metode yang dapat digunakan antara lain ultrasentrifugasi, sentrifugasi gradien densitas sukrosa, filtrasi melalui ayakan molekul, dan Poly Acrylamide Gel Eletrophoresis (PACE).

\subsubsection{IKATAN PADA PROTEIN}

Struktur protein dipertahankan melalui dua ikatan kuat dan lemah. Ikatan kuat yaitu ikatan peptida dan ikatan disulfida, sedangkan ikatan lemah yaitu ikatan hidrogen, ikatan hidrofobik, dan ikatan elektrostatik atau ikatan garam.

\section{a. IKATAN PEPTIDA}

Ikatan peptida dibentuk antara $\alpha$-karboksil dan $\alpha$-nitrogen. Ikatan C-N ini mempunyai ikatan rangkap parsial serta mempunyai sifat seperti bipolar. Atom-atom $\mathrm{C}$ dan $\mathrm{N}$ terletak di dalam bidang yang sama atau koplanar, termasuk juga atom $\mathrm{O}$ dan atom $\mathrm{H}$. Pembentukan ikatan rangkap parsial diilustrasikan pada Gambar 4-9 dan ikatan peptida diilustrasikan pada Cambar 4-10.

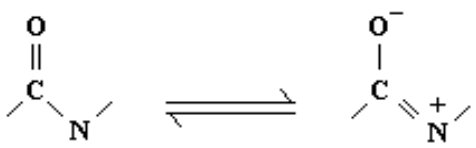

\section{Cambar 3-9: Pembentukan ikatan rangkap parsial}

Bila suatu deret ikatan peptida yang terbentuk dari asam $\alpha$-amino dirangkaikan menjadi satu, kedudukan keruangan rantainya akan bergantung kepada hubungan antara bidang gugus amidanya. 


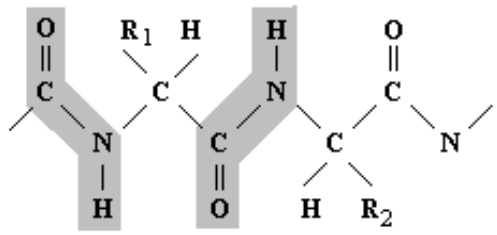

Gambar 3-10: Rantai polipeptida

Empat atom koplanar terdapat pada bidang yang diarsir, keempat atom ini membentuk ikatan peptida. Atom-atom yang tidak berada dalam bidang yang diarsir adalah atom $\mathrm{C}-\alpha$, atom $\mathrm{H}-\alpha$, dan gugus $\mathrm{R}-\alpha$ asam amino tertentu. Jarak antara dua atom $\mathrm{C}-\alpha$ yang berdekatan adalah $0,36 \mathrm{~nm}$.

\section{b. IKATAN DISULFIDA}

Ikatan disulfida terbentuk antara dua residu yang saling berhubungan. Ikatan ini relatif stabil dan resisten terhadap penyebab denaturasi protein. Beberapa senyawa yang mampu memecah ikatan disulfida sistein, antara lain asam performat (oksidator pada ikatan S-S) menghasilkan dua asam sisteik, sedangkan $\beta$-merkaptoetanol (reduktor pada ikatan S-S) menghasilkan dua sistein. Ikatan disulfida dan pemecahannya oleh oksidasi asam performat dan oksidasi $\beta$-merkaptoetanol seperti dibagankan pada Gambar 3-11.

Gambar 3-11:

Pemecahan ikatan

disulfida oleh

oksidasi asam

performat dan

b-merkaptoetanol

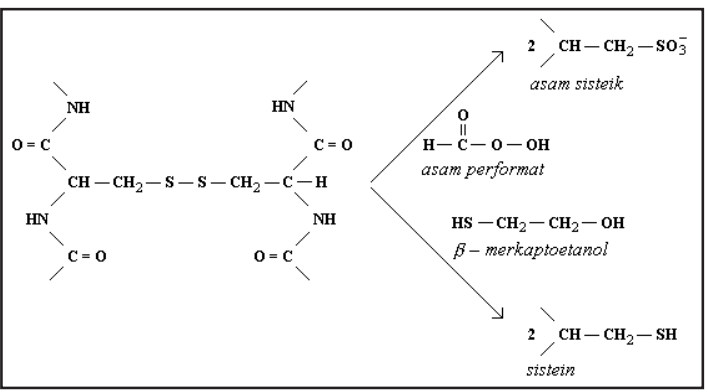




\section{c. IKATAN HIDROGEN}

Ikatan hidrogen terbentuk antara residu pengikat yang terdapat pada rantai samping ikatan peptida asam amino dan ikatan yang terbentuk antara atom hidrogen dengan oksigen ikatan peptida sendiri. Ikatan hidrogen penting untuk mempertahankan struktur primer. Ikatan hidrogen diilustrasikan pada Gambar 3-12.

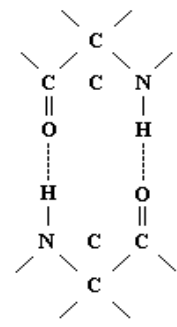

\section{Gambar 3-12: Ikatan hidrogen}

Ikatan hidrogen antara ikatan peptida yang tidak berdekatan menghasilkan pembentukan struktur reguler seperti $\alpha$-helix dan $\beta$-berlipat.

\section{d. IKATAN HIDROFOBIK}

Rantai samping nonpolar dari asam amino netral pada protein cenderung bersekutu. Meskipun persekutuannya tidak stoikiometri tetapi memegang peranan penting dalam mempertahankan struktur protein.

\section{e. IKATAN ELEKTROSTATIK}

Ikatan elektrostatik merupakan ikatan garam antara gugus yang bermuatan berlawanan pada rantai samping asam amino. Contohnya asam amino lisin mempunyai muatan bersih $1+$ 
(positif) dan aspartat atau glutamat mempunyai muatan bersih 1- (negatif), oleh karena itu keduanya saling bereaksi secara elektrostatika untuk menstabilkan struktur protein.

Selama denaturasi protein, ikatan hidrogen, ikatan hidrofobik, dan ikatan elektrostatik pecah, tetapi ikatan peptida dan ikatan disulfida tetap utuh tidak mengalami pemecahan.

\subsection{SIFAT KIMIA PROTEIN}

Beberapa sifat kimia protein yang penting antara lain sifatsifat amfoter, pengikatan ion, hidrasi, reaksi pewarnaan, hidrolisa, oksidasi-reduksi, sifat koloid, dan sifat sensoris.

\subsubsection{AMFOTER}

Sifat amfoter merupakan kemampuan protein untuk dapat bereaksi dengan asam atau basa. Gugus karboksil bebas pada protein sangat lemah, namun demikian dapat bereaksi dengan basa. Gugus amino bebas pada sisi yang lain merupakan akseptor hidrogen dan dapat bereaksi dengan asam. Hanya beberapa molekul protein yang mempunyai gugus-gugus yang dapat bereaksi, diantaranya adalah gugus karboksil pada asam glutamat dan aspartat, serta gugus amino pada lisin.

Gugus-gugus karboksil dan amino pada asam amino terikat melalui iakatan peptida, misalnya glisin. Gugus-gugus amino pada histidin, triptofan, prolin, dan hidroksiprolin bukan merupakan gugus amino dasar, tetapi dapatmengikation hidrogen. Kemampuan protein untuk bertindak sebagai asam atau basa tidak hanya tergantung kepada jumlah gugus-gugusnya, tetapi juga posisinya, demikianjuga apakah permukaan molekulnya terbuka atau tertutup. 


\subsubsection{PENGIKATAN ION}

Melalui reaksi dengan gugus karboksil bebas dan amino bebas, protein dapat mengikat kation dan anion. Pada nilai pH di atas titik isoelektris, protein berada sebagai ion negatif dan karena itu dapat mengikat atau bereaksi dengan kation. Pada $\mathrm{pH}$ di bawah titik isoelektris, protein berada sebagai ion positif dan karena itu dapat mengikat atau bereaksi dengan anion. Pengendapan protein oleh ion logam berat tergantung pada susunan garam protein. Sejumlah ion logam mempunyai kemampuan membentuk senyawa koordinasi (ion kompleks) dan segera bereaksi dengan $\mathrm{N}$-terminal, substitusi amin pada rantai peptida, dan $\mathrm{N}$-imidasol. $\mathrm{Cu}, \mathrm{Ni}$, dan Fe merupakan logam-logam yang mampu membentuk senyawa kompleks dengan protein.

Dalam sebagian besar makanan, protein terdapat sebagai campuran, dan beberapa protein berada di bawah titik isoelektris, dan yang lain berada di atas titik isoelektris. Pada kondisi tertentu, kation akan mengikat beberapa protein dan anion mengikat yang lain.

\subsubsection{HIDRASI PROTEIN}

Protein dapat membentuk hidrat dengan air dan tipe reaksi ini sangat penting karena seringkali dijumpai dalam kimia pangan. Molekul protein mengandung gugus-gugus nitrogen atau atom oksigen yang mengandung pasangan elektron, dan sanggup membentuk ikatan hidrogen. Nitrogen baik dalam rantai peptida maupun dalam gugus amino bebas yang relatif negatif dapat menarik hidrogen pada molekul air. 
Ikatan rangkap oksigen pada gugus karboksil $(-\mathrm{COOH})$ atau karbonil (-CO) dalam rantai peptida lebih negatif dan mempunyai daya tarik terhadap hidrogen lebih besar daripada notrogen. lonisasi gugus yang terbentuk pada $\mathrm{pH}$ di bawah atau di atas titik isoelektris mempunyaiafinitas atau daya gabung terhadapairlebih besar, akibatnya pembentukan hidrat lebih banyak terjadi pada $\mathrm{pH}$ di luar titik isoelektris. Molekul air yang telah terikat tersebut dapat menarik molekul air lainnya membentuk agregat. Agregat air dapat terbentuk di sekitar gugus polar pada molekul protein. Molekul protein yang terdispersi bersama-sama dengan senyawa lain, misalnya senyawa elektrolit, gula, alkohol, dan lain-lain, maka akan terjadi kompetisi pengikatan air untuk membentuk hidrat. Hal ini terjadi karena senyawa elektrolit, gula, alkohol mempunyai kecenderungan mengikat air dan membentuk hidrat. Besarnya hidrasi protein yang terdispersi tidak hanya tergantung pada konsentrasi protein yang terdispersi, tetapi juga tergantung $\mathrm{pH}$, adanya senyawa-senyawa yang mengikat air dan juga suhu.

\subsubsection{REAKSI PEWARNAAN}

Beberapa reagen yang direaksikan dengan protein akan memberikan warna tertentu. Dalam banyak hal reaksi-reaksinya memerlukan adanya gugus-gugus tertentu dalam protein. Sejumlah reaksi dapat digunakan untuk penentuan protein secara kualitatif, beberapa di antaranya sebagai berikut:

\section{1). REAKSI XANTOPROTEIN}

Apabila protein dipanaskan bersama-sama dengan asam nitrat pekat akan menghasilkan endapan putih 
yang segera akan berubah menjadi orange. Reaksi ini disebabkan oleh adanya gugus aromatis. Gugus aromatis antara lain dimiliki oleh fenilalanin, tirosin, triptofan. Jadi reaksi ini dapat digunakan untuk penentuan asam amino yang mengandung gugus aromatis.

\section{2). REAKSI BIURET}

Apabila Cu-sulfat ditambahkan ke dalam larutan protein dalam alkali kuat, maka warnanya akan berubah dari purple (merah ungu) menjadi violet (ungu). Perubahan warna tersebut khas untuk senyawa yang mengandung dua gugus - NH-CO- yang berikatan secara langsung atau terpisah oleh atom $\mathrm{C}$ atau N. Perubahan warna itu disebabkan oleh ikatan peptida, tetapi perubahan warna itu juga dapat disebabkan oleh senyawa bukan peptida yang mempunyai struktur seperi protein, misalnya biuret.

$$
\underset{\mathbf{R}}{-\mathrm{NH}}-\underset{\mathrm{C}}{\mathrm{CO}}-\mathrm{CH}-\mathrm{NH}-\mathrm{CO} \quad \mathrm{NH}_{2}-\mathrm{CO}-\mathrm{NH}-\mathrm{CO}-\mathrm{NH}_{2}
$$

ikatan peptida senyawa biuret

Reaksi ini dapat digunakan untuk analisa kuantitatif berdasarkan pada ikatan peptida.

\section{3). REAKSI NINHIDRIN (TRIKETOHYNDRINDENE)}

Apabila protein, peptone, atau asam amino bebas dipanaskan bersama-sama dengan ninhidrin akan memberikan warna biru. Reagen ini banyak digunakan untuk penentuan asam amino secara kuantitatif atau kualitatif. Apabila protein dipanaskan bersama 
reagen yang mengandung $\beta$-naftoquinon sulfonat, akan memberikan warna merah. Penentuan asam amino secara kuantitatif dapat menggunakan metode spektrofotometri.

\subsubsection{HIDROLISA}

Ikatan peptida dalam protein terhidrolisa oleh asam kuat, alkali, dan ensim tertentu. Apabila protein dipanaskan beberapa jam dalam $\mathrm{HCl} 6 \mathrm{~N}$, maka akan terhidrolisa sempurna menjadi komponen asam-asam aminonya. Apabila protein dididihkan dalam $\mathrm{NaOH} 5 \mathrm{~N}$ juga akan mengalami hidrolisa sempurna. Pemecahan ikatan peptida secara hidrolitik, juga dapat dikatalisis oleh ensim proteolitik.

Setiap ensim proteolitik mempunyai sifat khusus, yaitu akan memecah ikatan peptida tertentu. Endopeptidase akan memecah ikatan peptida yang berada di dalam rantai peptida. Eksopeptidase akan memecah ikatan peptida yang berdekatan dengan gugus $\mathrm{N}$-terminal (disebut amino peptidase) atau yang berdekatan dengan gugus C-terminal (disebut karboksi peptidase). Perlakuan dengan larutan asam pada kondisi tertentu akan mengakibatkan pemecahan ikatan peptida pada asam aspartat, serin, dan treonin. Gugus amida pada glutamin dan asparagin juga mudah terhidrolisa. Hidrolisa parsiil pada protein akan menghasilkan peptida rantai pendek yang mengandung residu-residu asam amino. Pepton diperoleh dari hidrolisa parsiil terhadap protein oleh ensim pencernaan.

Sejumlah peptida sederhana yang dijumpai di alam misalnya glutathione. Glutathione adalah tripeptida yang mengandung asam glutamat, sistein, dan glisin. 


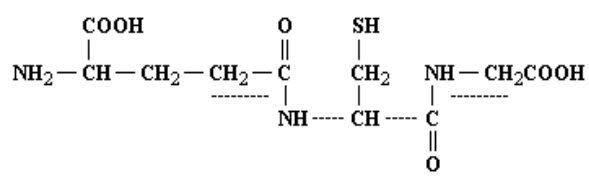

\section{Glutathione}

Berbeda dengan sebagian peptida, dalam glutathione ikatan peptida pada asam glutamat terbentuk pada gugus $\gamma$-karboksil.

\subsubsection{OKSIDASI - REDUKSI}

Molekul protein yang mengandung gugus $\mathrm{SH}$ paling mudah mengalami oksidasi misalnya sistein. Berikut ini merupakan reaksi antara dua gugus sulfhidril.

$$
\mathbf{R}-\mathbf{S H}+\mathbf{H S}-\mathbf{R}^{\prime} \underset{[2 \mathrm{H}]}{\stackrel{[0]}{\rightleftharpoons}} \mathbf{R}-\mathbf{S}-\mathbf{S}-\mathbf{R}^{\prime}
$$

Pada umumnya reaksinya bersifat reversibel dan ikatan disulfida yang terbentuk dapat dipecah oleh reduktor. Ikatan disulfida dibentuk oleh dua gugus sulfhidril dari dua molekul sejenis atau dua molekul yang berbeda. Pembentukan ikatan disulfida ini akan meningkatkan kekakuan atau kekerasan protein. Efek ini tampak jelas pada penggunaan bromat dan oksidator lain pada pemanggangan roti, akan menaikkan daya mekanis dari protein gandum. Apabila ingin mempertahankan atau memecah ikatan silang disulfida, maka ke dalam larutan protein perlu ditambahkan reduktor seperti sistein, merkaptoetanol, glutathione.

\subsubsection{SIFAT KOLOID}

Protein mempunyai berat molekul 10.000 sampai 1.000.000 merupakan partikel koloid. Dalam larutan, molekul 
protein kemungkinan terjadi penggabungan dan membentuk agregat atau misela. Protein globular akan menyerap air dan menggelembung sekali. Bagian yang melakukan penyerapan terhadap air adalah ikatan peptida.

Untuk suspensi yang mengandung fase terdispersi berupa partikel protein berbentuk bola, viskositas sol proteinnya mengikuti persamaan Einstein untuk viskositas, sebagai berikut.

$\begin{aligned} \eta \mathrm{s} & =\eta \mathrm{m}(1+2,50 \phi) \\ \text { dimana: } & \\ \eta s & =\text { viskositas suspensi } \\ \eta m & =\text { viskositas solven (pelarut) } \\ \phi & =\text { volume fraksi komponen terdispersi }\end{aligned}$

Persamaan tersebut dapat digunakan untuk mengestimasi deviasi dari protein yang berbentuk bola atau untuk menentukan tingkat pemecahan protein. Sifat amfoter suatu protein, yaitu muatan elektrostatisyang dimiliki partikel koloiddalamsol protein tergantung pada $\mathrm{pH}$. Dengan demikian untuk mengendapkan protein dari solnya dapat dilakukan dengan pertolongan suatu koloid atau sejumlah besar ion yang bermuatan berlawanan. Efek ini digunakan untuk mendaur ulang protein dari limbah industri. Dasar tersebut digunakan untuk menguji bahan pewarna pada makanan dengan menggunakan wool sebagai bahan pengabsorbsinya.

Larutan protein dan terutama albumin cenderung membentuk busa yang berlimpah. Pembusaan putih telur merupakan sifat paling penting untuk bahan yang digunakan sebagai bahan dasar dalam pembuatan kembang gula dan roti. 
Rantai yang panjang dari protein, sanggup melakukan ikatan hidrogen dan hidrasi. Protein dapat membentuk gel yang stabil asalkan rantainya meluas dan memungkinkan terjadinya pengikatan silang antar rantai. Celatin adalah suatu gel dari protein yang diperoleh apabila kolagen diperlakukan dengan air panas, gelatin banyak digunakan dalam industri makanan.

Molekul protein pada saat yang sama mempunyai gugusgugus baik hidrofobik maupun hidrofilik. Oleh karena itu, protein dapat diharapkan berperan sebagai stabilizer pada emulsi antara air dan lemak, misalnya emulsi pada kuning telur dan susu, dimana butir-butir lemak diselimuti suatu membran yang bagian utamanya berupa lipoprotein.

\subsubsection{SIFAT SENSORIS}

Protein murni tidak berasa, tidak berbau, dan tidak berwarna, kecuali monellin mempunyai rasa yang sangat manis. Rasa, warna atau bau dari protein kemungkinan berasal dari preparasi yang kurang bersih atau berasal dari gugus prostetis. Bahan pangan yang banyak mengandung protein dapat mengalami dekomposisi, membentuk bau busuk. Bau busuk tersebut dikarenakan hasil dekomposisi berupa molekul-molekul berberat molekul rendahyang mengandung N, Satau keduanya. Gugus sulfhidril mudah dilepaskan dari protein membentuk $\mathrm{H}_{2} \mathrm{~S}$ misalnya pada pembusukan telur. Bau adonan terutama dikarenakan terbentuknya $\mathrm{H}_{2} \mathrm{~S}$ dari gluten yang terdapat dalam gandum yang terjadi selama adonan diuli. 


\subsection{DENATURASI}

Secara kimiawi yang dimaksud denaturasi adalah kehilangan aktivitas biologis berupa perubahan sifat fisiko-kimia. Perubahanperubahan tersebut antara lain hilangnya kemampuan melarut, artinya terjadi pengendapan, terbentuknya gel, terbukanya gugus reaktif (sulfhidril), lebih mudah mengalami hidrolisa ensimatis (sehingga daya cernanya lebih baik), perubahan defraksi atau pembiasan sinar $X$ dan putaran optis.

Secara fisika, denaturasi diartikan sebagai suatu perubahan konformasi (bentuk, bangun) rantai polipeptida yang tidak mempengaruhi struktur primernya. Jadi kerusakan yang terjadi adalah pada struktur sekunder, tersier, dan kuarterner, karena ikatan yang bertanggung jawab untuk mempertahankan struktur tersebut sangat lemah, sehingga denaturasi merupakan destruksi ikatan valensi sekunder yang berperan pada konformasi protein. Tetapi hal itu bukan disebabkan oleh pecahnya ikatan kovalen, bukan pula karena proteolitis.

Denaturasi pada protein globular sering kali merusakjala-jala polipeptida karena lipatan-lipatan polipeptidanya akan terbuka sehingga berubah bentuk menjadi polimer random coil. Perubahan tersebut dapat digunakan untuk menerangkan pembentukan gel, koagulasi, naiknya reaktifitas. Kerusakan tersebut diakibatkan oleh adanya perlakuan asam atau basa kuat, panas, detergen ionik (amfitat), garam pekat (urea, guanidin), logam berat ( $\mathrm{Ag}, \mathrm{Pb}$, $\mathrm{Hg}$ ) pelarut-pelarut organik (etil alkohol, fenol). 
Menurut Colvin, denaturasi diartikan suatu order-disorder transition atau perubahan dan pemulihan tatanan. Kenyataannya perubahan ini bersifat irreversible karena proses denaturasi jauh lebih lambat daripada proses renaturasi.

Denaturasi protein merupakan proses awal yang sangat penting pada teknologi makanan. Inaktivasi ensim oleh panas pada umumnya dikarenakan terjadi denaturasi. Denaturasi protein berpengaruh pada teksturdanflavormakanan. Terbukanya gugus SH pada pengolahan makanan berprotein tinggi seperti susu dan telur akan menyebabkan flavoryang spesifik.[] 


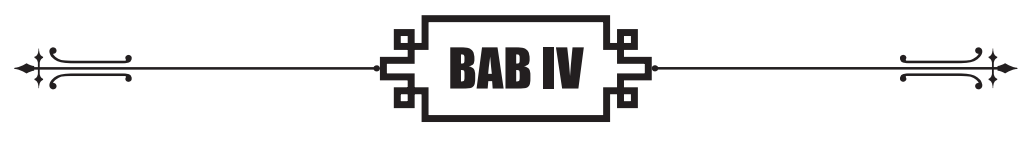

\section{ENZIM DHN KINEEIKR ENZIM}

\subsection{ENZIM}

Enzim adalah biokatalisator, sebagai katalisator organikyang dihasilkan oleh sel. Katalisator adalah zat yang mempercepat reaksi kimia tanpa mengubah struktur zat itu sendiri. Katalisator mengalami perubahan fisik selama reaksi, tetapi segera kembali pada kedudukan asalnya setelah reaksi selesai. Enzim adalah katalisator protein untuk reaksi kimia dalam sistem biologik. Setiap enzim menghasilkan sedikit reaksi, bahkan seringkali hanya satu reaksi, sehingga dengan demikian enzim merupakan katalisator untuk reaksi spesifik. Pada prinsipnya, semua reaksi biokimiawi dikatalisis oleh enzim. Bahan atau substansi yang mengalami perubahan oleh katalisator enzim disebut substrat. Enzim dapat diekstraksi dari dalam sel tanpa kehilangan aktivitas katalitiknya.

\subsubsection{TATA NAMA ENZIM}

Enzim biasanya diberi nama dengan membubuhkan akhiran -ase pada nama dasarnya untuk menunjukkan fungsinya atau membubuhkan nama substrat tempat enzim itu bekerja. 
Pembubuhan akhiran -ase pada nama dasar misalnya oksidoreduktase, yaitu enzim yang mengkatalisis reaksi oksidasireduksi, fosfatase yaitu enzim yang mengkatalisis hidrolisa ester fosfat, transferase yaitu enzim yang bertindak memindahkan suatu gugus tertentu, laktat-dehidrogenase yaitu enzim yang mengkatalisis dehidrogenasi asam laktat.

Pembubuhan akhiran -ase ke nama substrat tempat ensim bekerja misalnya amilasi, yaitu enzim yang menghidrolisis senyawa pati atau amylum, yang lain lipase yaitu enzim yang menghidrolisis lemak atau lipos, demikian juga proteinase yaitu enzim yang menghidrolisis protein.

Ada beberapa perkecualian, misalnya untuk enzim pepsin, tripsin, tidak diakhiri dengan -ase. Seringkali juga dijumpai penamaan enzim tidak diakhiri dengan akhiran-ase tetapi diganti dengan-asa.

Banyak nama-nama enzim tetap dipakai sampai sekarang. Sejalan dengan itu jumlah enzim terus bertambah sehingga kadang-kadang membingungkan tentang enzim mana yang sebenarnya dimaksud. Untuk itu kemudian dilakukan usaha mengembangkan sistem klasifikasi dan tata nama yang secara kimiawi lebih rasional. Cara baru ini adalah Sistem Tata Nama IUB (Internationak Union of Biochemistry) yang mulai dikembangkan sejak tahun 1972 dan secara periodik diperbarui.

\subsubsection{STRUKTUR ENZIM}

Kebanyakan enzim merupakan protein terkonyugasi, terdiri dari bagian protein dan bagian bukan protein. Bagian bukan protein ini terikat kurang kuat dengan bagian protein, sehingga dapat dipisahkan dengan dialisa. Bagian protein disebut 
apoenzim sedangkan bagian bukan protein disebut koenzim (=gugus prostetis), sistem apoenzim-koenzim ini disebut holoenzim. Koenzim merupakan gugus fungsi yang juga disebut kofaktor, berupa molekul-molekul kecil dan umumnya berupa ion logam atau molekul organik. Koenzim yang berikatan secara kovalen dengan apoenzim disebut gugus prostetik. Koenzim kecuali berikatan secara kovalen dengan apoenzim juga dapat berikatan secara nonkovalen. Beberapa koenzim seperti disajikan dalam Tabel 4-1. Enzim yang memerlukan koenzim logam disebut metaloenzim.

Tabel 4-1.: Beberapa koenzim logam dan senyawa organik

\begin{tabular}{|c|l|l|l|}
\hline No. & \multicolumn{1}{|c|}{ Kode } & \multicolumn{1}{|c|}{ Nama kepanjangan } & Memindah \\
\hline \multicolumn{2}{|c|}{ Koenzim logam: } & \\
\hline 1. & $\mathrm{Zn}^{++}$ & lon Zink & \\
\hline 2. & $\mathrm{Mg}^{++}$ & lon Magnesium & \\
\hline 3. & $\mathrm{Fe}^{++}$ & lon Fero & \\
\hline 4. & $\mathrm{Fe}^{+++}$ & lon feri & \\
\hline 5. & $\mathrm{Cu}^{++}$ & lon Cupri & \\
\hline 6. & $\mathrm{Cu}^{+}$ & lon Cupro & \\
\hline 7. & $\mathrm{~K}^{+}$ & lon Kalium & \\
\hline 8. & $\mathrm{Na}^{+}$ & Ion Natrium & \\
\hline
\end{tabular}

Tabel 4-1.: Beberapa koenzim logam dan senyawa organik (lanjutan)

\begin{tabular}{|c|c|c|c|}
\hline No. & Kode & Nama kepanjangan & Memindah \\
\hline \multicolumn{4}{|c|}{ Koenzim senyawa organik: } \\
\hline 1. & $\mathrm{NAD}^{+}$ & Nikotinamida Adenin Dinukleotida & hidrogen \\
\hline 2. & NADP & Nikotinamida Adenin Dinukleotida Phosphate & hidrogen \\
\hline 3. & FMN & Flavin Mono Nukleotida & hidrogen \\
\hline 4. & FAD & Flavin Adenin Dinukleotida & hidrogen \\
\hline 5. & KoQ & Koenzim-Q atau Quinon & hidrogen \\
\hline 6. & Sit & Sitokrom & elektron \\
\hline 7. & $\mathrm{Fd}$ & Ferrodoksin & elektron \\
\hline
\end{tabular}




\begin{tabular}{|c|l|l|l|}
\hline 8. & ATP & Adenosin Tri Phosphate & gugus fosfat \\
\hline 9. & PAPS & Phospho Adenil Sulfat & gugus sulfat \\
\hline 10. & UDP & Uridina Di Phosphate & gula \\
\hline 11. & Biotin & Biotin & karbonil \\
\hline 12. & KoA & Koenzim-A & asetil \\
\hline 13. & TPP & Tiamin Piro Phosphate & C2-aldehida \\
\hline
\end{tabular}

Dari tabel di atas tampak bahwa koenzim dapat berperan sebagai pemindah $\mathrm{H}$ dan pemindah gugus lain selain $\mathrm{H}$. Koenzim pemindah $\mathrm{H}$ antara lain $\mathrm{NAD}^{+}$, NADP, FMN, FAD, Asam lipoat, Koenzim-Q. Koenzim pemindah gugus selain $H$ antara lain Fosfat gula, KoA-SH, TPP, Piridoksal fosfat, Koenzim folat, Biotin, Koenzim kobamida $\left(B_{12}\right)$, Asam lipoat.

Banyak vitamin dalam bahan makanan merupakan koenzim. Koenzim oksidoreduktase yang paling penting ialah $\mathrm{NAD}^{+}$yang dapat menerima hidrida untuk menjadi NADH. Koenzim $\mathrm{NAD}^{+}$merupakan zat pengoksida, karena koenzim ini mendehidrogenasikan suatu substrat. Sumber NAD ${ }^{+}$adalah vitamin niasin. Vitamin $B_{2}$ atau riboflavin merupakan calon FAD yaitu suatu koenzim oksidoreduktase juga. Vitamin $B_{1}$ atau tiamin berperan dalam dekarboksilasi asam $\alpha$-keto, sedang vitamin $B_{6}$ atau piridoksal berperan dalam transaminasi sintesa asam amino. Sebagai ilustrasi peranan koenzim NAD dalam reaksi oksidoreduksi sebagai berikut.

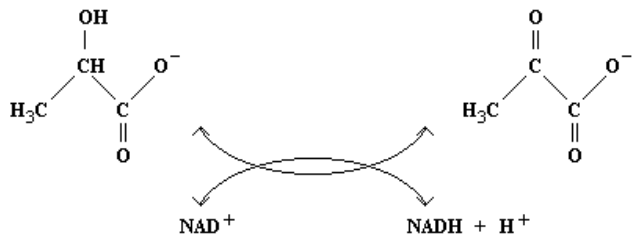

Gambar 4-1: Peranan NAD dalam reaksi oksidoreduksi 


\subsubsection{KLASIFIKASI ENZIM}

Menurut Commission of Enzymes of the International Union of Biochemsitry, enzim diklasifikasikan menjadi enam kelas berdasarkan kepada tipe reaksinya. Keenam kelas tersebut yaitu oksidoreduktase, transferase, hidrolase, liase, isomerase, ligase atau sintetase.

\section{a. OKSIDOREDUKTASE}

Oksidoreduktase yaitu enzim yang mengkatalisis oksidoreduksi antara dua substrat, pada gugus-gugus $\mathrm{C}=\mathrm{CH}$-, $\mathrm{CH}-\mathrm{CH}, \mathrm{C}=\mathrm{O}, \mathrm{CH}-\mathrm{NH}-$, NADH, NADPH, $\mathrm{CH}-\mathrm{OH}$ (sebagai donor elektron), $\mathrm{CH}-\mathrm{NH}_{2}$ (sebagai donor elektron), $\mathrm{H}_{2} \mathrm{O}_{2}$ (sebagai akseptor elektron). Termasuk oksidoreduktase contohnya dehidrogenase, reduktase, oksidase, oksigenase, hidroksilase, katalase. Beberapa di antaranya disajikan pada Tabel 4-2 berikut ini.

\section{Tabel 4-2. : Enzim oksidoreduktase}

\begin{tabular}{|c|l|l|l|}
\hline No. & \multicolumn{1}{|c|}{ Substrat } & \multicolumn{1}{c|}{ Enzim } & \multicolumn{1}{c|}{ Hasil } \\
\hline 1. & $\mathrm{CH}-\mathrm{OH}$ (alkohol) & $\begin{array}{l}\text { NAD oksidoreduktase } \\
\text { (alkohol dehidrogenase) }\end{array}$ & $\begin{array}{l}\text { aldehid atau keton + } \\
\mathrm{NADH}+\mathrm{H}^{+}\end{array}$ \\
\hline 2. & $\begin{array}{l}\mathrm{CH}-\mathrm{NH}_{2} \\
\text { (glutamat) }\end{array}$ & $\begin{array}{l}\mathrm{NAD}(\mathrm{P}) \text { oksidoreduktase } \\
\text { (glutamat dehidrogenase) }\end{array}$ & $\begin{array}{l}\alpha \text {-ketoglutarat }+\mathrm{NH}_{4}^{+} \\
+\mathrm{NAD}(\mathrm{P}) \mathrm{H}+\mathrm{H}^{+}\end{array}$ \\
\hline 3. & $\mathrm{H}_{2} \mathrm{O}_{2}$ & $\begin{array}{l}\mathrm{H}_{2} \mathrm{O} \text {-oksidoreduktase } \\
\text { (katalase) }\end{array}$ & $\mathrm{O}_{2}+2 \mathrm{H}_{2} \mathrm{O}$ \\
\hline
\end{tabular}

\section{b. TRANSFERASE}

Transferase yaitu suatu enzim yang mengkatalisa pemindahan bermacam-macam gugus fungsional, misalnya metil, asetil, aldehid, keton, amin, fosfat, sulfur, asil, alkil, glikosil, 
dari suatu substansi ke substansi lainnya. Beberapa di antaranya disajikan dalam Tabel 4-3 berikut ini.

\section{Tabel 4-3. : Enzim transferase}

\begin{tabular}{|c|l|l|l|}
\hline No. & \multicolumn{1}{|c|}{ Substrat } & \multicolumn{1}{|c|}{ Enzim } & \multicolumn{1}{c|}{ Hasil } \\
\hline 1. & kolin & Asetil Ko-A & KoA + O-asetilkolin \\
\hline 2. & D-heksosa & ATP & ADP + D-heksosa-6P \\
\hline
\end{tabular}

\section{c. HIDROLASE}

Hidrolase adalah enzim yang mengkatalisis pemecahan ikatan secara hidrolisa. Nama trivial enzim adalah dengan cara menambahkan akhiran -ase / -asa pada substratnya, misalnya lipase, proteinase, pektinase, amilase, maltase, dan sebagainya. Enzim ini mengkatalisis hidrolisis ikatan ester, eter, peptida, glikosil, anhidrida asam, C-C, C-halida, atau P-N. Beberapa diantaranya disajikan dalam Tabel 4-4 berikut ini.

\section{Tabel 4-4. : Enzim hidrolase}

\begin{tabular}{|c|l|l|l|}
\hline No. & \multicolumn{1}{|c|}{ Substrat } & \multicolumn{1}{c|}{ Enzim } & \multicolumn{1}{c|}{ Hasil } \\
\hline 1. & $\begin{array}{l}\text { asilkolin } \\
\text { (ester) }\end{array}$ & $\begin{array}{l}\text { Asilkolin asil-hidrolase } \\
\text { (pseudokolinesterase) }\end{array}$ & kolin + asam \\
\hline 2. & $\begin{array}{l}\text { galatosida } \\
\text { (glikosil) }\end{array}$ & $\begin{array}{l}\beta \text {-D-Galaktosida } \\
\text { galaktohidrolase } \\
(\beta \text {-galatosidase) }\end{array}$ & $\begin{array}{l}\text { alkohol + } \\
\text { D-galaktosa }\end{array}$ \\
\hline
\end{tabular}

\section{d. LIASE}

Liase adalah enzim yang mengkatalisa pemecahan ikatan selain melalui hidrolisa. Enzim ini akan melepaskan gugus tertentu dari substratnya kemudian menempelkan gugus tersebut pada ikatan rangkap. Jadi, enzim ini mengadisi pada 
ikatan rangkap misalnya karboksilase (dekarboksilase), aldolase, hidratase. Enzim ini bekerja pada ikatan $\mathrm{C}=\mathrm{C}, \mathrm{C}=\mathrm{O}, \mathrm{C}=\mathrm{N}-, \mathrm{C}-\mathrm{S}$, dan C-halida. Beberapa di antaranya adalah seperti dalam Tabel 4-5 berikut ini.

Tabel 4-5. : Enzim liase

\begin{tabular}{|c|c|l|l|}
\hline No. & \multicolumn{1}{|c|}{ Substrat } & \multicolumn{1}{|c|}{ Enzim } & \multicolumn{1}{c|}{ Hasil } \\
\hline 1. & Ketosa-1P & $\begin{array}{l}\text { Aldehida-liase } \\
\text { (aldose) }\end{array}$ & $\begin{array}{l}\text { dihidroksiasetonfosfat }+ \\
\text { aldehida }\end{array}$ \\
\hline 2. & L-Malat & $\begin{array}{l}\text { L-Malat hidroliase } \\
\text { (fumarase) }\end{array}$ & fumarat $+\mathrm{H}_{2} \mathrm{O}$ \\
\hline
\end{tabular}

\section{e. ISOMERASE}

Isomerase adalah enzim yang mengkatalisa perubahan dari satu bentuk isomer ke bentuk isomer lainnya atau enzim yang mengkatalisa reaksi isomerisasi, misalnya rasemase dan epimerase.

Enzim ini mengkatalisis interkonversi isomer-isomer optik, geometrik atau posisi. Beberapa di antaranya seperti Tabel 4-6 berikut ini.

\section{Tabel 4-6. : Enzim isomerase}

\begin{tabular}{|c|c|c|c|}
\hline No. & Substrat & \multicolumn{1}{|c|}{ Enzim } & \multicolumn{1}{c|}{ Hasil } \\
\hline 1. & $\begin{array}{l}\text { D-gliseral- } \\
\text { dehida-3P }\end{array}$ & $\begin{array}{l}\text { D-gliseraldehid 3-fosfat } \\
\text { ketoisomerase } \\
\text { (triosafosfat isomerase) }\end{array}$ & dihidroksi aseton fosfat \\
\hline
\end{tabular}

\section{f. LIGASEATAU SINTETASE}

Ligase berasal dari kata ligare artinya mengikat. Ligase adalah enzim yang mengkatalisa penggabungan dua molekul, 
enzim ini mengkatalisa tipe sintesa tertentu. Penggabungan dua senyawa ini diikuti oleh pemecahan ikatan pirofosfat dalam ATP atau senyawa yang sejenis. Termasuk golongan ini ialah enzim yang mengkatalisis reaksi pembentukan ikatan C-O, C-S, C-N, dan C-C. Beberapa diantaranya seperti disajikan dalam Tabel 4-7 berikut ini.

Tabel 4-7. : Enzim ligase atau sintetase

\begin{tabular}{|c|l|l|l|}
\hline No. & \multicolumn{1}{|c|}{ Substrat } & \multicolumn{1}{c|}{ Enzim } & \multicolumn{1}{c|}{ Hasil } \\
\hline 1. & $\begin{array}{l}\text { L-Clutamat } \\
+\mathrm{NH}_{4}^{+} \\
+\mathrm{ATP}^{+}\end{array}$ & $\begin{array}{l}\text { L-Glutamat amino ligase } \\
\text { (ADP) (glutamin sintetase) }\end{array}$ & $\begin{array}{l}\text { ADP + ortofosfat+ } \\
\text { L-Glutamin } \\
\text { ikatan C-N }\end{array}$ \\
\hline 2. & $\begin{array}{l}\text { Asetil-KoA } \\
+\mathrm{CO}_{2} \\
+\mathrm{ATP}\end{array}$ & $\begin{array}{l}\text { Asetil-KoA CO ligase (ADP) } \\
\text { (asetil KoA karboksilase) }\end{array}$ & $\begin{array}{l}\text { Malonil-AkoA + ADP + P } \\
\text { ikatan C-C }\end{array}$ \\
\hline
\end{tabular}

Berdasarkan tempat aktivitas enzim dan ditinjau dari sel yang membentuk, maka enzim dapat digolongkan menjadi eksoenzim dan endoenzim. Eksoenzim adalah enzim yang tempat aktivitasnya berada di luar sel, maka juga disebut enzim ekstraseluler. Enzim ini penting dalam pencernaan. Endoenzim adalah enzim yang aktivitasnya berada di dalam sel, ia juga dinamakan enzim intraseluler. Enzim ini penting dalam proses bioenergi dan biosintesa.

\subsection{KINETIKA ENZIM}

Berikut ini akan dibahas tentang faktor-faktor yang mempengaruhi kecepatan reaksi enzimatis. Faktor-faktor tersebut antara lain energi aktivasi, suhu, pH, konsentrasi enzim, konsentrasi substrat, dan kandungan air. 


\subsubsection{KECEPATAN REAKSI}

Persamaan reaksi:

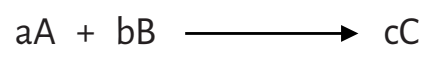

Pada suhu dan tekanan konstan, maka kecepatan reaksi (pembentukan C), sebanding dengan konsentrasi A dan B.

$v=K a b$

Keterangan:

$$
\begin{aligned}
v & =\text { kecepatan reaksi } \\
a & =\text { konsentrasi } A \\
b & =\text { konsentrasi } B \\
K & =\text { konstanta kecepatan reaksi, }
\end{aligned}
$$

besarnya tergantung pada "order reaksi"

Salah satu faktor terpenting yang mempengaruhi $\mathrm{K}$ adalah suhu. Hubungan antara $\mathrm{K}$ dan suhu seperti persamaan dari Arrhenius berikut ini.

$$
\mathrm{K}=\mathrm{Ae}-\frac{\mathrm{E}}{\mathrm{RT}}
$$

Keterangan:

$$
\begin{aligned}
& A=\text { konstanta } \\
& E=\text { energiaktivasi } \\
& R=\text { konstantagas } \\
& T=\text { suhuabsolut }
\end{aligned}
$$

\subsubsection{ENERGI AKTIVASI}

Suatu reaksi molekul A menjadi molekul B, akan terjadi bila molekul A mempunyai cukup energi untuk mencapai keadaan 
teraktivasi atau keadaan transisi. Saat mencapai keadaan transisi ini molekul memerlukan energi aktivasi paling tinggi.

$$
v=K a b
$$

Dari persamaan tersebut dapat diartikan bahwa makin besar nilai K, maka akan menghasilkan kecepatan reaksi ( $v$ ) makin besar.

$$
\mathrm{K}=\mathrm{Ae}-\frac{\mathrm{E}}{\mathrm{RT}}
$$

Dari persamaan tersebut dapat dimengerti bahwa untuk memperoleh nilai Kyang besar diperlukan energi aktivasi $(E)$ yang kecil. Makin kecil nilai (E) berarti nilai (e) makin besar. Sebagai dilustrasi disajikan data hitungan sebagai berikut.

$$
\begin{aligned}
& \operatorname{untuk} E=1, \text { maka } e^{-E}=0,368 \\
& \operatorname{untuk} E=2, \text { maka } e^{-E}=0,135 \\
& \operatorname{untuk} E=3, \text { maka } e^{-E}=0,050 \\
& \operatorname{untuk} E=4 \text {, maka } e^{-E}=0,018 \\
& \operatorname{untuk} E=5, \text { maka } e^{-E}=0,007
\end{aligned}
$$

Seperti telah dijelaskan sebelumnya bahwa enzim merupakan katalisator organik, sama juga dengan katalisator pada umumnya, yaitu berfungsi untuk mempercepat reaksi kimia dengan jalan menurunkan energi aktivasinya. Untuk ilustrasi pencapaian keadaan transisi dua keadaan yang berbeda, yaitu reaksi yang dikatalisa enzim dan reaksi tanpa katalisa enzim disajikan pada Gambar 4-2. 


\section{Gambar 4-2: Kurva energi untuk reaksi enzimatis}

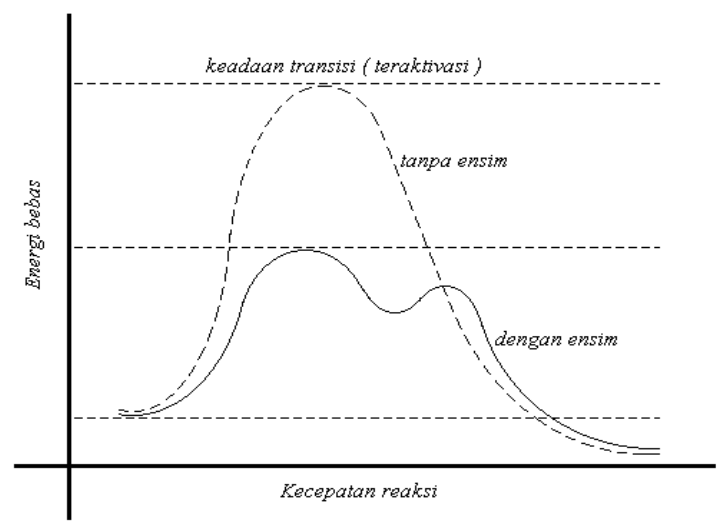

Enzim yang ada akan tergabung sementara dengan substrat membentuk Enzim-Substrat kompleks, sehingga akan mencapai keadaan transisi dengan energi aktivasi lebih rendah dibandingkan dengan reaksi tanpa katalisator enzim.

Energi aktivasi dari beberapa reaksi dengan enzim atau tanpa enzim, seperti tertera dalam Tabel 4-8.

Tabel 4-8: Energi aktivasi beberapa reaksi

\begin{tabular}{|c|l|l|r|r|}
\hline \multirow{2}{*}{ No. } & \multirow{2}{*}{ Reaksi } & Enzim & \multicolumn{2}{|c|}{ Energi aktivasi } \\
\cline { 3 - 5 } & & Tanpa Enzim & Dengan Enzim \\
\hline 1. & Pemecahan $\mathrm{H}_{2} \mathrm{O}_{2}$ & Katalase & 18.000 & 5.000 \\
\hline 2. & Hidrolisa sukrosa & Fruktosidase & 26.000 & 11.000 \\
\hline 3. & Hidrolisa koenzim & Tripsin & 20.000 & 12.000 \\
\hline 4. & Hidrolisa lipida & Lipase & 13.200 & 4.200 \\
\hline
\end{tabular}

Sumber: Z.Berk, 1976, The Biochemistry of Foods, hal.44. 


\subsubsection{PENGARUHSUHU}

Dari persamaan Arrhenius tampak bahwa nilai $K$ dipengaruhi oleh suhu, sedangkan nilai $v$ berbanding langsung dengan $K$, sehingga $v$ dipengaruhi oleh suhu. Suhu optimal untuk kebanyakan enzim berkisar antara $30-40^{\circ} \mathrm{C}$. Adanya kenaikan suhu umumnya kecepatan reaksi akan naik. Setiap kenaikan $10^{\circ} \mathrm{C}$ maka kecepatan reaksi akan naik $2 x$ atau 3x. Tetapi pada daerah suhu tertentu justru berakibat sebaliknya, yaitu akan berakibat terjadi denaturasi enzim. Dari kenyataan itu, maka pengaruh suhu terhadap aktivitas enzim diilustrasikan pada Gambar 4-3.

\section{Gambar 4-3: Kurva pengaruh suhu terhadap aktivasi}

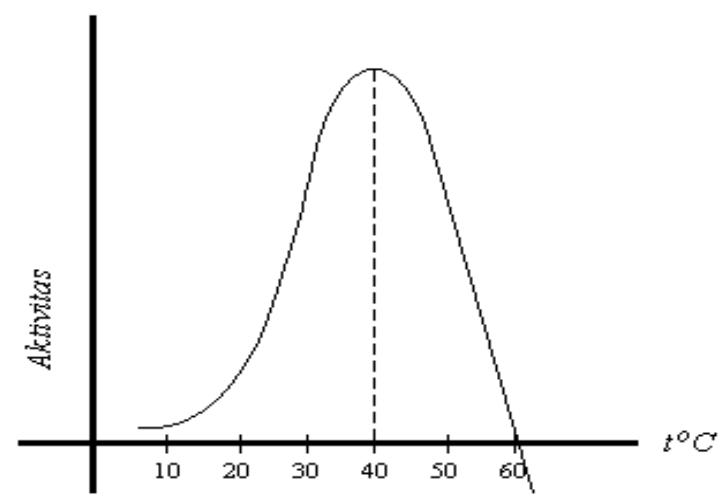

Sumber: Z.Berk, 1976, The Biochemistry of Foods, hal.46

Untuk kebanyakan enzim mempunyai suhu inaktivasi dekat dengan suhu optimumnya. Pada suhu $70-80^{\circ} \mathrm{C}$ umumnya akan terjadi inaktivasi enzim sangat cepat. Tetapi pada suhu rendah masih terjadi aktivitas enzim meskipun kecepatannya sangat 
lambat. Dari kenyataan inilah maka hasil industri makanan beku yang disimpan terlalu lama akan mengalami penurunan mutu karena terjadi kerusakan enzimatis. Suhu optimum untuk setiap enzim ini tidak konstan, masih ditentukan pula oleh waktu inkubasi, semakin lama waktu inkubasi maka suhu optimumnya makin rendah.

\subsubsection{PENGARUHPH}

Setiap reaksi renzimatis mempunyai $\mathrm{pH}$ optimum, ini tergantung pada substrat dan kondisi reaksi, misalnya waktu inkubasi, suhu, konsentrasi substrat, konsentrasi ion, dan sebagainya. Efek pH terhadap kecepatan reaksi enzimatis ini sangat kompleks melalui beberapa tahap reaksi.

Tahap pertama, adanya kandungan gugus yang mudah terionisasi, misalnya gugus: $-\mathrm{COOH}$ bebas, $-\mathrm{NH}_{2}$ bebas, $-\mathrm{SH},-\mathrm{OH}$, besarnya ionisasi dan reaktivitas gugus tersebut tergantung pada $\mathrm{pH}$.

Tahap kedua, $\mathrm{pH}$ akan mempengaruhi struktur dan reaktivitas "Enzim-Substrat kompleks" inhibitor atau aktivator yang ada dan seterusnya. Pada $\mathrm{pH}$ yang sangat tinggi atau sangat rendah berada jauh di bawah atau di atas $\mathrm{pH}$ optimum akan kehilangan aktivitasnya.

Sebagai ilustrasi pengaruh suhu terhadap aktivitas enzim disajikan dalam Gambar 4-4. 
Gambar 4-4: Kurva pengaruh pH terhadap aktivitas enzim

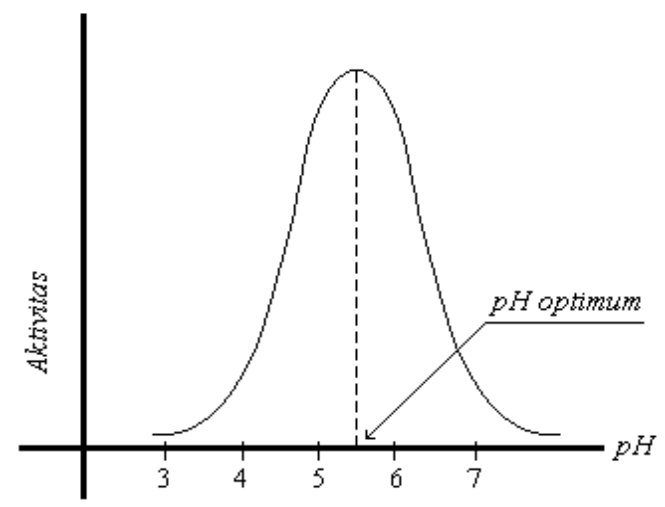

(Sumber:Z.Berk, 1976, The Biochemistry of Foods, hal.47)

\subsubsection{KONSENTRASI ENZIM}

Faktor lain yang mempengaruhi reaksi enzimatis adalah konsentrasi enzim, kecepatan reaksi berbandinglangsung dengan konsentrasi enzim, seperti diilustrasikan pada Cambar 4-5.

Gambar 5-5: Grafik hubungan kecepatan reaksi dan konsentrasi

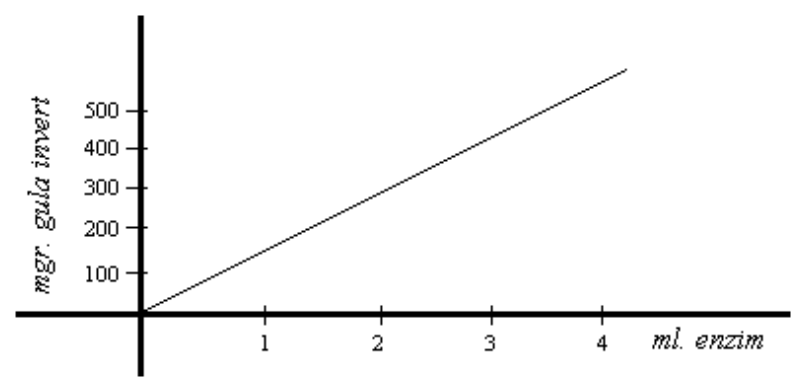

(Sumber: Z.Berk, 1976, The Biochemistry of Foods, hal.48) 


\subsubsection{KONSENTRASISUBSTRAT}

Kecepaan reaksi akan meningkat sejalan dengan naiknya konsentrasi sampai pada tingkat tertentu, setelah itu perubahan kecepatan reaksi sangat kecil (kuvranya hampir datar) akhirnya kecepatannya menjadi konstan. Pengaruh konsentrasi substrat terhadap reaksi enzimatis diilustrasikan pada Gambar 4-6.

Gambar 4-6: Grafik hidrolisa sukrosa oleh invertase pada berbagai konsentrasi substrat

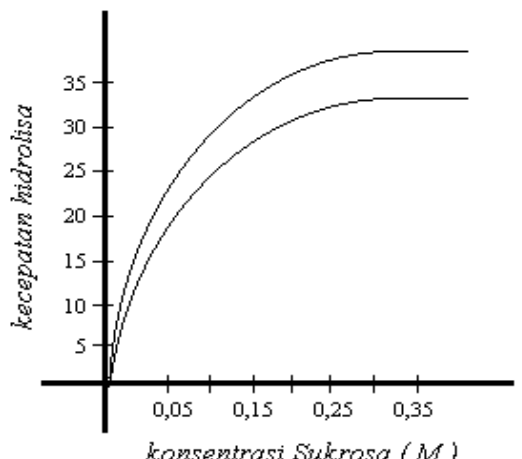

konsentrasi Sukrosa (M)

(Sumber: Z.Berk, 1976, The Biochemistry of Foods, hal.49)

\subsubsection{PENGARUH KANDUNGAN AIR}

Aktivitas enzim akan naik apabila kandungan air bebas naik, (hal ini terjadi pada reaksi-reaksi hidrolitik maupun nonhidrolitik). Peranan air pada reaktan adalah sebagai aktivator penggabungan enzim dan substrat melalui hidrasi atau berperan sebagai medium pembawa atau medium transport.[] 



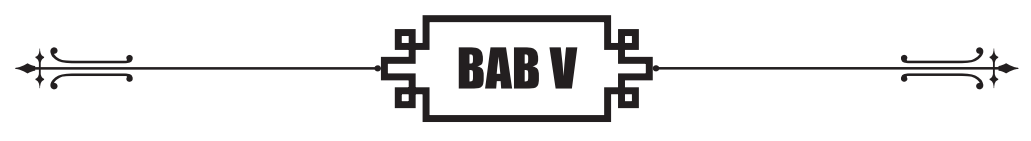

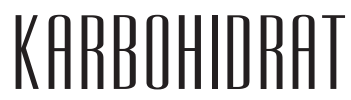

Karbohidrat atau hidrat karbon secara empiris dapat dirumuskan sebagai $\mathrm{C}_{n}\left(\mathrm{H}_{2} \mathrm{O}\right)_{n}$, nilai $n$ berkisar tiga sampai beberapa ratus. Karbohidrat merupakan senyawa organik yang banyak terdapat dalam semua hasil pertanian, dihasilkan dari fotosintesa $\mathrm{CO}_{2}$ dan $\mathrm{H}_{2} \mathrm{O}$. Pada binatang, kebanyakan senyawa organik yang dijumpai berupa derivat karbohidrat, reaksinya dengan amonia akan menghasilkan asam-asam amino, selanjutnya disintesa menjadi molekul protein. Karbohidrat yang tersimpan dalam tumbuh-tumbuhan atau hewan dalam kondisi tertentu dapat diubah menjadi senyawa lain dan teroksidasi hingga menghasilkan tenaga atau energi.

Karbohidrat pada tumbuh-tumbuhan misalnya glukosa, pati, hemiselulosa, gum, glukosida, dan sebagainya. Karbohidrat pada binatang misalnya D-glukosa di dalam darah, laktosa dalam air susu, glikogen, D-ribosa di dalam asam nukleat.

Secara kimia, karbohidrat dapat didefinisikan sebagai suatu senyawa polihidroksialifatis yang juga mengandung gugus-gugus karbonil $(\mathrm{COH})$ atau karboksil $(\mathrm{COOH})$ dan turunan-turunannya. 
Berdasarkan pada jumlah gula yang dihasilkan apabila karbohidrat dihidrolisa, maka secara umum karbohidrat diklasifikasikan menjadi dua golongan besar, yaitu gula sederhana dan gula majemuk. Gula sederhana disebut juga monosakarida. Cula majemuk masih dibedakan menjadi dua, yaitu oligosakarida dan polisakarida. Secara umum, maka karbohidrat dapat diklasifikasikan sebagai berikut.

\section{Cula sederhana (monosakarida)}

Monosakarida terdiri dari pentosa dan heksosa. Pentosa meliputi arabinosa, silosa, ribosa. Heksosa dibedakan menjadi dua, yaitu aldoheksosa (galaktosa, glukosa) dan ketoheksosa (fruktosa).

\section{Gula majemuk (Oligosakarida dan Polisakarida).}

\section{Oligosakarida}

Oligosakarida terdiri dari disakarida dan trisakarida. Disakarida terdiri dari gula reduksi (maltosa, laktosa) dan nonreduksi (sukrosa). Trisakarida berupa gula nonreduksi (rafinosa, gentianosa).

\section{Polisakarida}

Polisakarida terdiri dari homopolisakarida, heteropolisakarida, dan polisakarida majemuk. Homopolisakarida disusun oleh satu jenis unit monosakarida, meliputi pentosan dan heksosan. Pentosan contohnya xilan dan araban. Heksosan dikelompokkan menjadi 
empat, yaitu glukosan (pati, dekstrin, selulosa), fruktosan (inulin), manan, galaktan. Heteropolisakarida disusun oleh dua jenis unit monosakarida atau lebih, misalnya pektin, gum, musilage. Polisakarida majemuk yang mengandung $\mathrm{N}$ contohnya khitin.

\subsection{MONOSAKARIDA}

Monosakarida adalah karbohidrat yang tidak dapat dihidrolisa menjadi senyawa-senyawa yang lebih sederhana. Monosakarida atau gula sederhana bersifat netral, dapat mengkristal, dapat mendefusi, mudah larut dalam air, sedikit larut dalam alkohol dan tidak larut dalam ester.

Berdasarkan letak gugus karbonil dalam molekul, monosakarida dibedakan menjadi aldosa (polihidroksi aldehid) dan ketosa (polihidroksi keton).

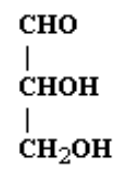

gliseraldehid

(aldosa)

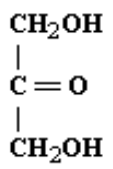

dihidroksi aseton

(ketosa)

\section{Gambar 5-1: Struktur monosakarida}

Berdasarkan pada jumlah atom karbon dalam molekul, monosakarida dikelompokkan menjadi biosa $\left(\mathrm{C}_{2}\right)$, triosa $\left(\mathrm{C}_{3}\right)$, treosa $\left(C_{4}\right)$, pentosa $\left(C_{5}\right)$, heksosa $\left(C_{6}\right)$, heptosa $\left(C_{7}\right)$ dan seterusnya. Dalam monosakarida yang penting adalah heksosa dan pentosa. 


\subsubsection{STRUKTUR MONOSAKARIDA}

Monosakarida dianggap merupakan turunan dari gliseraldehid, yang mana gugus karbonil (aldehid) disubstitusi dengan gugus lain.

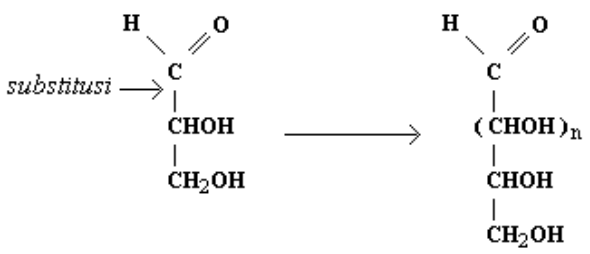

gliseraldehid

gula

\section{Cambar 5-2: Substitusi gliseraldehid}

Pada gliseraldehid tampak bahwa pada C-sentral merupakan C-asimetris karena mengikat empat gugus yang berlainan, yaitu gugus-gugus $-\mathrm{H},-\mathrm{OH},-\mathrm{CH}_{2} \mathrm{OH},-\mathrm{CHO}$, sehingga gliseraldehid mempunyai $n=1$ ( $n$ adalah banyaknya C-asimetris), jadi, gliseraladeih mempunyai $2^{n}=2^{1}=2$

stereoisomer. Untuk membedakan kedua isomer tersebut maka pada gugus $-\mathrm{OH}$ yang berada di sebelah kanan atom C-sentral diberi notasi D (Dextro = kanan) dan gugus $-\mathrm{OH}$ yang berada di sebelah kiri atom C-sentral diberi notasi L (Levo $=$ kiri).<smiles>O=CC(O)CO</smiles>

D-Gliseraldehid<smiles>O=CC(O)CO</smiles>

L-Gliseraldehid

\section{Gambar 5-3: Notasi D dan L}


Notasi D dan L bukan untuk menunjukkan arah putaran bidang terpolarisasi (rotasi optis). Untuk menunjukkan arah rotasi optis diberi notasi (+) yang memutar bidang terpolarisasi ke kanan, dan diberi notasi (-) untuk yang memutar bidang terpolarisasi ke kiri.

Contohnya D(+)-glukosa, D(-)-fruktosa.

\section{PENULISAN STRUKTUR CARA FISHER-TOLLENS}

Kenyataannya rumus struktur heksosa tidak merupakan rantai lurus, tetapi antara gugus aldehid atau keton, yaitu pada atom $C_{1}$ pada aldhid dan atom $C_{2}$ pada keton dengan gugus alkohol primer yaitu atom $C_{5}$ atau atom $C$ - $\alpha$ terbentuk jembatan oksigen yang disebut hemiacetal bridge sehingga membentuk struktur cincin tertutup. Cincin tertutup ini mempunyai lima titik sudut, sehingga disebut cincin furanosa dan enam titik sudut disebut cincin piranosa.

Pedoman penulisan cara Fisher adalah aldehid berada di atas, alkohol primer berada di bawah, hidrogen dan hidroksil berada di samping atom C-sentral.

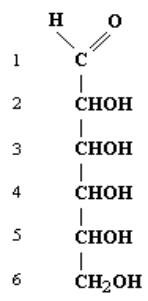

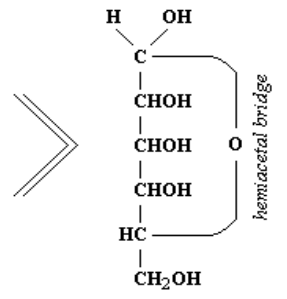

piranosa
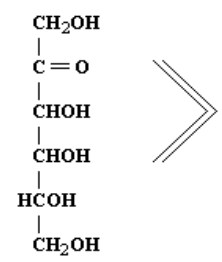

furanosa

Gambar 5-4: Penulisan hemiacetal bridge 
Atom $C$ pada gugus karbonil $\left(C_{1}\right)$ adalah asimetris, sehingga mempunyai $2^{n}=2^{1}=2$ isomer optis. Untuk membedakan kedua isomer optis tersebut diberi notasi $\alpha$ untuk $(-\mathrm{OH})$ yang berada di sisi kanan $\mathrm{C}$-asimetris, dan diberi notasi $\beta$ untuk $(-\mathrm{OH})$ yang berada di sisi kiri C-asimetris.

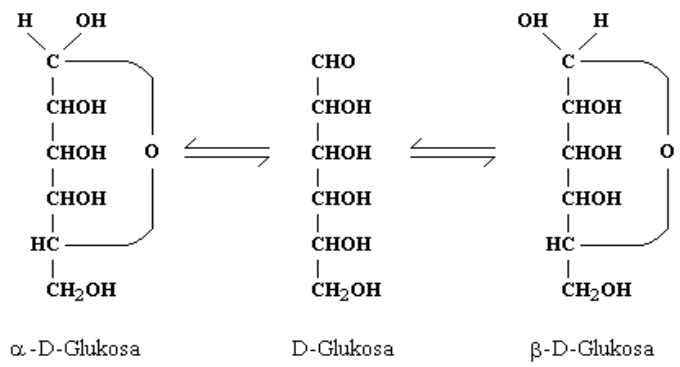

\section{Gambar 5-5: Notasi $\alpha$ dan $\beta$}

Cara lain untuk menentukan bentuk $\alpha$ dan $\beta$ yaitu berdasarkan besarnya sudut rotasi atau rotasi spesifik dengan menggunakan notasi $[\alpha]$. Ketentuan yang digunakan adalah apabila rotasi positif yang makin menurun diberi notasi $\beta$, sedangkan apabila rotasi positif yang makin menaik diberi notasi $\alpha$.

Contoh: D-Clukosa dengan notasi $[\alpha]_{D}^{2^{\circ}}=+19^{\circ}$

maka bentuknya adalah b, jadi namanya b-D-Clukosa.

D-Clukosa dengan notasi $[\alpha]_{D}^{2^{\circ}}=+112^{\circ}$

maka bentuknya adalah $\alpha$, jadi namanya $\alpha$-D-Clukosa

$[\alpha]^{20}=+112^{\circ}$

artinya: $[\alpha] \quad=$ rotasispesifik 


$$
\begin{array}{ll}
D & =- \text { OH berada pada Dextro (kanan) } \\
20 & =\text { suhu pengamatan pada } 20^{\circ} \mathrm{C} \\
+112^{\circ} & =\text { besarnya rotasi spesifik (rotasi positif = ke kanan) }
\end{array}
$$

Misalkan satu jenis bahan mempunyai dua bentuk $\alpha$ dan $\beta$ apabila dibiarkan akan mengalami perubahan rotasi spesifik sampai tercapai keseimbangan, perubahan rotasi ini disebut mutarotasi.

Contoh:

$$
\begin{aligned}
& \alpha-D(+) \text {-Glukosa, }[\alpha] D^{20}=+112^{\circ} \\
& \beta-D(+)-\text { Clukosa, }[\alpha] D^{20}=+19^{\circ}
\end{aligned}
$$

Akan mencapai keseimbangan pada $\mid \alpha]_{D}=+52^{\circ}$

Kebanyakan monosakarida dan beberapa disakarida mengalami mutarotasi. Mutarotasi ini dikatalisa oleh ion-ion $\mathrm{H}^{+}$ dan $\mathrm{OH}^{-}$dan enzim mutarotase yang diekstrak dari Penicillium notatum.

\section{PENULISAN STRUKTUR MONOSAKARIDACARA HAWORTH}

Penulisan struktur cara Haworth berdasarkan pada penulisan strktur cara Fisher. penentuan bentuk $\alpha$ dan $\beta$ pada cara Haworth didasarkan kepada letak gugus - $\mathrm{OH}$ pada atom $\mathrm{C}$, apabila gugus $-\mathrm{OH}$ berada di bawah bidang cincin maka diberi notasi $\alpha$ atau berbentuk $\alpha$, sedangkan apabila gugus $-\mathrm{OH}$ berada di atas bidang cincin diberi notasi $\beta$ atau berbentuk $\beta$ Ketentuan tersebut adalah untuk cincin piranosa. 
Demikian pula untuk cincin furanosa tergantung letak gugus -OH yang terikat pada atom $\mathrm{C}$ seletak dengan bentuk piranosa, akan mempunyai bentuk yang sama dengan ketentuan pada bentuk piranosa.

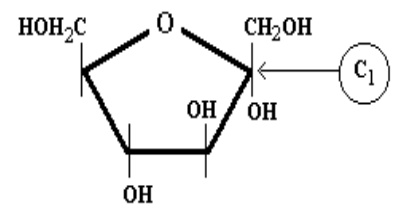

$\alpha-D(-)-$ Fruktofuranosa

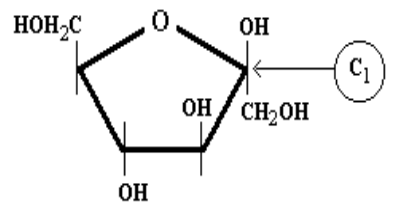

$\beta-D(-)$-Fruktofuranosa

Penentuan bentuk D dan L pada cara Haworth didasarkan kepada letak $\mathrm{C}_{6}$, apabila berada di atas bidang cincin diberi notasi $D$, sedangkan apabila berada di bawah bidang cincin diberi notasi L.

\section{a. HEKSOSA}

Heksosa yang terdapat dalam keadaan bebas pada tanaman dapat berupa aldosa dan ketosa. Pada aldosa terdapat empat atom $\mathrm{C}$-asimetris yaitu $\mathrm{C}_{2}, \mathrm{C}_{3}, \mathrm{C}_{4}, \mathrm{C}_{4}$ maka tiap molekul mempunyai kemungkinan isomer sebanyak $2^{4}=16$ buah isomer.

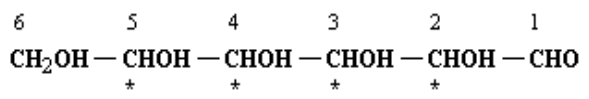

Pada ketosa terdapat tiga atom C-asimetris yaitu $\mathrm{C}_{3}, \mathrm{C}_{4}, \mathrm{C}_{5}$ maka tiap molekul mempunyai kemungkinan isomer sebanyak $2^{3}=8$ buah isomer.

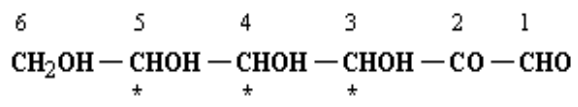


Di antara isomer-isomer yang banyak dijumpai dalam bahan pangan hanya lima buah, yaitu tiga di antaranya berupa aldosa (glukosa, manosa, galaktosa), dan dua yang lain berupa ketosa (fruktosa, sorbosa). Kebanyakan senyawa ini terdapat dalam bentuk siklis beratom $\mathrm{C}=6$ disebut piranosa dan yang lain beratom $\mathrm{C}=5$ disebut furanosa, yang banyak dijumpai di alam berbentuk piranosa.

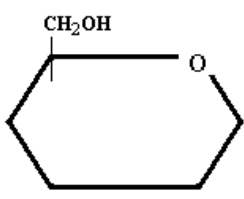

piranosa

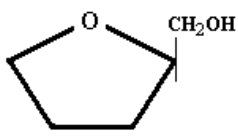

furanosa

Glukosa adalah senyawa gula yang umum terdapat dalam anggur, apel, madu. Senyawa ini mudah mengadakan penetrasi pada buah-buahan yang diawetkan dengan sirup dan juga dapat mempertahankan bentuk, warna, flavor dari buah-buahan. Glukosa komersiil dapat dibuat dengan cara hidrolisa pati jagung dengan $\mathrm{HCl}$ encer dan tekanan serta pemanasan. Glukosa dapat digunakan untuk industri kembang gula. Fruktosa atau levulosa disebut juga fruit sugar adalah berupa ketosa, terdapat dalam madu dan cairan buah dalam bentuk cincin piranosa. Walaupun demikian, bila terdapat bersama-sama dengan gula-gula yang lain misalnya sukrosa atau dalam polisakarida akan membentuk cincinfuranosa. Beberapa struktur heksosa adalah sebagai berikut.

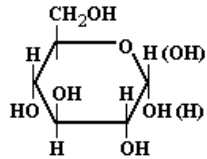

$\alpha$-(B)-D-glukosa

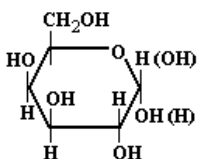

$\alpha-(\beta)-\mathrm{D}$-galaktosa

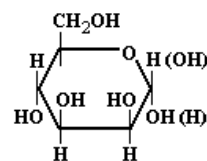

$\alpha-(\beta)-\mathrm{D}-\mathrm{manosa}$

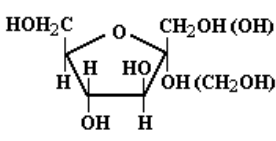

$\alpha-(\beta)$-D-fruktosa 


\section{b. PENTOSA}

Pentosa umumnya berbentuk majemuk, yaitu berupa polisakarida. Dalam senyawa molekul gula tunggal berbentuk piran, sedang dalam senyawa majemuk berbentuk furan. Pentosa yang penting dalam bahan pangan antara lain ribosa, xilosa, arabinosa, rhamnosa.

Pentosa terdapat sebagai pentosan dalam tepung serealia dan rumput laut dan juga merupakan penyusun glikosoda, asam nukleat, koenzim dan lain-lain. Arabinosa terdapat sebagai araban pada beberapa lembaga biji tanaman tertentu, pektin, bit, dan saponin (glukosida). Ribosa adalah penyusun nukleotida, glukosida, dan vitamin $\mathrm{B}_{12}$. Rhamnosa adalah penyusun glukosida seperti selanin pada terung, hesperidin, nsringin pada jeruk, quersetin, dan antosianin.

Beberapa struktur pentosa sebagai berikut.

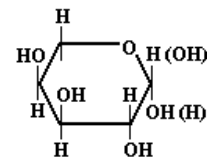

$\alpha-(\beta)-\mathrm{L}$-arabinosa

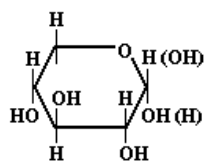

$\alpha-(\beta)-\mathrm{D}-\mathrm{xylosa}$

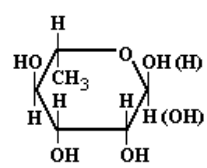

$\alpha-(\beta)$-L-rhamnosa

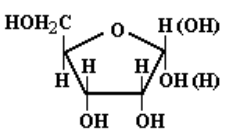

$\alpha-(\beta)$-D-ribosa

\subsubsection{SIFAT FISIS MONOSAKARIDA}

Sifat fisis monosakarida yang penting adalah kelarutan dan aktivitas optik. Monosakarida larut dalam air dan pelarut polar lainnya, tetapi tidak larut dalam eter serta pelarut-pelarut nonpolar. Masing-masing senyawa monosakarida mempunyai aktivitas optik tertentu, sifat ini disebut rotasi optis. Rotasi optis dapat berubah jika suatu larutan karbohidrat mengalami 
konversi dari suatu isomer ke isomer lainnya, proses ini disbut mutarotasi.

\subsubsection{SIFAT REAKSI MONOSAKARIDA}

Reaksi yang penting dalam monosakarida adalah reaksi terhadap gugus karbonil dan reaksi terhadap gugus hidroksil.

\section{a. REAKSI GUGUS KARBONIL}

Gugus karbonil dapat mengalami beberapa reaksi antara lain enolisasi yang juga dikenal sebagai Transformasi Lobry de Bruyn \& Alberda Van Ekenstein. Di samping itu juga oksidasi gugus karbonil, reduksi, pembentukan glikosida.

\section{1). ENOLISASI}

Apabila D-glukosa dipanaskan dalam suasana alkalis akan menghasilkan suatu keseimbangan antara tiga jenis gula, yaitu D-glukosa (65\%), D-fruktosa (31\%), D-manosa (2-4\%) melalui fase intermedier berupa enediol dan yang mengalami transformasi hanya atom $\mathrm{C}_{2}$ saja. Mekanisme reaksinya seperti Gambar 5-6.

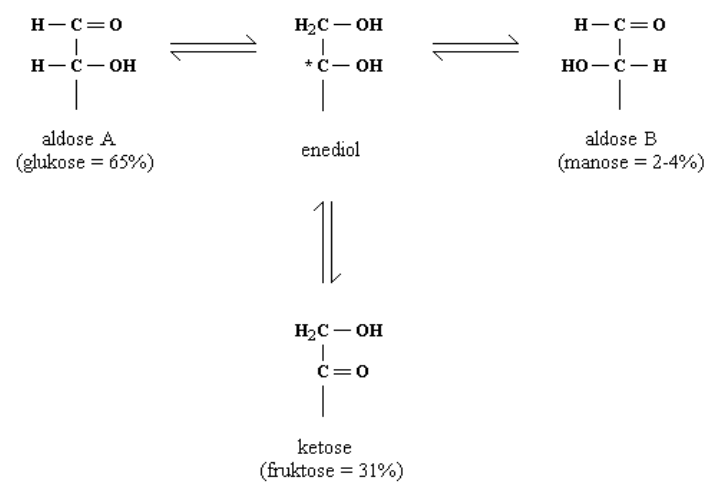

Gambar 5-6: Reaksi enolisasi 


\section{2). OKSIDASI GUGUS KARBONIL}

Monosakarida yang dipanaskan dalam suasana alkalis akan membentuk enediol seperti dibagankan pada Gambar 5-6. Enediol merupakan senyawa yang mudah teroksidasi oleh oksigen dan oksidator akan menghasilkan redukton.

$$
\begin{gathered}
\mathrm{R}-\mathrm{C}=\mathrm{C}-\mathrm{CHO} \\
\text { । } 1 \text { । } \\
\text { OH }
\end{gathered}
$$

redukton

Glukosa dapat teroksidasi oleh enzim oksidase, yaitu glukosa oksidase, secara komersiil menggunakan notatin yang dihasilkan oleh fungi. Oksidasi glukosa oleh enzim oksidase akan menghasilkan glukonat.

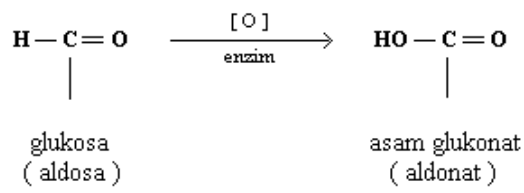

\section{3). REDUKSI}

Senyawa monosakarida jika direduksi akan menghasilkan senyawa alkohol polihidrat (polyol). Polyol berupa kristal padat, larut dalam air, misalnya sorbitol dan manitol. Sorbitol digunakan sebagai pengganti gula bagi penderita diabetes dan juga digunakan dalam industri sorbose, asam sitrat, kembang gula. Ester dari sorbitol asam lemak digunakan sebagai emulsifier. D-sorbitol atau glusitol banyak dijumpai dalam buah-buahan seperti apel, pear, cherry, dan peach. Manitol banyak digunakan dalam industri farmasi. 


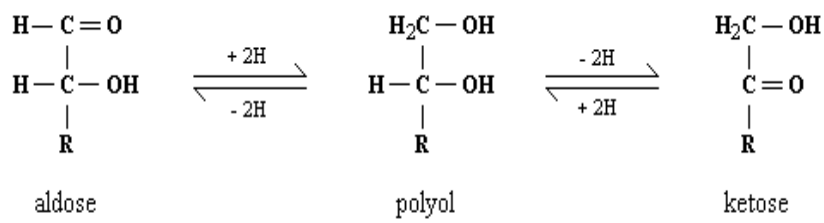

Cambar 5-7: Reduksi monosakarida

\section{4). PEMBENTUKANGLIKOSIDA}

Gugus hidroksil dari gula dapat berkondensasi dengan alkohol dengan cara melepaskan satu molekulair, mekanismenya sebagai berikut.

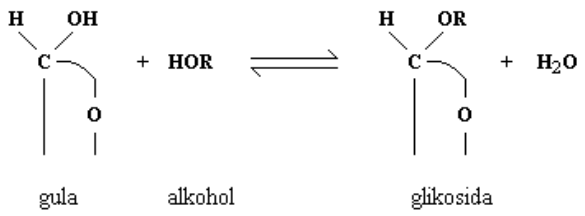

Hasil kondensasi berupa glikosida. Apabila gugus alkohol berupa gula, maka glikosidanya berupa disakarida. Apabila kondensasi berlanjut akan dihasilkan polisakarida. Kalau gugus alkohol bukan gula, maka glikosidanya berupa aglikon.

\section{b. REAKSI GUGUS HIDROKSIL}

Reaksi terhadap gugus hidroksil dalam monosakarida yang penting adalahesterifikasi danoksidasi.

\section{1). ESTERIFIKASI}

Asetilasi dan metilasi sering digunakan untuk menjelaskan strukut kimia dari gula. Esterifikasi umumnya dikatalisa oleh enzim heksokinase. 
glukosa + ATP $\stackrel{\text { hekrsokinase }}{\longrightarrow}$ glukosa-6P + ADP

\section{2). OKSIDASI}

Oksidasi gugus karbonil primer yaitu $\mathrm{C}_{6}$ dari glukosa, galaktosa, dan sebagainya secara enzimatis dengan bantuan katalisator organik akan menghasilkan oksidasi berupa asam glukuronat, asam galakturonat. Asam galakturonat merupakan unit dasar penyusun pectic substances atau senyawa-senyawa pektin. Asam glukuronat penting sebagai bahan anti racun yang dapat mengikat bahan racun melalui ikatan glikosida.

\subsection{OLIGOSAKARIDA}

Oligosakarida berasal dari unsur kata oligo yang artinya beberapa. Oligosakarida merupakan persenyawaan yang terdiri dari dua sampai sepuluh monosakarida. Persenyawaan ini dapat disusun oleh monosakarida sejenis atau berbeda. Oligosakarida yang penting antara lain disakarida dan trisakarida.

\subsubsection{DISAKARIDA}

Disakarida merupakan rantai dua monosakarida melalui ikatan glikosida. Disakarida yang penting sebagai komponen bahan pangan ialah sukrosa, maltosa, laktosa, selobiosa. Sukrosa terdapat dalam gula tebu, gula bit, dan beberapa buah-buahan. Maltosa terdapat dalam kecambah/toge. Laktosa terdapatdalam susu. Selobiosa merupakan penyusun selulosa.

Struktru sukrosa disusun oleh glukosa dan fruktosa, maltosa disusun oleh glukosa dan glukosa, laktosa disusun 
oleh glukosa dan galaktosa, selobiosa disusun oleh glukosa dan glukosa.

Disakarida yang terdapat dalam bentuk bebas di alam adalah sukrosa dan laktosa. Semua disakarida yang lainnya terdapat dalam bentuk polisakarida. Sukrosa sangat mudah terhidrolisa oleh asam dan enzim invertase akan dihasilkan glukosa dan fruktosa. Campuran kedua produk ini disebut gula invert. Sukrosa mempunyai putaran optis $\left[\left.\alpha\right|_{D}=+66,5^{\circ}\right.$, sedangkan gula invert mempunyai putaran optis sebesar $[\alpha]_{D}=-20^{\circ}$, dari kenyataan itu makan proses ini disebut inversi.

Struktur beberapa disakaraida seperti berikut ini.

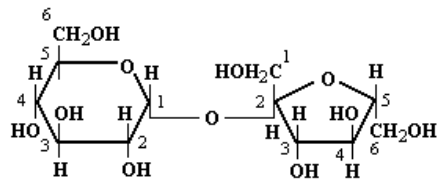

glukosa

Sukrosa ( $\beta$-D-fruktosyl $\alpha$-D-glukosa)

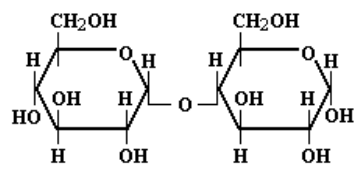

glukosa glukosa

Maltosa [ $\beta$-D-glukcosyl - (1-4)- $\alpha-\mathrm{D}$-glukosa ]

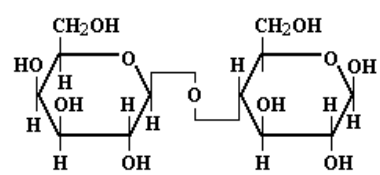

galaktosa

glukosa

Laktosa [ $\beta$-D-galactocyl - (1-4)- $\alpha$-D-glukosa ]

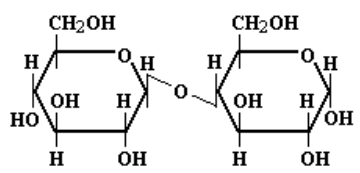

glukosa

glukosa

Selobiose [ $\beta$-D-glukcosyl - (1-4)- $\alpha$-D-glukosa ]

\subsubsection{TRISAKARIDA}

Beberapa Trisakarida dapat dijumpai di alam. Yang penting antara lain rafinosa terdapat dalam cairan buah gula bit dan dalam kulit biji kapas. Rafinosa disusun oleh glukosa + galaktosa + fruktosa. Rafinosa dapat dihidrolisa oleh enzim rafinase 
menghasilkan sukrosa dan galaktosa. Apabila suasananya asam akan terbentuk melibiosa dan fruktosa. Trisakarida lain yang juga terdapat di alam, misalnya gentianosa terdapat dalam akar gentian, melezitosa dalam madu tanaman, plantosa dalam tanaman plantago. Struktur rafinosa digambarkan berikut ini.

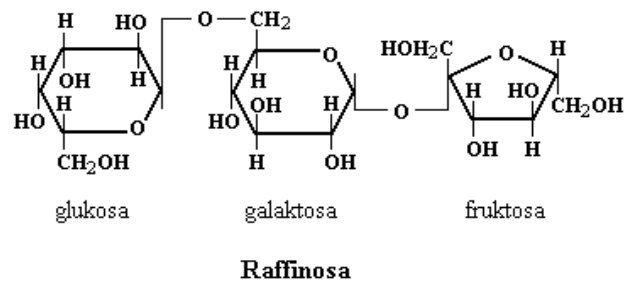

\subsubsection{TETRASAKARIDA}

Salah satu tetrasakarida adalah stachyosa, merupakan heteropolisakarida disusun oleh dua D-galaktosa + D-glukosa + D-fruktosa. Stachyosa banyak dijumpai dalam kedelai. Struktur stachyosa diilustrasikan berikut ini.

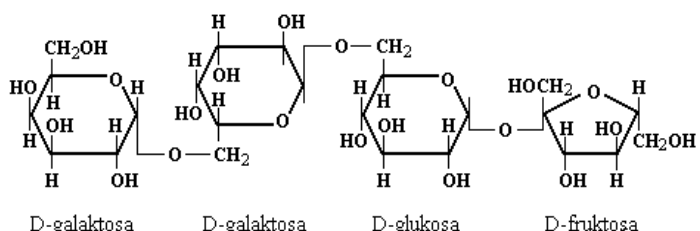

Stachyosa

\subsection{POLISAKARIDA}

Polisakarida merupakan polimer dari monosakarida yang terikat melalui ikatan glikosida. Polisakarida adalah karbohidrat polimer yang terdiri lebih dari sepuluh monosakarida. Sebagian besar polisakarida disusun oleh beberapa ratus hingga ribuan unit monosakarida. 
Polisakarida bersifat amorf, tidak berwarna dan hampir tidak berasa. Pada makhluk hidup, polisakarida merupakan konstituen jaringan struktur, misalnya selulosa dalam tanaman dan asam muramat pada dinding sel bakteri. Pada bahan pangan polisakarida sangat penting dalam kaitannya dengan karakteristik pangan, yaitu berupa karakteristik sensoris misalnya tekstur, viskositas, mouthfeel, konsistensi, gelation, toughness, dan sebagainya.

Struktur rantai polisakarida bisa dalam bentuk rantai lurus, misalnya amilosa, selulosa, atau dalam bentuk rantai bercabang misalnya amilopektin, glikogen.

Berdasarkan struktur kimia-nya polisakarida dapat diklasifikasikan menjadi tiga, yaitu homopolisakarida, heteropolisakarida, dan polisakarida majemuk. Homopolisakarida disusun oleh beberapa unit monosakarida sejenis, misalnya selulosa, pati, glikogen. Heteropolisakarida disusun oleh dua macam komponen atau lebih yang berbeda-beda, misalnya hemiselulosa, pektin, resin. Polisakarida majemuk disusun oleh sakarida dan protein atau lipida, misalnya glikoprotein, asam mukopolisakarida.

\subsubsection{HOMOPOLISAKARIDA}

Beberapa homopolisakarida antara lain selulosa, pati, glikogen.

\section{a. SELULOSA}

Selulosa terdapat pada jaringan dinding sel bersama-sama xilan dan lignin. Selulosa tidak larut dalam air, sangat tahan terhadap reaksi kimia biasa dan tidak dapat dicerna disebut 
crude fibre. Secara kimiawi selulosa merupakan polimer linier dari unit-ubit D-glukosa yang berikatan melalui ikatan $\beta$-(1-4) sebagai selobiosa. Rumus struktur selulosa digambarkan berikut ini.

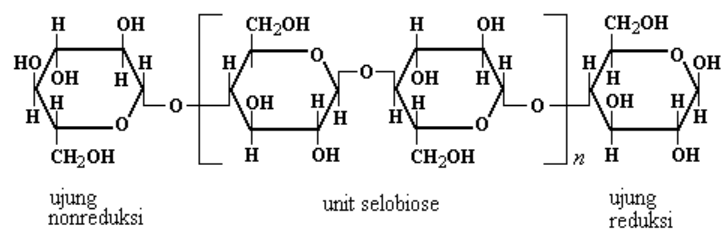

Selulose

\section{b. PATI}

Rumus molekul pati secara pasti belum diketahui. Pati terdapat hampir di semua tanaman pada bagian akar, umbi akar, biji, batang, dan beberapa buah-buahan. Granula pati tidak larut dalam air dingin tetapi akan mengabsorbsi air dan membengkak perlahan-lahan, pembengkakan ini bersifat reversibel misalnya bila dikeringkan maka akan mengkerut.

Berbeda halnya bila pati diperlakukan dengan air mendidih maka pati akan membengkak maksimum hingga pecah, hancur dan dihasilkan bentuk pasta, peristiwa ini disebut gelatinisasi. Suatu dispersi atau pasta mengandung dua macam pati yaitu amilosa dan amilopektin. Apabila dilakukan hidrolisa parsiil oleh asam akan dihasilkan campuran kompleks berupa dextrin, maltosa, dan glukosa. Apabila dilakukan hidrolisa sempurna akan dihasilkan D-glukosa. Dispersi koloid dari pati yang dihidrolisa oleh enzim amilase akan dihasilkan maltosa dan glukosa.

\section{1). AMILOSA}

Amilosa merupakan polimer rantai lurus yang terdiri dari $250-2.000$ glukosa yang berikatan melalui ikatan 
glukosida $\alpha-D-(1-4)$ dan merupakan pengulangan dari unit-unit maltosa. Kandungan amilosa dalam pati dari tanaman yang berbeda akan berbeda pula, misalnya tapioka (17\%), kentang (22\%), jagung (28\%), kacangkacangan (70\%), beras ketan (70\%). Amilosa dengan lodin akan membentuk warna biru cerah. Dalam larutan encer, amilosa-amilosa dengan mudah bergabung membentuk endapan. Molekul rantai lurus ini cenderung bergabung dengan molekul lainnya dalam susunan paralel berikatan melalui jembatan hidrogen sehingga afinitasnya terhadap air menurun, ukuran agregat ini makin membesar yang akhirnya membentuk endapan, peristiwa ini disebut retrogradasi.

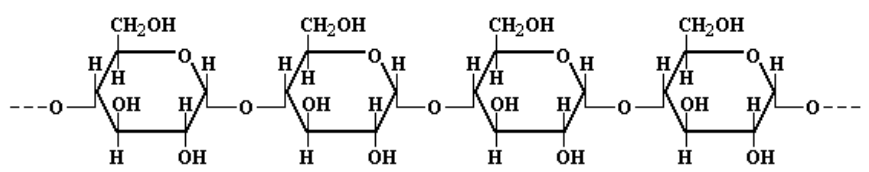

bagian molekul amylosa

\section{2). AMILOPEKTIN}

Amilosa merupakan polimer rantai cabang, setiap cabang dari pengulangan cabang mengandung $15-25$ glukosa yang berikatan $\alpha-(1-4)$ dengan titik-titik cabang ikatan $\alpha-(1-6)$. Amilopektin dengan lodin membentuk warna merah violet. Retrogradasi amilopektin berjalan sangat lambat sehingga amilopektin sangat tahan terhadap pembentukan gel, demikian juga sifat-sifat ikatannya terhadap air. 


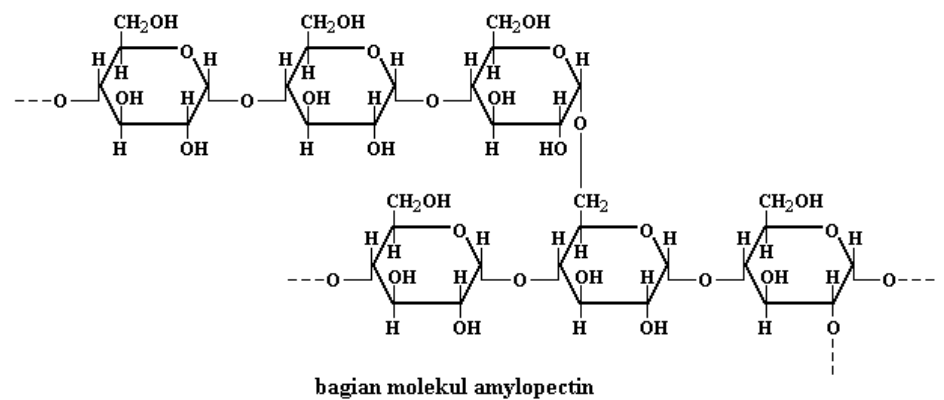

\section{3). DEKSTRIN}

Dextrin merupakan hasil degradasi oleh adanya aktivitas enzim, asam, dan panas.

Terdapat tiga macam dextrin hasil hidrolisa pati, yaitu: amylodextrin atau disebut soluble starch, eritrodextrin, dan achroodextrin. Amylodextrin bila direaksikan dengan lodin akan memberikan warna biru. Eritrodextrin bila direaksikan dengan lodin akan memberikan warna merah. Sedangkan achroodextrin bila direaksikan dengan lodin akan memberikan hasil tidak berwarna. Secara komersiil, soluble starch dibuat dengan memanaskan pati kering pada suhu $(230-260)^{\circ} \mathrm{C}$. Dextrin larut dalam air dan membentuk endapan dalam larutan encer bila ditambah alkohol.

\section{c. GLIKOGEN}

Clikogen merupakan bahan makanan cadangan bagi hewan. Struktur glikogen sama dengan amylopectin, setiap cabang dari pengulangan cabang mengandung 12-18 glukosa yang berikatan $\alpha-(1-4)$ dengan titik cabang ikatan $\alpha-(1-6)$. Clikogen 
berwarna putih, amorf, tidak berasa, apabila dihidrolisa akan menghasilkan dextrin, maltosa, dan glukosa. Clikogen larut dalam air, dengan lodin akan membentuk warna violet-coklat.

\subsubsection{HETEROPOLISAKARIDA}

Heteropolisakarida meliputi musilage, gum, hemiselulosa, dan zat-zat pektin.

\section{a. MUSILAGE}

Termasuk musilage adalah agar dan karagenan. Agar mempunyai sifat membentuk gel, contohnya agar-agar. Agar adalah suatu polisakarida sulfat yang dihasilkan rumput laut, strukturnya belum diketahui dengan pasti. Agar terdiri dari galaktosa, anhidrogalaktosa, dan sedikit ester sulfat. Agar tidak larut dalam air dingin dan alkohol. Agar apabila dipanaskan akan membentuk larutan yang viscous, bila didinginkan akan membentuk gel. Agar digunakan sebagai reagen pengental dalam pengolahan daging dan pengolahan susu.

Komposisi dan sifat karagenan hampir sama dengan agar. Dalam industri susu coklat digunakan untuk mengurangi cocoa, untuk meningkatkan sup dan saus, ditambahkan dalam pie sebagai reagen pengental.

\section{b. GUM}

Gum adalah polisakarida yang mengandung heksosa dan pentosa bersama-sama asam uronat misalnya gum-arabic yang dihasilkan dari kulit kayu pohon akasia. Secara komersiil digunakan dalam industri lem dan foam stabilizer pada pembuatan bir. 


\section{c. HEMISELULOSA}

Hemiselulosa merupakan gabungan dari xilosa, arabinosa, glukosa, manosa, dan galaktosa. Hemiselulosa bersama-sama dengan lignin dan selulosa merupakan penyusun jaringan dinding sel. Ilustrasi potongan rantai hemiselulosa pada tepung gandum disajikan pada gambar berikut ini.

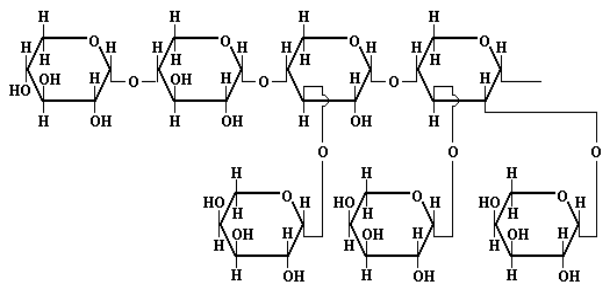

hemiselulosa tepung gandum (potongan)

\section{d. PECTIC SUBSTANCES}

Struktur kimia pectic substrances atau zat-zat pektin belum diketahui dengan pasti. Pektin adalah asam poligalakturonat atau metil esternya. Ilustrasi potongan rantai pectic substance digambarkan berikut ini.

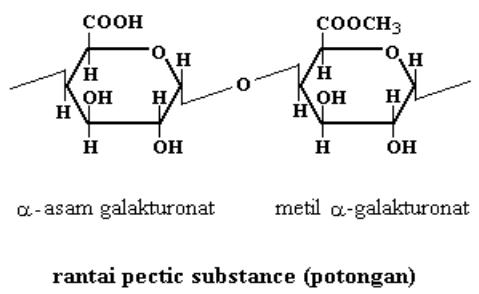

\section{1). PROTOPEKTIN}

Protopektin tidak larut dalam air, merupakan induk senyawa pektin. Bila dihidrolisa menghasilkan asam pektinat. 


\section{2). ASAM PEKTINAT}

Asam pektinat adalah koloid dari asam poligalakturonat yang banyak mengandung metil ester, dengan gula dan asam atau ion logam dapat membentuk gel.

\section{3). PEKTIN}

Pektin yaitu asam pektinat yang larut dalam air dengan berbagai jumlah kandungan metil-ester, dengan gula dan asam pada kondisi tertentu dapat membentuk gel.

\section{4). ASAM PEKTAT}

Asam pektat terdiri dari koloid asam poligalakturonat yang bebas metil ester.

\subsubsection{POLISAKARIDA MAJEMUK}

Beberapa contoh polisakarida majemuk adalah glikoprotein, dan asam mukopolisakarida. Clikoprotein disusun oleh protein sederhana dan bagian karbohidrat yang berikatan secara kovalen. Glikoprotein banyak terdapat dalam kacang kedele, gamma globulin, ovalbumin telur, hormon, dan ribonuklease.

Asam mukopolisakarida misalnya kondroitin sulfat, asam hialuronat dan heparin adalah mukopolisakarida yang berikatan secara kovalen dengan protein yang terdapat pada jaringan pengikat.[] 



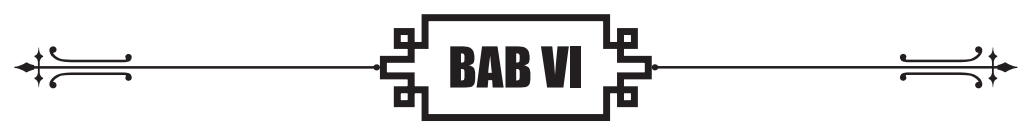

\section{LIP|ПH}

Lipida adalah suatu substansi yang terdapat di alam yang berupa gugusan heterogen yang bersifat relatif tidak larut dalam air tetapi larut dalam pelarut organik seperti eter, khloroform, benzena, dan aseton. Lipida merupakan unsur makanan yang penting. Selain mempunyai energi yang tinggi, juga mengandung vitamin yang larut dalam lemak serta asam lemak esensiil. Lipida disusun oleh C, H, O, kadang-kadang N, P. Kebanyakan lipida berbentuk padatan yang lunak atau cair pada suhu kamar dan sulit mengkristal.

Lemak pangan atau edible fat adalah campuran dari trigliserida dan sedikit substansi lain yang terdapat di alam atau berasal dari proses pengolahan dan penyimpanan lemak. Umumnya lemak dan minyak terdiri dari trigliserida, digliserida, monogliserida, asam lemak, fosfolipida, sterol, vitamin yang larut dalam lemak, pigmen, hidrokarbon, hasil-hasil oksidasi, trace metal dan air.

Lemak yang terdapat di alam kebanyakan merupakan campuran trigliserida dengan sedikit monogliserida dan 
digliserida serta sedikit asam lemak bebas. Sebaliknya lemak yang sudah mengalami proses pengolahan kemungkinan mengandung monogliserida dan digliserida lebih banyak, sampai lebih dari $20 \%$. Untuk mengetahui adanya substansi tersebut, sangat penting misalnya adanya vitamin yang larut dalam lemak, sterol, fosfolipida merupakan penunjuk nilai nutrisi. Adanya asam lemak bebas merupakan penunjuk tingkat hidrolisa trigliserida. Adanya peroksida aldehid dan keton merupakan penunjuk jumlah kerusakan oksidatif yang terjadi dalam lemak. Adanya (sterol, fosfolipida, karotenoid, logam) tertentu akan mendorong terjadinya kerusakan oksidatif pada lemak.

\subsection{KLASIFIKASI}

Berdasarkan cara isolasi dan asal mula biogenetik secara garis besar lipida dapatdiklasifikasikan menjaditiga kelas, yaitu lipida sederhana, lipida campuran, dan derivat lipida.

\subsubsection{LIPIDA SEDERHANA}

Lipida sederhana merupakan ester asam lemak dengan berbagai alkohol yang dikelompokkan menjadi dua, yaitu lemak atau minyak dan lilin atau waxes.

\section{a. LEMAK DAN MINYAK}

Lemak dan minyak adalah ester antara asam lemak rantai panjang (asam mono karboksilat) dengan gliserol. Lemak adalah lipidan berbentuk padat pada suhu kamar, sedangkan minyak berbentuk cair pada suhu kamar. 


\section{b. WAXES (LILIN LIPIDA)}

Waxes adalah ester antara alkohol monohidrat rantai panjang atau yang mempunyai berat molekul besar sebagai pengganti gliserol dengan asam lemak rantai panjang. Waxes mempunyai titik lebur tinggi. Waxes atau lilin di sini berbeda dengan lilin parafin yang dihasilkan dari minyak bumi.

\subsubsection{LIPIDA CAMPURAN}

Lipida campuran adalah ester asam lemak dengan asam lemak yang mengandung gugus tambahan selain alkohol atau lipida sederhana yang mengikat molekul-molekul bukan lipida.

\section{a. FOSFOLIPIDA}

Fosfolipida adalah ester asam lemak dan alkohol yang mengandung asam fosfat sebagai pengganti satu molekul asam lemak, di samping itu juga mengandung basa nitrogen. Misalnya asam fosfatidat merupakan gliserida yang disusun oleh satu mole asam fosfor dan dua mole asam lemak.

Contoh lainnya lesitin atau fosfatidil kholin dan sefalin atau fosfatidil etanol amin atau fosfatidil etanol serin.

\section{b. GLIKOLIPIDA}

Clikosida merupakan campuran antara asam lemak dengan karbohidrat. Clikolipida mengandung nitrogen tetapi tidak mengandung asam fosfat. 


\section{c. LIPOPROTEIN}

Lipoprotein merupakan senyawa kompleks dari berbagai senyawa lipida dengan senyawa protein. Termasuk pula dalam lipoprotein adalah aminolipida.

\subsubsection{DERIVAT LIPIDA}

Derivat lipida merupakan zat yang diturunkan dari senyawa-senyawa golongan di atas dengan cara hidrolisa. Termasuk dalam derivat lipida antara lain asam-asam lemak (asam lemak jenuh dan asam lemak tidak jenuh), alkohol (alkohol rantai panjang atau alkohol siklis yang tidak larut dalam air misalnya sterol dan vitamin A), hidrokarbon-hidrokarbon (misalnya karotenoid), dan vitamin-vitamin yang larut dalam lemak (misalnya vitamin A, vitamin D, vitamin $\mathrm{E}$, dan vitamin $\mathrm{K}$ ).

\subsection{ASAM LEMAK}

Komponen utama lipida adalah asam karboksilat alifatis berupa asam lemak. Asam lemak adalah asam karboksilat yang diperoleh dari hidrolisa ester, terutama gliserol dan kolesterol. Asam lemak dibedakan menjadi dua kelompok, yaitu asam lemak jenun (rantainya tidak mengandung ikatan rangkap) dan asam lemak tidak jenuh (rantainya mengandung satu ikatan rangkap atau lebih). Asam lemak yang terdapat di alam biasanya mengandung atom karbon genap dan merupakan derivat berantai lurus dengan rantai atom $C$ antara 4 sampai 28 yang banyak dijumpai dalam lemak dan minyak. Asam lemak yang mempunyai rantai atom $\mathrm{C}$ lebih dari 28 banyak dijumpai dalam waxes. Asam lemak mempunyai rantai lurus, tidak bercabang, 
dan tidak tersubstitusi walaupun substitusi-OH, sedangkan yang berbentuk siklis dan bercabang jarang dijumpai.

\subsubsection{TATA NAMA}

Tata nama sistemik yang paling sering digunakan adalah didasarkan atas nama asam lemak sesuai dengan jumlah karbon dari hidrokarbon yang dikandungnya. Untuk asam lemak jenuh namanya diakhiri dengan -anoat, sedang untuk asam lemak tidak jenuh diakhiri dengan -enoat. Atom-atom karbon diberi nomer mulai dari atom karbon karboksil (diberi nomer 1), sedangkan atom-atom yang berdekatan dengan karbon karboksil (diberi nomer 2) dan seterusnya. Atom karbon nomer 2 juga dikenal sebagai karbon- $\alpha$ atom karbon nomer 3 disebut karbon- $\beta$ dan seterusnya, sedang atom karbon yang terakhir dikenal sebagai karbon- $\omega$. Sebagai gambaran penomeran atom karbon tersebut disajikan pada Cambar 6-1.

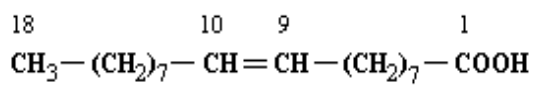

\subsubsection{ASAM LEMAKJENUH}

Beberapa asam lemak jenuh yang telah diisolasi disajikan dalam Tabel 6-1. Setiap asam lemak mempunyai sifat fisis yang berbeda-beda sesuai dengan jumlah atom C-nya. Asam lemak yang mempunyai atom $C$ kurang dari 12 digolongkan sebagai asam lemak volatil atau mudah menguap, sementara yang mempunyai atom $\mathrm{C}$ lebih dari 10 mempunyai bentuk padat pada suhu kamar. Semakin panjang rantai atom Cyang dimiliki, maka kelarutannya dalam air semakin kecil dan asam lemakyang mempunyai atom $C$ lebih dari 10 secara praktis bersifat tidak larut dalam air. 


\section{Tabel 6-1: Klasifikasi asam lemak}

\begin{tabular}{|c|c|c|c|c|c|}
\hline No. & $\begin{array}{c}\text { Jumlah } \\
\text { atom }\end{array}$ & Nama Latin & Nama Sistemik & Rumus Molekul & Terdapat pada \\
\hline \multirow{2}{*}{\multicolumn{6}{|c|}{ I. ASAM LEMAKJENUH }} \\
\hline & & & & & \\
\hline 1. & 4 & Butirat & Butanoat & $\mathrm{CH}_{3}-\left(\mathrm{CH}_{2}\right)_{2}-\mathrm{COOH}$ & lemak mentega \\
\hline 2. & 6 & Kaproat & Heksanoat & $\mathrm{CH}_{3}-\left(\mathrm{CH}_{2}\right) 4-\mathrm{COOH}$ & $\begin{array}{l}\text { mentega, kelapa, } \\
\text { dan minyak palm }\end{array}$ \\
\hline 3. & 8 & Kaprilat & Oktanoat & $\mathrm{CH}_{3}-\left(\mathrm{CH}_{2}\right) 6-\mathrm{COOH}$ & $\begin{array}{l}\text { m.kelapa, } \\
\text { m.palm, dan } \\
\text { mentega }\end{array}$ \\
\hline 4. & 10 & Kaprat & Dekanoat & $\mathrm{CH}_{3}-\left(\mathrm{CH}_{2}\right) 8-\mathrm{COOH}$ & $\begin{array}{l}\text { m.kelapa, } \\
\text { m.palm, } \\
\text { dan mentega }\end{array}$ \\
\hline 5. & 12 & Laurat & Dodekanoat & $\begin{array}{l}\mathrm{CH}_{3}-(\mathrm{CH} 2) 10- \\
\mathrm{COOH}\end{array}$ & $\begin{array}{l}\text { m.kelapa, } \\
\text { m.palm, } \\
\text { dan mentega }\end{array}$ \\
\hline 6. & 14 & Miristat & Tetradekanoat & $\begin{array}{l}\mathrm{CH}_{3}-\left(\mathrm{CH}_{2}\right) 12- \\
\mathrm{COOH}\end{array}$ & $\begin{array}{l}\text { m.kelapa, palm, } \\
\text { dan lemak } \\
\text { hewani, naba-ti } \\
\text { tertentu }\end{array}$ \\
\hline 7. & 16 & Palmitat & Heksadekanoat & $\begin{array}{l}\mathrm{CH}_{3}-\left(\mathrm{CH}_{2}\right) 14- \\
\mathrm{COOH}\end{array}$ & $\begin{array}{l}\text { hampir semua } \\
\text { lemak nabati dan } \\
\text { hewani }\end{array}$ \\
\hline 8. & 18 & Stearat & Oktadekanoat & $\begin{array}{l}\mathrm{CH}_{3}-\left(\mathrm{CH}_{2}\right) 16- \\
\mathrm{COOH}\end{array}$ & $\begin{array}{l}\text { lemak hewani, } \\
\text { kom-ponen } \\
\text { lemak nabati }\end{array}$ \\
\hline 9. & 20 & Arakhidat & Eikosanoat & $\begin{array}{l}\mathrm{CH}_{3}-\left(\mathrm{CH}_{2}\right) 18- \\
\mathrm{COOH}\end{array}$ & m. kacang tanah \\
\hline 10. & 22 & Behenat & Dokosanoat & $\begin{array}{l}\mathrm{CH}_{3}-\left(\mathrm{CH}_{2}\right) 2 \mathrm{O}- \\
\mathrm{COOH}\end{array}$ & $\begin{array}{l}\text { m.mustar, } \\
\text { m.lobak,m. } \\
\text { kacang tanah }\end{array}$ \\
\hline 11. & 24 & Lignoserat & Tetrakosanoat & $\begin{array}{l}\mathrm{CH}_{3}-(\mathrm{CH} 2)_{22-} \\
\mathrm{COOH}\end{array}$ & $\begin{array}{l}\text { kebanyakan } \\
\text { lemak, sedikit } \\
\text { terdapat dlm. m. } \\
\text { kacang tanah }\end{array}$ \\
\hline
\end{tabular}




\begin{tabular}{|c|c|c|c|c|c|}
\hline 12. & 26 & $\begin{array}{l}\text { Asam } \\
\text { Serotat }\end{array}$ & Heksakosanoat & $\begin{array}{l}\mathrm{CH}_{3}-\left(\mathrm{CH}_{2}\right) 24- \\
\mathrm{COOH}\end{array}$ & lemak wool \\
\hline \multicolumn{6}{|c|}{ B. Asam lemak rantai cabang: } \\
\hline \multirow{3}{*}{1.} & \multirow{3}{*}{5} & \multirow{3}{*}{ Isovalerat } & 3-Metil butanoat & $\begin{array}{l}(\mathrm{CH} 3)_{2}-\mathrm{CH}-\mathrm{CH}_{2}- \\
\mathrm{COOH}\end{array}$ & $\begin{array}{l}\text { lemakikan } \\
\text { dolphin, } \\
\text { dan ikan porpoise }\end{array}$ \\
\hline & & & $\begin{array}{l}\text { 11-Metil } \\
\text { dodekanoat }\end{array}$ & $\begin{array}{l}(\mathrm{CH})_{2}-\mathrm{CH}-\left(\mathrm{CH}_{2}\right) 9- \\
\mathrm{COOH}\end{array}$ & mentega \\
\hline & & & $\begin{array}{l}\text { 13-Metil } \\
\text { tetradekanoat }\end{array}$ & $\begin{array}{l}\left(\mathrm{CH}_{3}\right) 2-\mathrm{CH}-\left(\mathrm{CH}_{2}\right) 11- \\
\mathrm{COOH}\end{array}$ & mentega \\
\hline \multirow{2}{*}{\multicolumn{6}{|c|}{$\begin{array}{l}\text { II. ASAM LEMAK TIDAKJENUH } \\
\text { oat (1 ikatan ranakap): }\end{array}$}} \\
\hline & & & & & \\
\hline 1. & 10 & Kaproleat & 9-Desenoat & $\mathrm{C} 9 \mathrm{H}_{17}-\mathrm{COOH}$ & lemak susu \\
\hline 2. & 12 & Lauroleat & 9-Dodesenoat & $\mathrm{C}_{11} \mathrm{H}_{21}-\mathrm{COOH}$ & lemak susu \\
\hline 3. & 14 & Miristoleat & 9-Tetradesenoat & $\mathrm{C}_{13} \mathrm{H}_{25}-\mathrm{COOH}$ & $\begin{array}{l}\text { lemak hewani, } \\
\text { susu }\end{array}$ \\
\hline 4. & 14 & Fiseterik & 5-Tetradesenoat & $\mathrm{C}_{13} \mathrm{H} 25-\mathrm{COOH}$ & m.sardin, dolphin \\
\hline 5. & 16 & Palmitoleat & 9-Heksadesenoat & $\mathrm{C}_{15} \mathrm{H} 29-\mathrm{COOH}$ & m. hewan laut \\
\hline 6. & 18 & Oleat & $\begin{array}{l}\text { cis-9- } \\
\text { Oktadesenoat }\end{array}$ & $\mathrm{C}_{17} \mathrm{H}_{33}-\mathrm{COOH}$ & $\begin{array}{l}\text { L. hewani dan } \\
\text { nabati }\end{array}$ \\
\hline 7. & 18 & Elaidat & $\begin{array}{l}\text { trans-9- } \\
\text { Oktadesenoat }\end{array}$ & $\mathrm{C}_{17} \mathrm{H}_{33}-\mathrm{COOH}$ & lemak hewani \\
\hline 8. & 18 & Petraselenat & 6-Oktadesenoit & $\mathrm{C}_{17} \mathrm{H}_{33}-\mathrm{COOH}$ & $\begin{array}{l}\text { m.biji peterseli, } \\
\text { dan m. biji } \\
\text { koriander }\end{array}$ \\
\hline 9. & 18 & Vassernat & $\begin{array}{l}\text { trans-11- } \\
\text { Oktadesenoat }\end{array}$ & $\mathrm{C}_{17} \mathrm{H}_{33}-\mathrm{COOH}$ & sedikit \\
\hline 10. & 18 & Vassernat & 12-Oktadesenoat & $\mathrm{C}_{17} \mathrm{H}_{33}-\mathrm{COOH}$ & sedikit \\
\hline 11. & 20 & Gadoleat & 9-Eikosenoat & $\mathrm{C}_{18} \mathrm{H}_{37}-\mathrm{COOH}$ & $\begin{array}{l}\text { minyak ikan dan } \\
\text { binatang laut }\end{array}$ \\
\hline 12. & 22 & Setoleat & 11-Dokosenoat & $\mathrm{C}_{21} \mathrm{H}_{41}-\mathrm{COOH}$ & m. hewan laut \\
\hline 13. & 22 & Erusat & 13-Dokosenoat & $\mathrm{C}_{21} \mathrm{H}_{41}-\mathrm{COOH}$ & $\begin{array}{l}\text { m.lobak, } \\
\text { m.mustar }\end{array}$ \\
\hline
\end{tabular}




\begin{tabular}{|c|c|c|c|c|c|}
\hline 14. & 24 & Salakoleat & 15-Tetrakosenoat & $\mathrm{C} 23 \mathrm{H} 45-\mathrm{COOH}$ & $\begin{array}{l}\text { minyak hati ikan, } \\
\text { minyak hewan } \\
\text { laut }\end{array}$ \\
\hline \multicolumn{6}{|c|}{ B. Asam dietanoat ( 2 ikatan rangkap): } \\
\hline 1. & 18 & Linoleat & 9,12-Oktadekadienoat & $\mathrm{C}_{17} \mathrm{H}_{31}-\mathrm{COOH}$ & $\begin{array}{l}\text { m.kacang, m.biji- } \\
\text { rami, m.biji kapas }\end{array}$ \\
\hline
\end{tabular}

Tabel 6-1: Klasifikasi asam lemak (lanjutan)

\begin{tabular}{|c|c|c|c|c|c|}
\hline No. & $\begin{array}{l}\text { Jumlah } \\
\text { atom }\end{array}$ & Nama Latin & Nama Sistemik & Rumus Molekul & $\begin{array}{l}\text { Terdapat } \\
\text { pada }\end{array}$ \\
\hline \multicolumn{6}{|c|}{ C. Asam trietanoat ( 3 ikatan rangkap): } \\
\hline 1. & 18 & Linoleat & $\begin{array}{l}9,12,15- \\
\text { Oktadekatrienoat }\end{array}$ & $\mathrm{C}_{17} \mathrm{H}_{29}-\mathrm{COOH}$ & $\begin{array}{l}\text { m.bj.rami, } \\
\text { m.bijian }\end{array}$ \\
\hline 2. & 18 & Oleostearat & $\begin{array}{l}9,11,13- \\
\text { Oktadekatrienoat }\end{array}$ & $\mathrm{C}_{17} \mathrm{H} 29-\mathrm{COOH}$ & $\begin{array}{l}\text { lemak biji } \\
\text { kacang }\end{array}$ \\
\hline \multicolumn{6}{|c|}{ D. Asam tetraetanoat ( 4 ikatan rangkap): } \\
\hline 1. & 18 & Morostat & $\begin{array}{l}4,8,12,15- \\
\text { Oktadekatetraenoat }\end{array}$ & $\mathrm{C}_{17} \mathrm{H}_{27}-\mathrm{COOH}$ & minyak ikan \\
\hline 2. & 20 & Arakhidonat & $\begin{array}{l}5,8,11,15- \\
\text { Eikosatetraenoat }\end{array}$ & $\mathrm{C}_{19} \mathrm{H}_{31}-\mathrm{COOH}$ & $\begin{array}{l}\text { sedikit Imk. } \\
\text { hewani }\end{array}$ \\
\hline \multicolumn{6}{|c|}{ E. Asam polietanoat (banyak ikatan rangkap): } \\
\hline 1. & 22 & Klupanodonat & $\begin{array}{l}\text { 4,8,12,15,19- } \\
\text { Dokosapentaenoat }\end{array}$ & $\mathrm{C}_{21} \mathrm{H} 33-\mathrm{COOH}$ & minyakikan \\
\hline 2. & 24 & Nisinat & $\begin{array}{l}4,8,12,15,18,21- \\
\text { Tetrakosaheksanoat }\end{array}$ & $\mathrm{C} 23 \mathrm{H} 35-\mathrm{COOH}$ & $\begin{array}{l}\text { minyak } \\
\text { sardin, dan } \\
\text { minyak ikan } \\
\text { lainnya }\end{array}$ \\
\hline
\end{tabular}




\begin{tabular}{|c|l|l|l|l|l|}
\hline \multicolumn{5}{|c|}{ III.ASAM LEMAK TIDAKJENUH MONOHIDROKSI } \\
\hline 1. & 18 & Risinoleat & $\begin{array}{l}\text { 12-Hidroksi-cis-9- } \\
\text { Oktadesenoat }\end{array}$ & $\begin{array}{l}\text { HOC17H32- } \\
\text { COOH }\end{array}$ & $\begin{array}{l}\text { minyak biji } \\
\text { kacang, } \\
\text { m.kastroli } \\
\text { (m.jarak) }\end{array}$ \\
\hline 1. & & $\begin{array}{l}\text { Asam } \\
\text { Laktobasilik }\end{array}$ & $\begin{array}{l}\text { W-(2-n- } \\
\text { Oktilsiklopropil)- } \\
\text { asam oktanoat }\end{array}$ & mikroorganisme \\
\hline 3. & Asam & $\begin{array}{l}\text { W-(2-n- } \\
\text { Oktilsiklopropil- } \\
1-\text {-nil)- asam } \\
\text { oktanoat }\end{array}$ & m. biji tanaman \\
\hline Sterkulat & $\begin{array}{l}\text { W-(2-n- } \\
\text { Oktilsiklopropil- } \\
1-\text {-enil)- asam } \\
\text { heptanoat }\end{array}$ & m. biji tanaman \\
\hline
\end{tabular}

\subsubsection{ASAM LEMAK TIDAK JENUH}

Asam lemak tidak jenuh banyak dijumpai dalam minyak yang diperoleh dari sumber nabati. Umumnya berupa asam lemak rantai lurus dengan jumlah atom C antara 10-24. Beberapa di antaranya disajikan dalam Tabel 6-1.

Isomerisasi dapat terjadi pada asam lemak tidak jenuh yang dipengaruhi oleh jumlah ikatan angkap, posisi ikatan rangkap, dan bentuk cis dan trans.

Asam lemak yang mempunyai dua ikatan rangkap atau lebih disebut polyunsaturated fatty acid atau asam lemak tidak jenuh tinggi misalnya asam linoleat, asam linolenat, asam arakhidonat. Asam lemak tidak jenuh tinggi ini mempunyai 
peranan tertentu dalam fungsi fisiologis, biasanya disebut asam lemak esensiil, di antaranya yang penting misalnya asam linoleat. Tetapi asam lemak esensiil tidak dapat disintesa dalam tubuh dengan cepat. Oleh karena itu, harus disediakan dari makanan yang dikonsumsi.

\subsubsection{ASAM LEMAK SIKLIS, BERCABANG, TERSUBSTITUSI}

\section{a. ASAM LEMAK SIKLIS}

Asam lemak berbentuk siklis hanya sedikit dijumpai di alam misalnya asam malvalat. Asam malvalat terdapat dalam minyak biji kapas dan minyak lain yang diperoleh dari tanaman malvalaceae. Asam malvalat mempunyai gugus siklopropenil yang mempunyai rantai tertutup dan berada pada tengah-tengah rantai molekul. Rumus struktur asam malvalat (asam lemak siklis) disajikan pada Gambar 6-2.

$$
\mathrm{CH}_{3}-\left(\mathrm{CH}_{2}\right)_{6}-\mathrm{C}=\mathrm{C}-\left(\mathrm{CH}_{2}\right)_{7}-\mathrm{COOH}
$$

asam malvalat

\section{Gambar 6-2: Asam lemak siklis}

\section{b. ASAM LEMAK BERCABANG}

Asam lemak bercabang dapat dijumpai dalam minyak dolphin, porpoise, lemak domba, wool, mentega, dan beberapa lipida pada bakteri. Biasanya gugus cabangnya berupa metil, misalnya isovalerat atau b-metil butirat atau 3-metil butirat. Rumus struktur 
asam isovalerat (asam lemak bercabang) disajikan pada Cambar 6-3.

$$
\begin{gathered}
\mathrm{CH}_{3}-\underset{\mid}{\mathrm{CH}}-\mathrm{CH}_{2}-\mathrm{COOH} \\
\mathrm{CH}_{2} \\
\text { isovalerat }
\end{gathered}
$$

\section{Gambar 6-3: Asam lemak bercabang}

\section{c. ASAM LEMAKTERSUBSTITUSI}

Asam lemak tersubstitusi misalnya tersubstitusi hidroksil, contoh asam risinolenat. Asam risinolenat banyak terdapat dalam minyak kastor (80-85)\%. Karena gugus hidroksil ini reaktif, maka asam risinolenat sangat diperlukan sebagai bahan baku untuk sintesa polimer plastik tertentu. Rumus struktur asam risinoleat (asam lemak tersubstitusi) disajikan pada Gambar 6-4.

$$
\begin{gathered}
\mathrm{CH}_{3}-\left(\mathrm{CH}_{2}\right)_{5}-\mathrm{CH}_{2}-\mathrm{CH}_{2}-\underset{\text { l }}{\mathrm{C}}=\mathrm{CH}-\left(\mathrm{CH}_{2}\right)_{7}-\mathrm{COOH} \\
\text { OH }
\end{gathered}
$$

asam risinoleat

\section{Gambar 6-4: Asam lemak tersubstitusi}

\subsubsection{ISOMERISASI}

Isomerisasi geometrik tergantung pada orientasi atom atau gugus sekitar poros ikatan rangkap. Perbedaan antar senyawa isomer hanya pada orientasi bagian-bagian sekitar poros ini. Jika radikal-radikal sekitar poros terletak pada sisi yang sama, maka senyawa disebut sis, sedang jika terletak pada sisi yang berseberangan atau berlawanan, maka senyawa berbentuk 
trans. Isomerisasi dapat terjadi karena berbagai sebab, yaitu yang diakibatkan oleh susunan rantai asam lemak (lurus atau bercabang), posisi ikatan rangkap, dan bentuk geometri.

\section{a. SUSUNAN RANTAI ASAM LEMAK}

Isomerisasi yang disebabkan oleh susunan atom C dalam asam lemak yaitu mempunyai susunan lurus atau bercabang, misalnya pada asam butirat dan iso butirat. Rumus struktur bentuk isomer tersebut diilustrasikan pada Gambar 6-5.

$$
\mathrm{CH}_{3}-\mathrm{CH}_{2}-\mathrm{CH}_{2}-\mathrm{COOH}
$$

asam butirat<smiles>CC(C)C(=O)O</smiles>

asam isobutirat

\section{Gambar 6-5: Isomer susunan rantai asam lemak}

\section{b. POSISIIKATAN RANGKAP}

Isomerisasi dapat disebabkan oleh posisi ikatan rangkap dalam rantai asam lemak tidakjenuh, misalnya antara asam oleat dan isooleat. Rumus struktur bentuk isomer berdasarkan posisi ikatan rangkap diilustrasikan pada Gambar 6-6.

$$
\begin{aligned}
& \mathrm{CH}_{3}-\left(\mathrm{CH}_{2}\right)_{7}-\mathrm{CH}=\mathrm{CH}-\left(\mathrm{CH}_{2}\right)_{7}-\mathrm{COOH} \quad \text { ( asam oleat) } \\
& \mathrm{CH}_{3}-\left(\mathrm{CH}_{2}\right)_{4}-\mathrm{CH}=\mathrm{CH}-\left(\mathrm{CH}_{2}\right)_{10}-\mathrm{COOH} \quad \text { ( asam isooleat) }
\end{aligned}
$$

Gambar 6-6: Isomer posisi ikatan rangkap 
Apabila ikatan rangkapnya lebih dari satu dapat berbentuk konyugasi dan nonkonyugasi, seperti pada Cambar 6-7.

$$
\begin{array}{cc}
-\mathrm{C}=\mathrm{C}-\mathrm{C}=\mathrm{C}-\mathrm{C}- & -\mathrm{C}=\mathrm{C}-\mathrm{C}-\mathrm{C}=\mathrm{C}- \\
\text { konyugasi } & \text { nonkonyugasi }
\end{array}
$$

Cambar 6-7: Isomer konyugasi dan nonkonyugasi

\section{c. BENTUK GEOMETRI}

Isomerisasi pada asam lemak tidak jenuh yang disebabkan bentuk geometri adalah bentuk sis dan trans, misalnya antara asam oleat dan elaidat, antara maleat dan fumarat, dan sebagainya. Pada Cambar 6-8 diilustrasikan bentuk isomer antara asam oleat (cis) dan asam elaidat (trans), serta bentuk isomer asam maleat (cis) dan asam fumarat (trans).

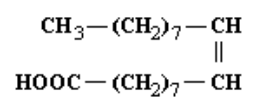

asam oleat ( cis )

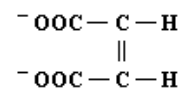

asam maleat ( cis )
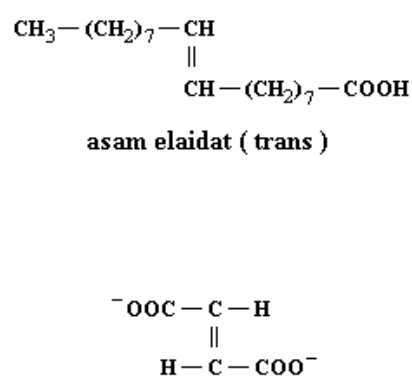

asam fumarat ( trans )

\section{Gambar 6-8: Isomerisasi bentuk geometri}

Di alam umumnya asam lemak tidak jenuh mempunyai bentuk cis, sementara bentuk trans sangat sedikit. 


\subsection{LEMAK DAN MINYAK}

\subsubsection{KOMPOSISI}

Lipida pangan yang penting adalah lemak dan minyak berupa gliserida. Cliserida adalah ester antara gliserol (alkohol) dan asam lemak. Dalam lemak dan minyak ketiga gugus hidroksil $(-\mathrm{OH})$ dalam molekul gliserol berikatan dengan asam lemak dengan ikatan ester, sehingga disebut trigliserida atau gliserida netral. Nama trigliserida ini menurut terminologi standar dari Internatiomal Union of Pure and Applied Chemistry (IUPAC) dan juga dari International Union of Biochemistry (IUB) disebut triasilgliserol, demikian juga digliserida disebut diasilgliserol dan monogliserida disebut monoasilgliserol. Reaksi esterifikasi tersebut disajikan dalam Gambar 6-9.

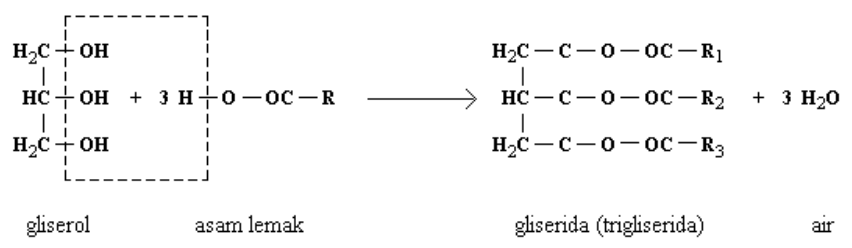

\section{Gambar 6-9: Esterifikasi trigliserida}

Perbedaan antara lemak dan minyak adalah perbedaan bentuk pada suhu kamar. Lemak berbentuk padat pada suhu kamar, sedangkan minyak berbentuk cair pada suhu kamar.

Substansi yang larut dalam lipida antara lain pigmen, seperti khlorofil dan karotenoid, hasil oksidasi seperti aldehid dan keton, asam lemak bebas, sterol, dan sebagainya. Dalam minyak pangan, komponen-komponen selain minyak perlu dihilangkan dengan cara proses refining, yaitu permurnian minyak. 
Penentuan komposisi asam lemak dapat ditentukan melalui hidrolisa dengan alkali yang disebut soponifikasi. Dalam saponifikasi asam lemak berasidifikasi atau bereaksi dengan basa membentuk garam berupa sabun dan hasil lain berupa gliserol. Penentuan jenis atau macam asam lemak penyusunnya melalui reaksi kimia sangat sulit. Oleh karena itu, teknik yang memadai adalah dengan metode Cass Liquid Chromatography (GLC) dan Thin Layer Chromatography (TLC).

Dalam saponifikasi dikenal angka saponifikasi, yaitu banyaknya alkali yang dibutuhkan untuk menghidrolisa satu gram lemak. Saponifikasi ini terutama digunakan untuk mengukur berat molekul rata-rata dari asam lemak. Lemak yang banyak mengandung asam lemak berberat molekul rendah akan menghasilkan angka penyabunan lebih tinggi. Hal ini dapat dijelaskan bahwa pada berat molekul sama besarnya tentunya kandungan asam lemak yang berberat molekul lebih rendah, lebih banyak daripada yang mengandung asam lemak berberat molekul lebih tinggi, sehingga memerlukan lebih banyak alkali untuk reaksi hidrolisanya.

Penentuan banyaknya ikatan rangkap dapat ditentukan dengan cara lodifikasi, yaitu oksidasi ikatan rangkap pada asam lemak. Dalam hal ini dikenal ukuran angka lodin, yaitu jumlah halogen (misalnya lodin) yang dapat bereaksi dengan 100 gram minyak. Hal ini sebanding dengan banyaknya ikatan rangkap atau ikatan tidak jenuh.

\subsubsection{SIFAT FISIS}

Trigliserida murni tidak berwarna, tidak berasa, tidak berbau dan tidak larut dalam air. Adanya warna, bau, dan rasa pada 
lemak dan minyak menunjukkan adanya komponen-komponen bukan trigliserida. Trigliserida yang banyak mengandung asam lemak tidak jenuh mempunyai titik cair lebih rendah. Gliserida dapat berada dalam bentuk kristal yang berbeda-beda disebut polimorfisme.

Karakteristik kristal dan sifat pencairan lemak tidak hanya dipengaruhi oleh komposisi asam lemak saja, tetapi juga dipengaruhi oleh penyebaran asam lemak di antara molekulmolekul trigliserida. Sehingga suatu campuran asam lemak atau minyak yang berbeda akan memberikan konsistensi dan sifat pencairan setiap campuran berbeda-beda pula. Sifat demikian ini dapat dimanfaatkan untukmengembangkan produk baru dengan sifat fisik yang berbeda-beda yaitu dengan cara transesterifikasi. Ilustrasi transesterifikasi trigliserida disajikan pada Gambar 6-10.

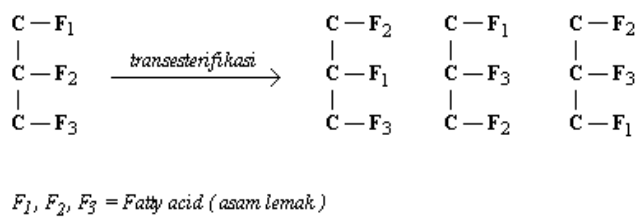

\section{Gambar 6-10: Transesterifikasi trigliserida}

Kebanyakan lemakdan minyak dalam makanan berada dalam fase dispersi atau berbentuk tetes-tetes atau berbentuk globulaglobula. Stabilisasi dispersi dilakukan oleh bahan pengemulsi misalnya protein, fosfolipida, digliserida, monogliserida.

\subsubsection{HIDROLISA}

Gliserida mudah dipecah menjadi asam lemak dan gliserol melalui pemanasan dalam suasana alkalis. Garam basa yang 
dihasilkan oleh asam lemak berupa sabun, sehingga prosesnya disebut penyabunan. Penyabunan yaitu pemecahan lemak secara hidrolitis dan hidrolisa ini akan berlanjut sampai semua ester terhidrolisa.

Deesterifikasi trigliserida juga dikatalisis oleh enzim lipase. Enzim ini tersebar pada seluruh jaringan yang mengandung lipida. Lipase dari setiap sumber bersifat spesifik pada ikatan ester tertentu, misalnya lipase pankreas akan menyerang ikatan ester 1 dan 3. Skema deesterifikasi trigliserida diilustrasikan dalam Gambar 6-11 sebagai berikut.

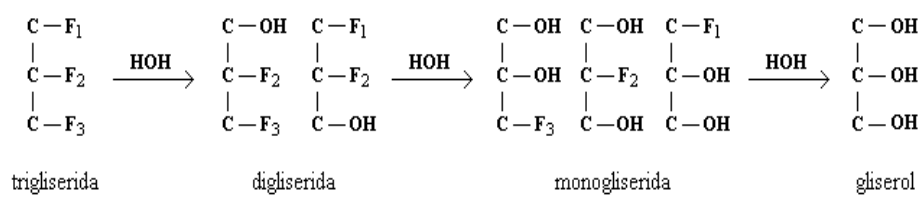

\section{Gambar 6-11: Deesterifikasi trigliserida}

Adanya aktivitas lipase dalam bahan pangan akan menyebabkan timbulnya rasa getir yang merupakan akibat terbebaskannya asam lemak. Asam lemak rantai pendek yang bersifat volatil misalnya asam butirat juga menimbulkan bau yang khas. Kerusakan akibat hidrolisa ini disebut hydrolytic rancidity atau ketengikan akibat hidrolisa. Kerusakan ini sering terjadi pada olive, susu, krim, mentega, dan bangsanya kelapa.

Hasil antara (intermediate product) proses hidrolisa lemak berupa monogliserida dan digliserida yang dapat digunakan sebagai reagen atau bahan pengemulsi atau emulsifier. Monogliserida dan digliserida ini tidak diperoleh dari saponifikasi parsiil dari asam lemak tetapi melalui esterifikasi parsiil antara 
gliserol dengan asam lemak. Monogliserida dan digliserida sangat baik digunakan untuk menstabilkan emulsi, misalnya emulsi pada margarin, salad-dressing, mentega, kopi-krim dan sebagainya.

\subsubsection{OKSIDASI}

Terbentuknya off-flavor pada lemak pangan umumnya disebabkan oleh peristiwa rancidity atau ketengikan. Penyebab ketengikan makanan ini adalah reaksi autooksidasi komponen lipida. Autooksidasi adalah oksidasi nonenzimatis spontan dari substansi lipida yang kontak dengan udara. Kerusakan rancidity ini kadang-kadang diikuti dengan perubahan tekstur sebagai akibat terjadinya reaksi antara produk oksidasi lemak dengan protein.

Oxydative rancidity merupakan jenis lemak pangan yang paling banyak dijumpai, khususnya bahan pangan yang mengandung komponen-komponen trigliserida tidak jenuh. Kerusakan oksidatif ini berakibat rusaknya vitamin-vitamin antara lain vitamin $A, D, E, K, C$, rusaknya asam lemak esensiil, dan timbulnya off falvor yang sangat tajam.

Asam-asam polietanoat lebih mudah mengalami autooksidasi seperti disajikan pada Cambar 6-12. Mekanisme reaksi autooksidasi secara garis besar dapat dikelompokkan menjadi tiga tipe tahapan reaksi, yaitu tahap inisiasi, propagasi, dan terminasi. 
TAHAP I: INISIASI

RH

ahtivasi

$\mathbf{R}^{*}+\mathrm{H}^{*}$

$\mathrm{R}-\mathrm{CH}=\mathrm{C} \cdot \mathbf{H}-\mathrm{H}_{2} \mathrm{C}-\mathrm{CH}=\mathrm{CH}-\mathbf{R}^{\prime}$

$\mathrm{R}-\mathrm{CH}=\mathrm{CH}-\mathrm{HC}^{*}-\mathrm{CH}=\mathrm{C} \cdot \mathrm{H}-\mathrm{R}^{*}+\mathrm{H}^{*}$

asam !emak ndok jemuh

(mual lemeleat)

radkal bebas

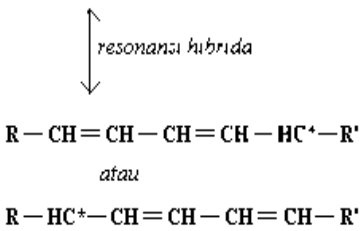

TAHAP II: PROPAGASI

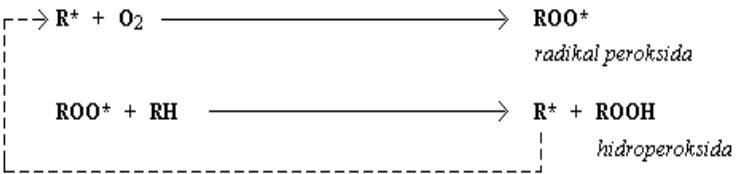
$\mathrm{ROOH}$
$\mathbf{R O}^{*}+\mathrm{OH}^{*} \quad\left(\right.$ juga $\left.\mathbf{R}^{*}, \mathbf{R} 00^{*}, \mathrm{dsb}.\right)$
alkoksi hidroksi
$\mathrm{R}-\mathrm{CH}=\mathrm{CH}-\mathrm{CH}=\mathrm{CH}-\mathrm{HC}^{*}-\mathrm{R}^{\prime}$
$\mathrm{R}-\mathrm{CH}=\mathrm{CH}-\mathrm{CH}=\mathrm{CH}-\mathrm{HCOO}^{*}-\mathrm{R}^{\prime}$
atau
$+\mathrm{O}_{2}$
atau
$\mathrm{R}-\mathrm{HC}^{*}-\mathrm{CH}=\mathrm{CH}-\mathrm{CH}=\mathrm{CH}-\mathrm{R}^{\prime}$
$\mathrm{R}-\mathrm{HCOO}^{*}-\mathrm{CH}=\mathrm{CH}-\mathrm{CH}=\mathrm{CH}-\mathrm{R}^{\prime}$ radikal hidroperoksi
$\mathrm{R}-\mathrm{CH}=\mathrm{CH}-\mathrm{CH}=\mathrm{CH}-\mathrm{HCOO}^{*}-\mathrm{R}^{\prime}$
$\mathrm{R}-\mathrm{CH}=\mathrm{CH}-\mathrm{CH}=\mathrm{CH}-\mathrm{HCOOH}-\mathbf{R}^{\prime}$
atau
$+\mathrm{H}^{+} \longrightarrow$ atau
$\mathrm{R}-\mathrm{HCOO}^{*}-\mathrm{CH}=\mathrm{CH}-\mathrm{CH}=\mathrm{CH}-\mathrm{R}^{\prime}$
$\mathrm{R}-\mathrm{HCOOH}-\mathrm{CH}=\mathrm{CH}-\mathrm{CH}=\mathrm{CH}-\mathrm{R}^{\prime}$
produk hidroperolsida

TAHAP 1]l: TERMINASI

$\mathrm{RCOO}^{+}+x \longrightarrow$ senyawa stabil

Gambar 6-12: Mekanisme reaksi autooksidasi 
Pada tahap inisiasi, beberapa molekul lipida (RH) cukup teraktivasi oleh panas, cahaya, atau katalisator logam dan sebagainya. Kemudian $\mathrm{RH}$ akan terdekomposisi menjadi radikal bebas $\mathrm{R}^{*}$ dan $\mathrm{H}^{*}$. Tidak semua ujung lipida mudah teraktivasi, hanya pada gugus metilenyang berdekatan dengan ikatan rangkap dari asam lemak bersifat labil. Radikal bebas yang terbentuk akan mengalami resonansi hibida membentuk radikal bebas turunan. Radikal bebas yang terbentuk akan cepat hilang melalui proses rekombinasi menjadi $\mathrm{RH}, \mathrm{RR}, \mathrm{H}_{2}, \mathrm{H}_{2} \mathrm{O}$, dan sebagainya.

Pada tahap propagasi, karena adanya oksigen maka radikal bebas $\left(R^{*}\right)$ tidak melakukan rekombinasi, tetapi dengan hadirnya molekul oksigen mungkin akan terjadi pertemuan antara radikal bebas $\mathrm{R}^{*}$ dengan $\mathrm{O}_{2}$ yang akan menghasilkan radikal peroksida (ROO*). Radikal peroksida ini (ROO*) akan bereaksi dengan molekul lipida lainnya $(\mathrm{RH})$ menghasilkan hidroperoksida $(\mathrm{ROOH})$ dan radikal bebas $R^{*}$. Sekarang radikal bebas secara kontinyu akan terbentuk tanpa bantuan aktivator lagi.

Sebenarnya hidroperoksida bukan senyawa volatil, tidak berbau, dan tidak berasa, tetapi dengan terakumulasinya senyawa tersebut akan memacu terjadinya autooksidasi. Hidroperoksida relatif tidak stabil. Naiknya konsentrasi hidroperoksida dalam sistem, mereka akan mengalami dekomposisi. Reaksi dekomposisi monomolekuler dari hidroperoksida akan menghasilkan radikal alkoksi (RO*) dan hidroksi $\left(\mathrm{OH}^{*}\right)$ seperti dibagankan pada Gambar 6-13.

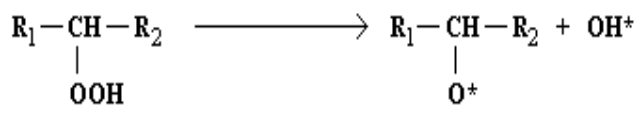

Gambar 6-13: Dekomposisi hidroperoksida 
Lebih lanjut oksidasi bimolekuler antara dua molekul $\mathrm{ROOH}$ akan menghasilkan $\mathrm{H}_{2} \mathrm{O}, \mathrm{ROO}$, RO*. Berbagai kemungkinan reaksi lanjutan dari radikal alkoksi adalah terbentuknya aldehid, alkohol, keton, seperti dibagankan pada Cambar 7-14. Dalam reaksi alkoksi lanjutan akan terbentuk aldehid rantai pendek misalnya peroksida oleat akan menghasilkan aldehid $\mathrm{C}_{8}, \mathrm{C}_{9}, \mathrm{C}_{10}$, $C_{11}$ seperti disajikan pada Gambar 7-14 (1). Apabila radikal alkoksi bereaksi dengan molekul lipida lainnya akan menghasilkan alkohol dan radikal bebas $\mathrm{R}_{3}$ * yang berperan pada propagasi rantai seperti disajikan pada Cambar 7-14 (2). Radikal bebas yang terbentuk dari reduksi alkohol tersebut akan bereaksi dengan radikal alkoksi lainnya membentuk keton seperti pada bagan Gambar 6-14 (3).

(1) Turunan aldehid<smiles></smiles>

(2) Reduksi alkohol:<smiles>[R18]C([R16])[R16]</smiles>

(3) Pembentukan keton<smiles>[Y16][R16]([H])C([R17])[R16]</smiles>

\section{Gambar 6-14: Reaksi lanjutan radikal alkoksi}

Pada tahap terminasi, hidroperoksida melalui reaksi berantai berkelanjutan akan banyak membentuk radikal bebas dan produk akhir yang stabil. Produk akhir ini termasuk senyawa karbonil rantai pendek yang sangat peka untuk membentuk flavor ransid dan reaksi sampingan akan menyebabkan kerusakan lipida. 
Reaksi ini akan berakhir apabila radikal bebas menangkap radikal bebas lainnya atau dengan radikal bebas inaktivator $(x)$, akan menghasilkan senyawa stabil.

\section{a. FAKTOR-FAKTORYANG MEMPENGARUHI OKSIDASI}

Beberapa faktor yang mempengaruhi oksidasi asam lemak pangan antara lain jumlah ikatan tidak jenuh, oksigen, cahaya, suhu, air, dan logam tertentu.

\section{1). JUMLAH IKATAN TIDAKJENUH}

Lemak yang banyak mengandung asam linoleat $\left(\mathrm{C}_{17} \mathrm{H}_{31} \mathrm{COOH}\right)$ lebih mudah teroksidasi daripada yang banyak mengandung asam oleat $\left(\mathrm{C}_{17} \mathrm{H}_{33} \mathrm{COOH}\right)$, dalam jumlah yang sama antara asam linoleat dan asam oleat. Hal ini disebabkan karena asam linoleat mempunyai ikatan rangkap lebih banyak daripada asam oleat. Sebagai gambaran ikatan rangkap pada oleat dan linoleat diilustrasikan pada Cambar 6-15.

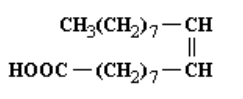

Oleat : cis-9-octadecenoat

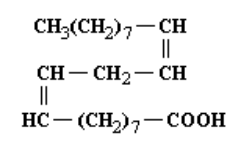

Linoleat : cis-cis-9-12-octadecadienoat

\section{Gambar 6-15: I katan rangkap pada oleat dan linoleat}

\section{2). OKSIGEN}

Kecepatan oksidasi sebanding dengan besarnya tekanan oksigen, sehingga pencegahan oksidasi untuk makanan produk industri dilakukan dengan cara vakum atau hampa udara atau dengan cara memasukkan gas inert misalnya gas nitrogen. 


\section{3). CAHAYA}

Semua bentuk radiasi cahaya dari ultra violet sampai infra merah mempengaruhi oksidasi lemak. Efek sinar ultra violet lebih nyata daripada sinar tampak, karena sinar ultra violet mempunyai energi lebih tinggi. Pengepakan dalam wadah yang kedap cahaya atau wadah berwarna gelap merupakan cara yang umum digunakan untuk menghindari kerusakan oleh cahaya.

\section{4). SUHU}

Suhu mempengaruhi kecepatan autooksidasi, karena kenaikan suhu berkaitan dengan kecepatan reaksi, sehingga cara yang sesuai untuk pencegahan autooksidasi adalah dengan cara penyimpanan pada suhu rendah.

\section{5). AIR}

Air nampaknya mencegah atau menghalangi autooksidasi lemak karena air akan menghalangi absorbsi oksigen.

\section{6). LOGAM TERTENTU}

Beberapa logam tertentu, terutama $\mathrm{Cu}$ dan Fe serta Mn bersifat pro oksidan dalam lemak. Ion logam berat dapat meningkatkan dekomposisi sisi hidroperoksida. Mekanisme reaksinya seperti Cambar 6-16.

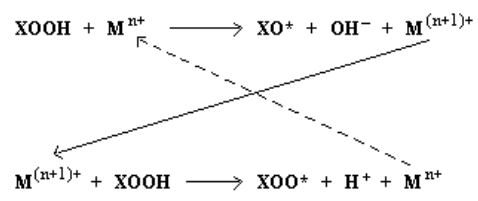

Gambar 6-16: Mekanisme reaksi pengaruh logam 


\section{b. ANTIOKSIDAN}

Antioksidan adalah suatu substansi yang menghambat autooksidasi. Secara teoretis aktivitas antioksidan melalui berbagai jalan, antara lain pengikatan oksigen secara kompetitif, menahan tahap inisiasi, menghalangi tahap propagasi melalui perusakan atau pengikatan radikal bebas, menghindarkan diri dari katalisator ( $\mathrm{Fe}, \mathrm{Cu}, \mathrm{Mn}$ ), stabilisasi hidroperoksida, dan sebagainya.

Di antara berbagai jalan tersebut yang paling penting adalah menghalangi atau blocking tahap propagasi, dimana antioksidan $(\mathrm{AH})$ berfungsi sebagai donor hidrogen $(\mathrm{H})$ terhadap radikal bebas, misalnya ROO* atau R*, mekanismenya seperti dibagankan pada Gambar 6-17.

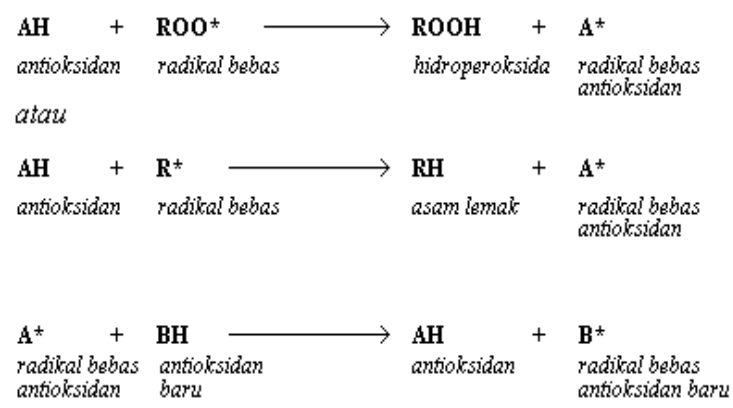

\section{Gambar 6-17: Mekanisme reaksi antioksidan}

Radikal bebas antioksidan ( $\left.A^{*}\right)$ bersifat inaktif, kondisi ini dapat diperbaiki atau diperbarui apabila terdapat donor hidrogen sekunder (BH). Antioksidan dapat dikelompokkan menjadi antioksidan alami dan antioksidan sintetis. Lemak dan minyak terutama apabila belum dimurnikan atau unrefine bersifat 
stabil terhadap oksidasi ketengikan. Stabilitas yang dimiliki ini disebabkan oleh adanya antioksidan alami yang terdapat di dalamnya. Antioksidan alami misalnya $(\alpha, \beta, \gamma)$-tokoferol yang tersebar dalam jaringan hewan atau tanaman. Antioksidan tokoferol efektif untuk lemak hewani tetapi kurang efektif untuk lemak nabati. Tokoferol mudah teroksidasi menjadi tokoquinon yang tidak bersifat antioksidan. Tokoferol juga mudah rusak oleh panas, terutama pada suhu refining dan prosesing lemak serta minyak. Oleh karena itu, seringkali digunakan antioksidan yang lebih stabil. Antioksidan yang banyak digunakan adalah Butylated Hydroxy Abisole (BHA), Butylated Hydroxy Toluene (BHT), Propyl Callate (PG), dan asam sitrat.

\section{c. EFEK AUTOOKSIDASI}

\section{1). FLAVOR}

Efek autooksidasi antara lain timbulnya odor dan flavor yang tidak disukai. Secara kimiawi ketengikan merupakan akibat dekomposisi peroksida yang menghasilkan karbonil rantai pendek. Timbulnya bau anyir dari minyak nabati disebabkan terjadinya reversi flavor yaitu apabila minyak disimpan pada suhu tinggi dan berhubungan dengan udara.

\section{2). WARNA}

Oksidasi lipida tidak mempunyai akibat langsung terhadap bahan makanan. Radikal bebas yang dihasilkan selama tahap propagasi dari oksidasi lipida, merupakan penyebab rusaknya pigmen karotenoid yang terdapat dalam bahan makanan secara oksidatif. 
Di samping itu juga terjadi reaksi pencoklatan Maillard, yaitu reaksi antara protein dengan karbonil hasil pemecahan oksidasi lipida, inilah yang menyebabkan warna hasil gorengan menjadi kekuningan.

\section{3). TEKSTUR}

Protein mempunyai kecenderungan untuk membentuk radikal bebas. Atom $\mathrm{H}$ yang dilepaskan oleh protein akan diterima oleh radikal bebas lemak. Protein dan radikal bebas lemak tersebut cenderung saling berikatan melalui ikatan silang atau cross linkage. Agregasi inilah yang menyebabkan teksturnya menjadi keras.

\subsection{WAXES}

Waxes atau lilin lipida adalah jenis lipida yang merupakan ester antara asam lemak dengan alkohol monohidrat berberat molekul besar yang mempunyai rantai atom C antara 29 sampai 36.

Waxes yang terdapat di alam mengandung parafin, asam lemak tidak jenuh, alkohol sekunder, keton dan hidrokarbon yang mempunyai jumlah atom $\mathrm{C}$ ganjil. Waxes bersifat lebih tahan terhadap hidrolisa daripada lemak, mempunyai titik cair $(60-80)^{\circ} \mathrm{C}$, tahan terhadap saponifikasi daripada lemak dan minyak, juga kurang mudah mengalami autooksidasi. Pada hewan waxes menutupi permukaan rambut, wool, dan bulu. Pada tanaman waxes menutupi permukaan tangkai, daun, dan buah. Waxes buah- buahan sering mengandung senyawa siklis jenis triterpenoid misalnya asam ursolat berupa lapisan putih yang menutupi permukaan buah anggur, apel, dan sebagainya. 


\subsection{FOSFOLIPIDA}

Fosfolipida adalah lipida yang mengandung radikal bebas asam fosfat. Umumnya fosfolipida berupa digliserida yang mengandung asam fosfat dan basa nitrogen berupa kolin (fosfatidilkolin), etanolamin (fosfatidiletanolamin), atau serin (fosfatidilserin). Sebagai gambaran rumus strukturnya diilustrasikan pada Gambar 6-18.

(1) Fosfatidilkolin

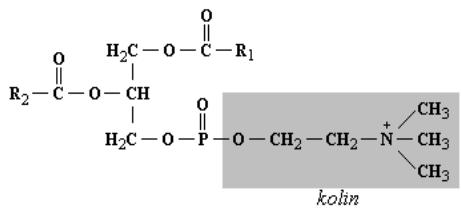

(3) Fosfatidilserin

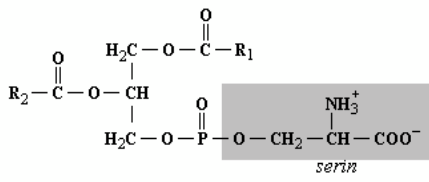

(2) Fosfatidiletanolamin

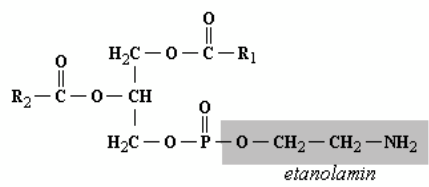

Gambar 6-18: Rumus struktur fosfat dengan (kolin, etanolamin, serin)

Fosfolipida dijumpai pada hampir semua lemak tumbuhan dan binatang. Dalam minyak nabati terdapat sekitar (1-2)\% fosfolipida, sedangkan dalam lemak hewani kadarnya lebih tinggi misalnya kuning telur mengandung sekitar 20\% fosfolipida. Untuk lemak dan minyak yang telah mengalami refining kadarnya sangat rendah, karena fosfolipida akan hilang selama proses refining.

Fosfolipida mempunyai fungsi biologi yang penting antara lain: (1) sebagai elemen struktur dalam sel hidup, (2) sebagai perantara transport, absorbsi, dan metabolisme asam lemak, 
(3) sebagai penyimpanan asam lemak dan fosfat, (4) sebagai komponen penting dalam oksidasi biologi, (5) sebagai perantara penggunaan ion sodium atau $\mathrm{Na}^{+}$dan ion potasium atau $\mathrm{K}^{+}$, (6) dibutuhkan dalam pembekuan darah.

Fosfolipida meliputi fosfogliserida (lesitin, sefalin, plasmalogen), sfingolipid (sfingomielin), dan fosfoinositida.

\subsubsection{LESITIN}

Lesitin terdapat dalam jaringan syaraf, kuning telur, hati, kedele, dan beberapa minyak nabati. Fungsinya dalam jaringan adalah untuk menjaga molekul nonpolar seperti sterol tetap dalam keadaan emulsi. Lesitin secara komersiil digunakan sebagai emulsifier dan antioksidan dalam pengolahan makanan.

Lesitin mengandung gliserol dan asam lemak, seperti halnya lemak sederhana tetapi ia juga mengandung asam fosfat dan kolin. Sebagai ilustrasi disajikan pada Gambar 6-19. Lesitin mempunyai ciri seperti lilin, padat, tidak berwarna, apabila terkena cahaya warnanya berubah menjadi kuning kemudian coklat.

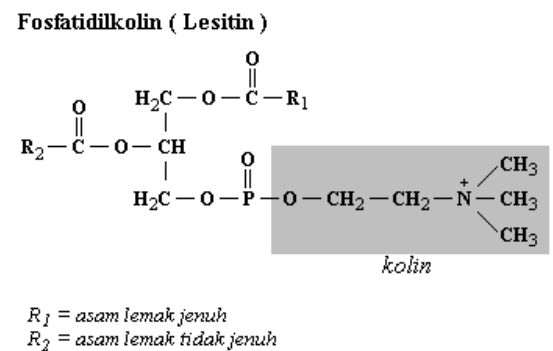

\section{Gambar 6-19: Lesitin ( Fosfatidilkolin )}


Asam lemak yang terikat pada posisi a atau $\mathrm{C}_{1}$ adalah asam lemak jenuh $\left(\mathrm{R}_{1}\right)$ misalnya asam palmitat atau asam stearat. Asam lemak yang terikat pada posisi $b$ atau $C_{2}$ adalah asam lemak tidak jenuh $\left(R_{2}\right)$ misalnya asam oleat, asam linoleat, asam linolenat, asam arakhidonat.

Lesitin bersifat amfoter atau dipolar yaitu pada ujung nitrogen bermuatan positif (+) dan ujung fosfor bermuatan negatif $(-)$, pada $\mathrm{pH}=7$ akan membentuk zwitter-ion.

\subsubsection{SEFALIN}

Sefalin atau fosfatidiletanolamin perbedaannya dengan lesitin adalah hanya pada penggantian kolin (dalam lesitin) digantikan dengan etanolamin. Sebagai ilustrasi disajikan pada Gambar 6-20. Sefalin lebih banyak mengandung ikatan rangkap dibandingkan dengan lesitin. Asam lemak yang terikat pada ujung $\mathrm{C}_{2}$ hanya asam stearat jenuh.

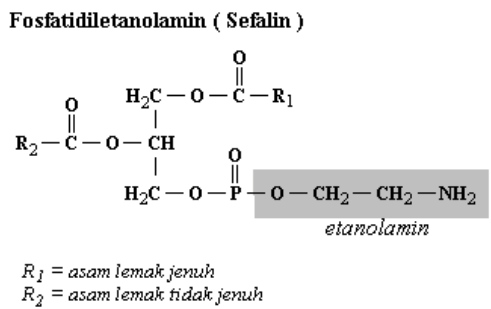

\section{Gambar 6-20: Sefalin ( Fosfatidiletanolamin )}

Sefalin tidak berwarna yang dengan mudah akan terbentuk warna kegelapan sampai coklat kemerahan apabila berhubungan dengan udara dan terkena cahaya. Sefalin dapat diisolasi dari otak, hati, dan khamir. Sefalin bersifat larut dalam kebanyakan pelarut lemak tetapi tidak larut dalam alkohol. 


\subsubsection{PLASMALOGEN}

Perbedaannya dengan lesitin dan sefalin adalah asam lemak pada posisi a atau $C_{1}$ digantikan dengan eter tidak jenuh. Sebagai ilustrasi disajikan pada Gambar 6-21. Plasmalogen terdapat pada membran jaringan otot, otak, dan jantung.

$$
\begin{aligned}
& \text { Plasmalogen ( Fosfatidiletanolamin ) }
\end{aligned}
$$

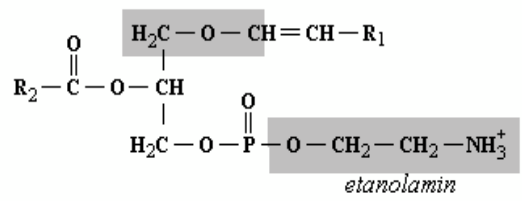

\section{Gambar 6-21: Plasmalogen}

\subsection{STEROL (STEROID)}

Steroid sering ditemukan bersama-sama dengan lemak. Steroid dapat dipisahkan dari lemak setelah proses saponifikasi karena ia tidak dapat disabunkan. Sterol adalah alkohol berberat molekul besar, tidak dapat disaponifikasi, tidak larut dalam air, sedikit larut dalam alkohol dingin atau petroleum ether, mudah larut dalam lemak dan pelarut lemak pada umumnya.

KerangkaCdaristeroladalahintisiklopentanoperhidrofenantren. Sterol terdapat dalam lemak nabati dan hewani. Sterol yang berasal dari nabati disebut fitosterol atau ergosterol, sedangkan yang berasal dari hewani disebutzoosterolatau kolesterol. Adapun yang berasal dari tumbuhan tingkat rendah seperti fungi atau jamur disebut mycosterol. Kolesterol tersebar luas dalam semua sel tubuh, terutama dalam jaringan syaraf. Ergosterol terdapat dalam tumbuh-tumbuhan dan ragi. Ergosterol penting sebagai prekursor vitamin D.] 


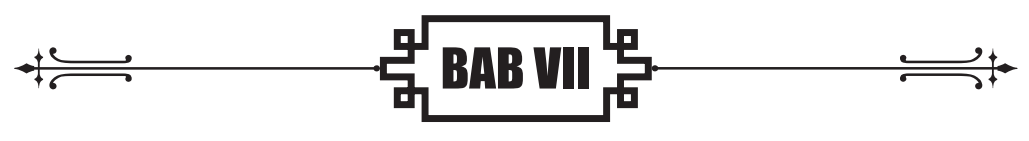

\section{REAKSI PENCOKLLTHN}

Pembentukan warna gelap dalam makanan selama proses pengolahan dan selama penyimpanan merupakan gejala yang sangat umum. Masalah ini menjadi perhatian utama karena tidak hanya menyangkut warna dan kenampakan, tetapi juga aroma dan nilai nutrisi.

Reaksi pencoklatan adalah suatu reaksi kompleks yang terjadi jika bahan makanan mengalami proses pengolahan atau dikenai suatu perlakuan. Proses pencoklatan yang terjadi pada bahan makanan selama pengolahan dan penyimpanan tidak selalu merupakan proses yang tidak dikehendaki, kadangkadang justru diinginkan. Beberapa contoh proses pencoklatan yang dikehendaki misalnya penggorengan kopi, penggorengan kacang, pengolahan daun teh, dan lain-lain. Pencoklatan yang tidak dikehendaki misalnya pengeringan sayuran dan buahbuahan, pembuatan sari buah dan sebagainya.

Berdasarkan proses terjadinya, pencoklatan dapat dikelompokkan menjadi pencoklatan ensimatis dan pencoklatan nonensimatis. Pencoklatan ensimatis adalah proses pencoklatan 
yang terjadinya dikatalisis oleh ensim. Sedangkan pencoklatan nonensimatis adalah pencoklatan yang umumnya terjadi selama penyimpanan atau dalam proses pengolahan.

\subsection{PENCOKLATAN NON ENSIMATIS}

Dalam pembentukan warna coklat diperkirakan terdapat tiga mekanisme reaksi pencoklatan yang berbeda-beda. Ketiga mekanisme tersebut yaitu, reaksi Maillard, oksidasi asam askorbat, dan karamelisasi. Reaksi Maillard tidak memerlukan oksigen dari udara, tetapi harus tersedia senyawa amino untuk memulai reaksi, dan reaksi lebih mudah terjadi dalam suasana alkalis. Oksidasi asam askorbat dapat terjadi langsung oleh adanya oksigen dari udara atau oleh bantuan ensim askorbat oksidase, dan reaksi lebih mudah terjadi dalam suasana asam. Karamelisasi tidak memerlukan oksigen dari udara dan gugus amino, tetapi memerlukan suhu tinggi dalam waktu cukup lama, dan reaksi dapat terjadi baik dalam suasana asam atau alkalis. Bahan makanan merupakan suatu sistem yang kompleks, maka peristiwa yang terjadi adalah kombinasi atau interaksi dari ketiga jalan reaksi tersebut.

Komponen bahan pangan yang paling berperan dalam reaksi pencoklatan nonensimatis adalah karbohidrat berberat molekul rendah dan derivatnya seperti gula, asam gula, asam askorbat. Asam-asam amino bebas dan gugus amino bebas dari protein dan peptida berperan dalam pembentukan pigmen coklat. Meskipun demikian, pencoklatan juga dapat terjadi tanpa adanya substansi nitrogen tersebut. 


\subsubsection{REAKSI MAILLARD}

Senyawa karbonil atau polikarbonil sangat penting dalam reaksi pencoklatan tahap awal dari reaksi pencoklatan perubahan senyawa karbonil. Apabila bahan makanan yang telah melalui proses ekstraksi dan senyawa karbonil yang ada dihilangkan, maka pencoklatan dapat ditiadakan atau dikurangi.

Maillard, seorang ahli kimia bangsa Prancis merupakan orang yang pertama kali mempelajari kondensasi antara gula dan asam amino. Pada tahun 1912 ia melaporkan bahwa apabila campuran asam amino dan gula dipanaskan akan membentuk warna coklat. Semenjak itulah reaksi Maillard dijadikan panutan pada percobaan-percobaan berikutnya tentang proses pencoklatan nonensimatis dalam bahan makanan. Tahapan reaksi Maillard melalui lima tahapan, yaitu kondensasi karbonil amino, perubahan Amadori, pembentukan pigmen, degradasi Strecker, dan polimerisasi.

\section{a. KONDENSASI KARBONILAMINO}

Pada tahap ini terjadi reaksi antara gugus karbonil, baik aldehid maupun keton yang berasal dari gula reduksi, misalnya glukosa dengan gugus amino yang berasal dari asam amino, peptida, protein baik protein primer maupun protein sekunder misalnya asam amino glisin. Apabila reaktannya berupa senyawa amin dan aldosa misal glukosa, maka hasil reaksinya yaitu aldosamin (dari glukosa akan terbentuk glikosilamin). Sebelum terbentuk glikosilamin, lebih dahulu terbentuk basa Schiff, kemudian segera berubah menjadi glikosilamin dan reaksi ini disebut reaksi karbonil amino. Mekanismenya seperti disajikan 
pada Cambar 7-1. Senyawa hasil reaksi ini masih tetap tidak berwarna. Aktivitas kedua reaktan tersebut satu sama lain tergantung pada baik tipe gula maupun tipe asam maino. Pentosa lebih reaktifdaripada heksosa, aldosa pada umumnya lebih rekatif daripada ketosa, monosakarida lebih rekatif daripada disakarida.

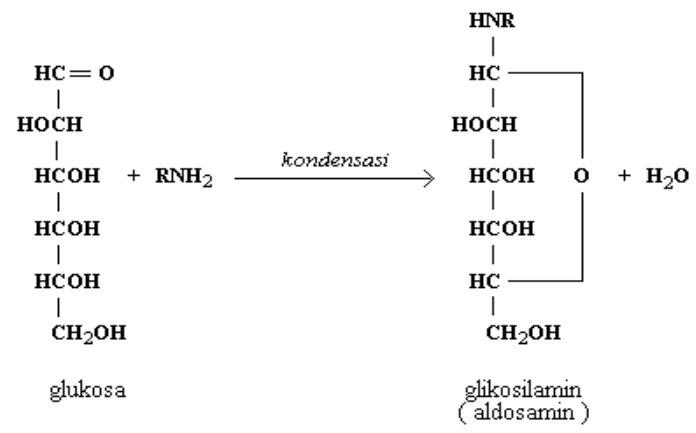

\section{Gambar 7-1: Reaksi karbonil-amino}

Reaksi kondensasi sendiri sifatnya reversibel dan senyawa glikosilamino mudah terhidrolisa oleh larutan asam. Adanya gugus $\mathrm{NH}_{2}$ dari amin, asam amino atau protein akan menghambat reaksi kondensasi karena senyawa tersebut akan menurunkan $\mathrm{pH}$. Oleh karena itu, diharapkan untuk menaikkan kecepatan reaksi kondensasi diperlukan $\mathrm{pH}$ tinggi atau $\mathrm{pH}$ alkalis.

\section{b. AMADORI REARRANGEMENT}

Clikosil amin mengalami perubahan atau rearrangement menjadi fruktosamin atau 1-amino 1-deoksi fruktosa. Perubahan dari aldosamin (dalam contoh ini glikosilamin) menjadi ketosamin (dalam contoh fruktosamin) disebut Amadori rearrangement atau perubahan Amadori. Mekanisme reaksinya seperti disajikan pada Cambar 7-2. 


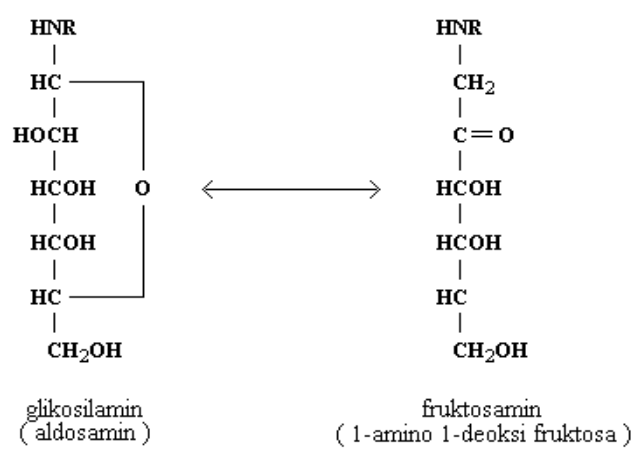

Gambar 7-2: Perubahan Amadori

\section{c. DEHIDRASI KETOSAMIN}

Dehidrasi ketosamin merupakan tahap pembentukan pigmen. Pada tahapan ini hasil-hasil perubahan Amadori mengalami perubahan lebih lanjut melalui berbagai jalan dalam pembentukan pigmen warna, yaitu melalui jalan media asam atau netral dan melalui jalan media kering atau melalui redukton.

\section{1). MELALUI MEDIA ASAM ATAU NETRAL}

Ketosamin misalnya fruktosamin merupakan produk dari perubahan Amadori. Pertama-tama fruktosamin mengalami isomerisasi menjadi bentuk enol, reaksi ini bersifat reversibel. Sekarang gugus $-\mathrm{OH}$ pada $\mathrm{C}_{3}$ tereliminasi membentuk basa Schiff. Selanjutnya basa Schiff mengalami hidrolisa menghasilkan 3-deoksi osulosa sebagai suatu enol. Kemudian senyawa tersebut mengalami eliminasi hidroksil pada $\mathrm{C}_{4}$ melalui hidrolisa menghasilkan osulosa tidak jenuh. Osulosa tersebut akan mengalami transformasi 
membentuk Hydorxy Methyl Furfural (HMF) dengan jalan mengeluarkan molekul air. Mekanisme dehidrasi ketosamin atau pembentukan pigmen ini disajikan pada Gambar 7-3.

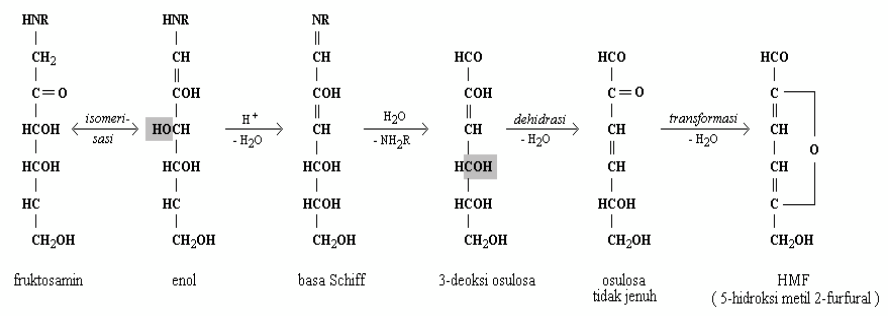

\section{Gambar 7-3: Perubahan Amadori (dehidrasi ketosamin )}

Eliminasi gugus nitrogen dari basa Schiffitu tidak penting apabila gugus nitrogen masih tetap berada dalam molekul, maka yang dihasilkan bukan HMF, tetapi basa-Schiff- HMF. Mekanismenya seperti disajikan pada Gambar 7-4, yang hanya digambarkan senyawa awal dan produk akhirnya saja, sedangkan senyawa intermediernya tidak digambarkan.

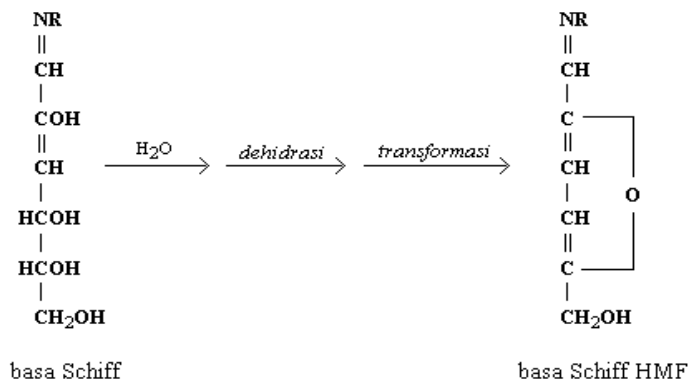

Gambar 7-4: Basa Schiff HMF

Dengan terakumulasinya HMF segera akan terbentuk pigmen berwarna gelap. Oleh karena itu, dengan menentukan 
jumlah HMF menggunakan spektrofotometer dapat digunakan untuk memprediksi kecepatan pencoklatan suatu bahan pangan yang disimpan atau diolah.

\section{2). MELALUI MEDIA KERING}

Mekanisme melalui media kering ini dengan senyawa intermedier berupa redukton yang rumusnya $\mathrm{R}_{1}-\mathrm{COH}=\mathrm{COH}$ CO-R, pembentukan senyawa redukton disajikan pada Gambar 7-5.

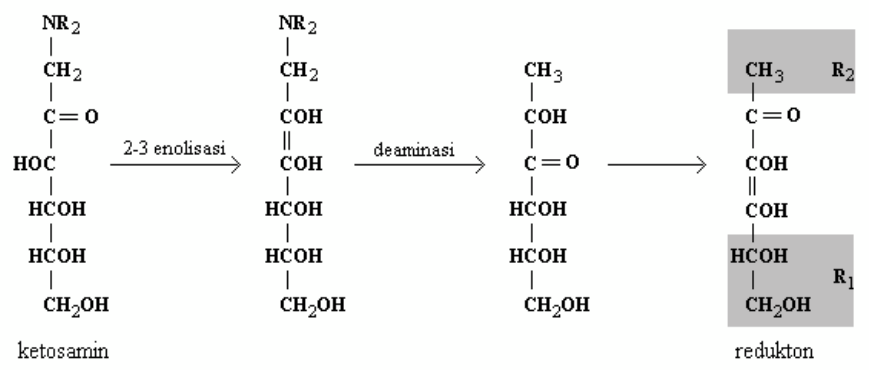

Gambar 7-5: Pembentukan redukton

Redukton mempunyai daya mereduksi sangat tinggi atau sangat kuat. Redukton mengalami dehidrasi, kondensasi dengan amin dan akhirnya terjadi polimerisasi membentuk melanoidin. Di samping itu juga terbentuk senyawa berberat molekul lebih kecil seperti diasetil, asam asetat, piruvaldehid, dan sebagainya.

\section{d. DEHIDRASISTRECKER}

Adanya senyawa dikarbonil tertentu, maka asam amino akan mengalami dekarboksilasi dan deaminasi asam amino menjadi aldehid, reaksi ini disebut degradasi Strecker. Pada tahap ini 
terjadi degradasi dan pemecahan. Aldehid yang terbentuk (yang berasal dari asam amino) jumlah atom C-nya berkurang sebuah dan terlepas sebagai $\mathrm{CO}_{2}$, mekanismenya disajikan pada Gambar 7-6.

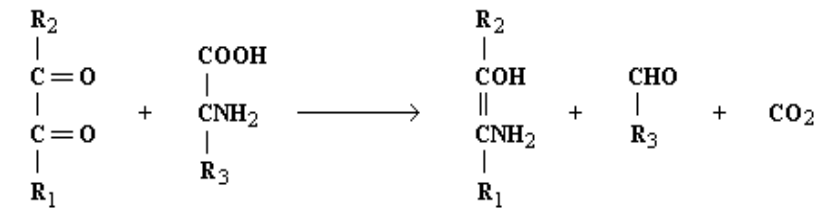

dikarbonil amino aldehid

\section{Gambar 7-6: Degradasi Strecker}

Terbentuknya aldehid dalam reaksi ini dapat menyebabkan terjadinya flavor tertentu sebagai akibat tercampurnya beberapa macam senyawa. Aroma yang terbentuk dalam campuran asam amino dan glukosa seperti disajikan pada Tabel 7-1.

\section{Tabel 7-1: Aroma campuran asam amino dan glukosa}

\begin{tabular}{|c|c|c|c|}
\hline \multirow{2}{*}{ No. } & \multirow{2}{*}{$\begin{array}{c}\text { Jenis asam amino yang } \\
\text { dicampur dengan glukosa }\end{array}$} & \multicolumn{2}{|c|}{ Aroma yang timbul pada pemanasan } \\
\hline & & $100^{\circ} \mathrm{C}$ & $180^{\circ} \mathrm{C}$ \\
\hline 1. & tanpa asam amino & - & karamel \\
\hline 2. & asam amino valin & seperti roti & seperti coklat \\
\hline 3. & asam amino leusin & $\begin{array}{l}\text { seperti kembang gula } \\
\text { coklat }\end{array}$ & seperti keju terbakar \\
\hline 4. & asam amino prolin & seperti protein terbakar & sedap \\
\hline 5 & asam amino glutamin & seperti coklat & seperti mentega \\
\hline 6. & asam amino aspartat & seperti rock candy & seperti karamel \\
\hline 7. & asam amino lisin & - & seperti roti \\
\hline
\end{tabular}




\section{e. POLIMERISASI}

Senyawa intermedier seperti furfural dan derivatnya, deoksi osula dan osulosa tidak jenuh, aldehid dari degradasi Strecker, aldehid dan keton dari pemecahan gula dan sebagainya merupakan senyawa yang reaktif. Kemudian akan terjadi polimerisasi membentuk senyawa kompleks berberat molekul tinggi berwarna coklat yang disebut melanoidin. Senyawa melanoidin bersifat larut dalam air dan senyawa ini belum diketahui strukturnya.

\subsubsection{OKSIDASI ASAM ASKORBAT}

Dalam industri saribuah, proses pencoklatan yang disebabkan oleh oksidasi asam askorbat merupakan proses yang penting. Suatu larutan model yang terdiri dari asam askorbat dan asam amino ternyata lebih cepat berubah warna menjadi gelap daripada larutan model yang terdiri dari gula dan asam amino dalam kondisi yang sama. Pencoklatan juga terjadi dalam larutan asam askorbat murni terutama pada $\mathrm{pH}$ tinggi.

Dekomposisi asam askorbat terjadi oleh adanya udara atau di bawah kondisi oksidatif, dimulai dari terbentuknya dehidro asam askorbat. Kemudian akan mengalami transformasi menghasilkan asam 2,3-diketo-gulonat. Selanjutnya asam 2,3-diketo gulonat mengalami dekomposisi membentuk furfural sebagai suatu senyawa intermedier. Mekanismenya disajikan pada Gambar 7-6. 


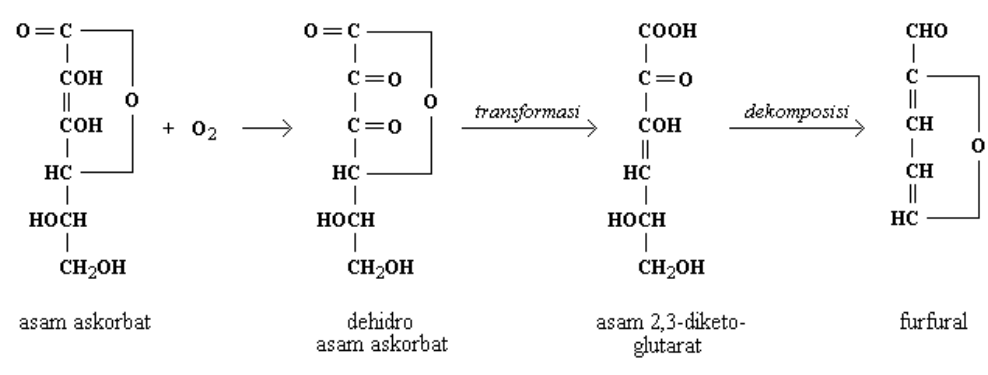

Cambar 7-6: Oksidasi asam askorbat

Asam askorbat adalah suatu redukton, maka ia dapat langsung masuk ke dalam tahapan polimerisasi dengan amin menghasilkan pigmen coklat. Tetapi pada tahap awalnya asam askorbat harus mengalami dekomposisi.

\subsubsection{KARAMELISASI}

Pada kenyataannya, gula dapat mengalami proses pencoklatan tanpa adanya senyawa amino, tetapi memerlukan suhu sangat tinggi. Gula murni dapat mengalami karamelisasi dengan cepat pada suhu di atas $100^{\circ} \mathrm{C}$, dan beberapa senyawa bukan amino mempunyai aktivitas katalisator. Senyawa itu adalah berupa garam dari asam karboksilat (sitrat, fumarat, tartrat, malat) dengan fosfat, alkali, asam. Secara pasti mekanisme karamelisasi belum diketahui. Untuk itu, digunakan asumsi bahwa mekanismenya sama dengan pencoklatan gula-amino, melalui enolisasi, dehidrasi dan pemecahan. Mekanisme reaksi karamelisasi salah satu di antaranya diajukan oleh Wolform yang disajikan pada Gambar 7-7, dengan hasil akhir berupa HMF. 


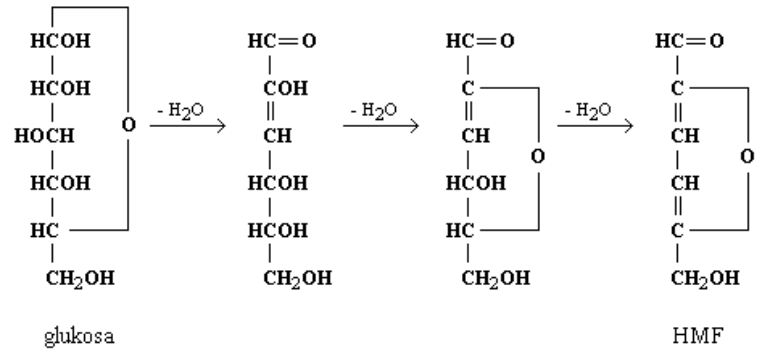

Gambar 7-7: Mekanisme karamelisasi Wolform

\subsubsection{EFEK FAKTOR LINGKUNGAN}

Kecepatan pencoklatan nonensimatis sangat tergantung kondisi lingkungan seperti suhu, $\mathrm{pH}$, kadar air, adanya faktor pemacu, dan penghambat.

\section{a. KONDISI LINGKUNGAN}

Faktor pemacu proses pencoklatan nonensimatis yang paling banyak berpengaruh antara lain suhu, $\mathrm{pH}$, kandungan air, oksigen.

\section{1). SUHU}

Energi aktivasi pada akumulasi HMF, interaksi gulaamino dan pembentukan pigmen sangat dipengaruhi oleh suhu. Pada prinsipnya, semakin tinggi suhu maka terjadinya perubahan warna coklat menjadi semakin cepat.

2). $\mathrm{PH}$

Pengaruh $\mathrm{pH}$ terhadap kecepatan reaksi pencoklatan sangat kompleks. Untuk itu dapat digunakan patokan bahwa kondensasi gula-amino lebih baik terjadi pada 
media dengan $\mathrm{pH}$ tinggi atau media yang alkali. Kenyataannya dalam medium selama terjadi proses pencoklatan juga mengalami perubahan $\mathrm{pH}$. Oleh karena itu, ada kaitannya dengan larutan buffer. Dalam larutan buffer yang terdiri dari garam alkali dari asam karboksilat atau fosfatakan berfungsi sebagai katalisator, misalnya Na-fosfat, sehingga akan mempercepat reaksi pencoklatan.

\section{3). KANDUNGAN AIR}

Kecepatan reaksi pencoklatan menurun sejalan dengan menurunnya kandungan air dalam bahan pangan. Reaksi pencoklatan mempunyai kadar air optimum agar reaksi berjalan dengan baik, contoh yang pernah dicoba oleh Lea dan Haunan didapatkan bahwa kaseinglukosa mengalami reaksi pencoklatan paling baik pada kandungan air 13 persen.

\section{4). OKSIGEN}

Pada sebagian tipe reaksi pencoklatan berkaitan langsung dengan oksigen, misalnya reaksi oksidasi asam askorbat. Sedangkan reaksi Maillard tidak memerlukan oksigen.

\section{5). FAKTOR PEMACU}

Garam-garam dari fosfat dan asam karboksilat mempunyai kaitan dengan pencoklatan nonensimatis dan naiknya intensitas warna. Efek logam terhadap pencoklatan antara satu jenis dengan jenis lainnya tidak sama. Tembaga (Cu) menaikkan reaksi 
pencoklatan pada asam askorbat terkait dengan oksidasi substansi itu di bawah cahaya.

Sedangkan besi (Fe) dan tembaga $(\mathrm{Cu})$ pada reaksi Maillard sejauh yang diketahui mempunyai efek sebaliknya. Timah (Sn) tampaknya memperlambat reaksi pencoklatan nonensimatis, misalnya produk jeruk dalam kemasan kaleng atau gelas berwarna coklat lebih mudah mengalami reaksi pencoklatan daripada dalam kaleng berlapis timah. Efek penghambatan timah ini efeknya lebih baik dalam media $\mathrm{pH}$ rendah.

\section{b. FAKTOR PENGHAMBAT}

Perlakuan yang dapat dilakukan untuk mencegah atau menghambat proses pencoklatan nonensimatis antara lain suhu, kandungan air, derajat keasaman, pembungkusan dengan gas inert, penggunaan ensim, dan penggunaan zat kimia.

\section{1). SUHU}

Penyimpanan pada suhu rendah dapat mengurangi proses pencoklatan karena secara umum penurunan suhu akan memperlambat reaksi kimia. Oleh karena itu, penyimpanan makanan dalam suhu dingin misalnya dalam almari pendingin dapat menurunkan kecepatan reaksi pencoklatan.

\section{2). KANDUNGANAIR}

Proses pencoklatan memerlukan kandungan air pada tingkat tertentu. Karena itu, dengan cara mengurangi kandungan air dari bahan makanan misalnya dengan 
cara pengeringan akan dapat menghambat proses pencoklatan.

\section{3). $\mathrm{PH}$}

Proses pencoklatan berlangsung lebih baik pada $\mathrm{pH}$ alkalis, maka penurunan $\mathrm{pH}$ merupakan salah satu cara untuk mencegah pencoklatan ensimatis.

\section{4). GAS INERT}

Udara dalam ruang head space dapat mempercepat pencoklatan karena udara mengandung $\mathrm{O}_{2}$. Karena itu, mengeluarkan $\mathrm{O}_{2}$ dan menggantinya dengan gas inert merupakan cara pencegahan yang baik. Hilangnya $\mathrm{O}_{2}$ ini terutama mencegah oksidasi lipida yang menghasilkan aldehid dan keton, dimana senyawa itu dengan amino akan membentuk pigmen coklat.

\section{5). PENGGUNAANENSIM}

Jika bahan makanan sedikit mengandung reaktan yang berperan dalam interaksi gula-amino, maka reaktan tersebut harus dihilangkan atau dibuat tidak aktif. Misalnya untuk menghilangkan glukosa dari putih telur yang akan dikeringkan dengan menggunakan fermentasi yeast. Contoh lain penggunaan glukosa oksidase dan katalase untuk mengkonversi glukosa menjadi asam glukonat yang tidak dapat berinteraksi dengan gugus amino. Mekanisme reaksinya disajikan pada Gambar 7-8. Penggunaan glukosa oksidase mempunyai keuntungan lain, yaitu dapat menghilangkan $\mathrm{O}_{2}$ pada head space. 


$$
\begin{aligned}
& \mathbf{R}-\mathrm{CHO}+\mathrm{O}_{2}+\mathrm{H}_{2} \mathrm{O} \stackrel{\text { glukosa oksidase }}{\longrightarrow} \mathrm{R}-\mathrm{COOH}+\mathrm{H}_{2} \mathbf{O}_{2} \\
& \text { gula } \\
& \text { asam glukonat }
\end{aligned}
$$

$$
\mathrm{H}_{2} \mathrm{O}_{2} \longrightarrow \text { katalase } \longrightarrow \mathrm{H}_{2} \mathbf{O}+1 / \mathrm{i}_{2} \mathrm{O}_{2}
$$

Gambar 7-8: Mekanisme reaksi ensimatis

\section{6). PENGGUNAAN BAHAN KIMIA}

Zat-zat kimia yang dapat menghambat proses pencoklatan dan telah dipakai untuk berbagai bahan makanan antara lain senyawa sulfit, bisulfit, thiol, dan garam kalsium.

\section{a). SULFIT}

Fungsi senyawa sulfit adalah untuk menghambat konversi glukosa menjadi HMF, menghambat konversi asam askorbat menjadi furfural, inaktivasi gugus karbonil dari gula reduksi, menghentikan aktivitas gugus dikarbonil hingga akibatnya mengurangi pembebasan $\mathrm{CO}_{2}$ sebagai hasil degradasi Strecker. Asam belerang menghambat reaksi adisi pada gugus karbonil. Sulfur dioksida memblock gugus karbonil dari gula reduksi sehingga interaksi aldosa-amino terhambat. Mekanismenya seperti disajikan pada Gambar 7-9. Di samping itu, $\mathrm{SO}_{2}$ juga bereaksi secara khusus bersatu dengan substansi karbonil seperti osulosa dan HMF yang terbentuk pada tahap akhir reaksi. 
<smiles>[R2]C([R1])=[O+]SCC</smiles>

Cambar 7-9: Mekanisme blocking gugus karbonil

b). THIOL

Penggunaan thiol dalam bahan makanan ini terbatas karena sifat-sifatnya kurang disukai bagi bahan makanan. Contoh penggunaannya yaitu pada penambahan merkaptoetanol dan merkaptoasetat yang dapatmenghambat pencoklatan pada glukosaglisin. Selain itu, sistein dapat ditambahkan pada telur atau putih telur untuk menghambat reaksi pencoklatan.

\section{c). GARAM KALSIUM}

Penghambatan proses pemcoklatan dengan $\mathrm{CaCl}_{2}$ pernah diujicoba oleh Simon dan Burton pada kentang, meskipun telah diberi sulfit tetap mengalami pencoklatan. Tetapi setelah diberi $\mathrm{CaCl}_{2}$ proses pencoklatannya terhambat.

\subsection{PENCOKLATAN ENSIMATIS}

Pencoklatan ensimatis banyak terjadi pada buah-buahan dan sayuran seperti kentang, apel, pisang, dan sebagainya. Jaringan buah dan sayuran yang terluka apabila berhubungan dengan udara maka jaringan tersebut akan segera menjadi coklat. Kadang-kadang pencoklatan ini dikehendaki misalnya 
pada pengolahan teh dan cacao, tetapi kadang-kadang tidak dikehendaki misalnya pada apel, pisang, dan sebagainya.

Penelitian-penelitian tentang pencoklatan ensimatis antara lain yang telah dilakukan oleh Lindet (1895), Onslow (1920), Joslyn \& Ponting (1951), menyimpulkan suatu asumsi bahwa dasar reaksi ensimatis yaitu reaksi oksidasi terhadap fenol atau polifenol oleh ensim-ensim. Penamaan ensimpenyebaboksidasi fenolatau polifenol oleh ensim-ensim. Penamaan ensim penyebab oksidasi fenol atau polifenol ini belum dibakukan, seringkali hanya disebut fenol oksidase, polifenol oksidase, fenolase, polifenolase. Substrat dari ensim tidak sama untuk setiap buah-buahan atau sayuran, beberapa di antaranya katekol, tirosin, 3,4-dihidro-fenil alanin, asam-asam kafeat, klorogenat, galat, urusinol, hidroksiquinon, antosianin, dan flavonoida.

\subsubsection{MEKANISME}

Terdapat dua tipe reaksi yang sering dijumpai dalam reaksi pencoklatan ensimatis, yaitu hidrolisa dan oksidasi.

\section{a. HIDROLISA}

Hidrolisa atau cresolase activity terjadi pada senyawa fenol yang hanya mengandung satu gugus hidroksil disebut monofenol misalnya tirosin. Reaksi ini akan menghasilkan ortho difenol atau katekol. Pada Cambar 7-10 dicontohkan cresolase activity terhadap tirosin oleh ensim katekolase menghasilkan 3,4-dihidroksifenilalanin (DOPA). Kresolase termasuk ensim transferase artinya ensim ini mempunyai aktivitas mentransfer oksigen ke substrat. Reaksi ini penting pada pencoklatan ensimatis pada jaringan kentang dan biosintesa melanin pada binatang. 
Substrat pada kentang yaitu asam amino tirosin. Pada binatang tirosin merupakan prekursor melanin yaitu pigmen pada rambut dan kulit binatang.

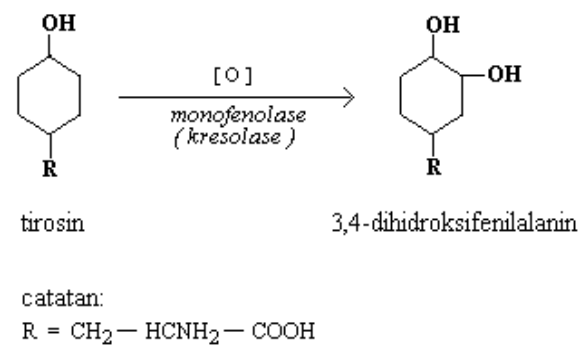

\section{Gambar 7-10: Oksidasi monofenol}

\section{b. OKSIDASE}

Oksidasi atau catecholase activity terjadi pada senyawa fenol dengan kandungan gugus hidroksil sebanyak dua buah disebut difenol, misalnya katekol. Reaksi ini akan menghasilkan ortoquinon. Gambar 7-11 memberi ilustrasi tentang reaksi katekol (orto-difenol) oleh ensim polifenoloksidase atau katekolase atau polifenolase dengan hasil berupa orto-quinon.

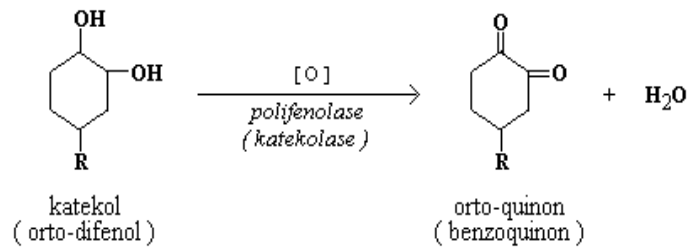

\section{Gambar 7-11: Oksidasi difenol}

Polifenolase merupakan senyawa Cu-protein dengan berat molekul 25.000 - 35.000, mempunyai pH optimum denkat dengan 7 , relatif tahan terhadap pemanasan, tetapi inaktif pada 
pemanasan $100^{\circ} \mathrm{C}$ selama $2-10$ menit. Pada teh substrat yang dominan adalah katekin, setelah mengalami oksidasi akan menghasilkan theaflavin yang berwarna oranye. Pada pisang substrat yang dominan adalah 3,4-dihidroksifeniletilamin suatu fenol yang mengandung nitrogen.

Perbedaan dari kedua reaksi tersebut yaitu terletak pada substratnya. Untuk reaksi hidroksilasi menggunakan substrat monofenol, sedangkan untuk reaksi oksidasi menggunakan substrat difenol. Urutan reaksi pencoklatan ensimatis secara keseluruhan antara lain tahap awal terjadi absorbsi oksigen yang sering juga terbentuk $\mathrm{CO}_{2}$. Selanjutnya terjadi oksidasi secara nonensimatis terhadap monofenol oleh orto-quinon, di samping juga adanya aktivitas ensim kresolase menghasilkan polifenol. Kemudian polifenol oleh ensim polifenoloksidase akan diubah secara oksidatif menjadi orto-quinon.

Tahap berikutnya terjadi polimerisasi atau kondensasi ortoquinon membentuk melanin, yaitu pigmen berwarna merahungu-coklat-hitam.

\subsubsection{PENCEGAHAN PENCOKLATAN ENSIMATIS}

Pencoklatan ensimatis akan terjadi apabila terdapat tiga faktor, yaitu substrat, ensim, dan oksigen. Substrat berupa senyawa fenol, dan ensim yang aktif adalah fenoloksidase.

\section{a. SUBSTRAT}

Secara teoretis pencegahan pencoklatan adalah melakukan transformasi pada substrat menjadi derivatnya sehingga akan mengurangi kemungkinan terjadinya pencoklatan. Misalnya dengan cara metilasi pada orto-difenol menjadi metil eter orto- 
difenol yang lebih tahan terhadap reaksi oksidasi daripada ortodifenol. Cara yang sering dilakukan adalah dengan metilasi.

Berdasarkan teori tersebut, Finkle kemudian mengusulkan cara pencegahan pencoklatan melalui metilasi pada polifenol dengan menggunakan ensim orto-metiltransferase. Mekanisme reaksi metilasi diilustrasikan pada Gambar 7-12.

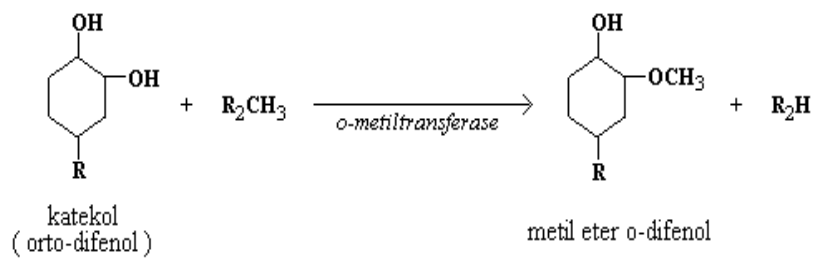

\section{Gambar 7-12: Metilasi difenol}

Dalam praktik buah-buahan dan sayuran dimaserasi dalam larutan yang mengandung orto- metil-transferase dan donor metil yang cocok misalnya derivat metionin, serta larutannya dibuat sedikit alkalis.

\section{b. ENSIM}

Metode umum yang digunakan untuk pencoklatan ensimatis adalah dengan memperlakukan ensim dan oksigen. Prinsip pendekatannya antara lain inaktivasi ensim, membuat kondisi yang tidak cocok dengan aktivitas ensim, memperkecil kontak dengan oksigen, dan menggunakan antioksidan.

\section{1). INAKTIVASI ENSIM}

Perlakuan panas dapat digunakan untuk inaktivasi ensim fenolase. Metode yang umum digunakan adalah perlakuan blanching, misalnya buah atau sayuran diperlakukan dengan air panas atau uap panas sampai 
ensim menjadi inaktif. Perlakuan panas ini akan mengakibatkan kesegaran menurun, demikian pula tekstur dan flavor menjadi kurang disukai daripada yang masih segar.

\section{2). PENURUNAN PH}

Fenolase dalam makanan mempunyai $\mathrm{pH}$ optimum 7, penurunan $\mathrm{pH}$ di bawah 4 akan memperlambat aktivitas fenolase. Asam sitrat banyak digunakan untuk menurunkan $\mathrm{pH}$ ini, meskipun sebenarnya asam malat lebih efektif dibandingkan dengan asam sitrat. Caranya yaitu buah-buahan atau sayuran dicelupkan ke dalam larutan asam sitrat atau menambahkannya langsung ke dalam sari buah, puree, dan sebagainya.

\section{3). ASAM ASKORBAT}

Asam askorbat atau isomernya seperti iso-asam askorbat dapat memperlambat pencoklatan ensimatis. Asam askorbat akan mereduksi orto-quinon kembali menjadi senyawa asal, yaitu orto-difenol. Dalam industri buah-buahan beku, asam askorbat sering digunakan bersama-sama dengan asam sitrat untuk menghalangi proses pencoklatan. Substansi perdeuksi lainnya seperti senyawa yang menghasilkan gugus -SH ternyata juga dapat mencegah pencoklatan ensimatis dengan cara mereduksi orto-quinon.

\section{4). PENGGUNAANSO2}

Sulfur dioksida, sulfit, dan bisulfit sangat efektif digunakan untuk mencegah pencoklatan ensimatis. 
ketiga senyawa tersebut dapat digunakan pada konsentrasi sangat rendah,misalnya $\mathrm{SO}_{2}$-bebas hanya memerlukan beberapa ppm (part per million) saja. Sulfur dioksida dan sulfit selain banyak digunakan dalam proses pengolahan buah-buahan juga sebagai pengawet dalam menguliti dan pemotongan kentang. Seperti asam askorbat, maka sulfur dioksida juga dapat mereduksi orto-quinon.Menurut Ponting (1960) Na-bisulfit, $\mathrm{Na}$-sulfit, $\mathrm{SO}_{2}$, dan Na-metabisulfit dapat mencegah fenolase. Zat-zat tersebut dapat dipakai dalam bentuk gas $\mathrm{SO}_{2}$ atau larutan sulfit. Penggunaan $\mathrm{SO}_{2}$ sebanyak 1-ppm dapat menghambat fenolase sebanyak 20\% dan penggunaan 10-ppm dapat menghambat semua fenolase.

Keuntungan penggunaan sulfit antara lain tidak mengubah (tekstur, flavor, bau) karena tidakmemerlukan panas, bersifat antiseptis, melindungi kerusakan vitamin C, bekerja efektif sebagai inhibitor, harganya murah.

Kerugian penggunaan $\mathrm{SO}_{2}$ antara lain memberikan bau dan flavor tertentu, memucatkan warna, misalnya pigmen antosianin, mempercepat korosi kaleng, beracun pada dosis tinggi, bersifat merusak vitamin $\mathrm{B}_{1}$.

\section{5). PENGGUNAANGARAM}

Garam umumnya digunakan untuk sayuran dan buahbuahan dengan cara segera merendamnya setelah dikupas dan dipotong ke dalam larutan $\mathrm{NaCl}$, cara ini dapat menghambat pencoklatan. Penggunaan pada kadar 0,1\% sudah cukup dapat menghambat pencoklatan. 


\section{c. OKSIGEN}

Mencegah bahan kontak dengan oksigen merupakan cara yang efisien untuk mencegah pencoklatan oksidatif. Contohnya untuk produk apokat, apabila inaktivasi ensim dengan panas akan menyebabkan timbul rasa pahit, apabila disimpan dalam almari pendingin menyebabkan timbul warna gelap pada permukaan yang terbuka, apabila dilakukan penurunan $\mathrm{pH}$ akan menyebabkan flavor yang tidak disukai. Oleh karena itu, pengepakan bersamaan dengan menggunakan nitrogen dapat mencegah perubahan warna pada permukaan. Cara lain dengan pengepakan hampa udara atau menggunakan larutan gula agar bahan tidak kontak dengan udara atau oksigen.[] 



\section{DAFTRR PUSTAKR}

Lillian Hoagland Meyer. 1973. Food Chemistry. New Delhi: Affiliated East-West Press Pvt. Ltd.

L.W. Aurand and A.E. Woods. 1973. Food Chemistry. Westport, Connecticut: The AVI Publishing Company, Inc.

David W. Martin, Jr., Peter A. Mayes, Victor W. Rodwell, Daryl K. Granner. 1985. Biokimia Harper's Review of Biochemistry (alih bahasa: Iyan Darmawan). Jakarta: ECC Penerbit Buku Kedokteran.

Peter N. Cambell and Anthony D. Smith. 1988. Biochemistry Illustrated. New York: Churchill Livingstone.

Z. Berk. 1976. Introduction to The Biochemsitry of Foods. New York: Elesevier Scientific Company.

K.A. Buckle, R.A. Edwards, G.H. Fleet, M.Wooton. 1985. Food Science (Ilmu Pangan, terjemahan: Hari Purnomo dan Adiono). Jakarta: UI-Press. 
